National Water-Quality Assessment Program

Ground-Water Quality of the Northern High Plains Aquifer, 1997, 2002-04

Scientific Investigations Report 2006-5138 


\section{National Water-Quality Assessment Program \\ Ground-Water Quality of the Northern High Plains Aquifer, 1997, 2002-04}

By Jennifer S. Stanton and Sharon L. Qi

Scientific Investigations Report 2006-5138 


\section{U.S. Department of the Interior DIRK KEMPTHORNE, Secretary}

\section{U.S. Geological Survey \\ Mark D. Myers, Director}

\section{U.S. Geological Survey, Reston, Virginia: 2007}

For product and ordering information:

World Wide Web: http://www.usgs.gov/pubprod

Telephone: 1-888-ASK-USGS

For more information on the USGS--the Federal source for science about the Earth, its natural and living resources, natural hazards, and the environment:

World Wide Web: http://www.usgs.gov

Telephone: 1-888-ASK-USGS

Any use of trade, product, or firm names is for descriptive purposes only and does not imply endorsement by the U.S. Government.

Although this report is in the public domain, permission must be secured from the individual copyright owners to reproduce any copyrighted materials contained within this report.

Suggested citation:

Stanton, J.S., and Qi, S.L., 2007, Ground-water quality of the northern High Plains aquifer, 1997, 2002-04: U.S. Geological Survey Scientific Investigations Report 2006-5138, 60 p. 


\section{Foreword}

The U.S. Geological Survey (USGS) is committed to serve the Nation with accurate and timely scientific information that helps enhance and protect the overall quality of life and facilitates effective management of water, biological, energy, and mineral resources (http://www.usgs. gov/). Information on the quality of the Nation's water resources is of critical interest to the USGS because it is so integrally linked to the long-term availability of water that is clean and safe for drinking and recreation and that is suitable for industry, irrigation, and habitat for fish and wildlife. Escalating population growth and increasing demands for multiple water uses make water availability, now measured in terms of quantity and quality, even more critical to the long-term sustainability of our communities and ecosystems.

The USGS implemented the National Water-Quality Assessment (NAWQA) Program to support national, regional, and local information needs and decisions related to water-quality management and policy (http://water.usgs.gov/nawqa/). Shaped by and coordinated with ongoing efforts of other Federal, State, and local agencies, the NAWQA Program is designed to answer: What is the condition of our Nation's streams and ground water? How are the conditions changing over time? How do natural features and human activities affect the quality of streams and ground water, and where are those effects most pronounced? By combining information on water chemistry, physical characteristics, stream habitat, and aquatic life, the NAWQA Program aims to provide science-based insights for current and emerging water issues and priorities. NAWQA results can contribute to informed decisions that result in practical and effective waterresource management and strategies that protect and restore water quality.

Since 1991, the NAWQA Program has implemented interdisciplinary assessments in more than 50 of the Nation's most important river basins and aquifers, referred to as Study Units (http://water.usgs.gov/nawqa/nawqamap.htm/). Collectively, these Study Units account for more than 60 percent of the overall water use and population served by public water supply and are representative of the Nation's major hydrologic landscapes, priority ecological resources, and agricultural, urban, and natural sources of contamination.

Each assessment is guided by a nationally consistent study design and methods of sampling and analysis. The assessments thereby build local knowledge about water-quality issues and trends in a particular stream or aquifer while providing an understanding of how and why water quality varies regionally and nationally. The consistent, multiscale approach helps to determine if certain types of water-quality issues are isolated or pervasive and allows direct comparisons of how human activities and natural processes affect water quality and ecological health in the Nation's diverse geographic and environmental settings. Comprehensive assessments on pesticides, nutrients, volatile organic compounds, trace metals, and aquatic ecology are developed at the national scale through comparative analysis of the Study-Unit findings (http://water.usgs.gov/nawqa/natsyn.htm).

The USGS places high value on the communication and dissemination of credible, timely, and relevant science so that the most recent and available knowledge about water resources can be applied in management and policy decisions. We hope this NAWQA publication will provide you the needed insights and information to meet your needs and thereby foster increased awareness and involvement in the protection and restoration of our Nation's waters. 
The NAWQA Program recognizes that a national assessment by a single program cannot address all water-resource issues of interest. External coordination at all levels is critical for a fully integrated understanding of watersheds and for cost-effective management, regulation, and conservation of our Nation's water resources. The Program, therefore, depends extensively on the advice, cooperation, and information from other Federal, State, interstate, Tribal, and local agencies, nongovernment organizations, industry, academia, and other stakeholder groups. The assistance and suggestions of all are greatly appreciated.

Robert M. Hirsch Associate Director for Water 


\section{Contents}

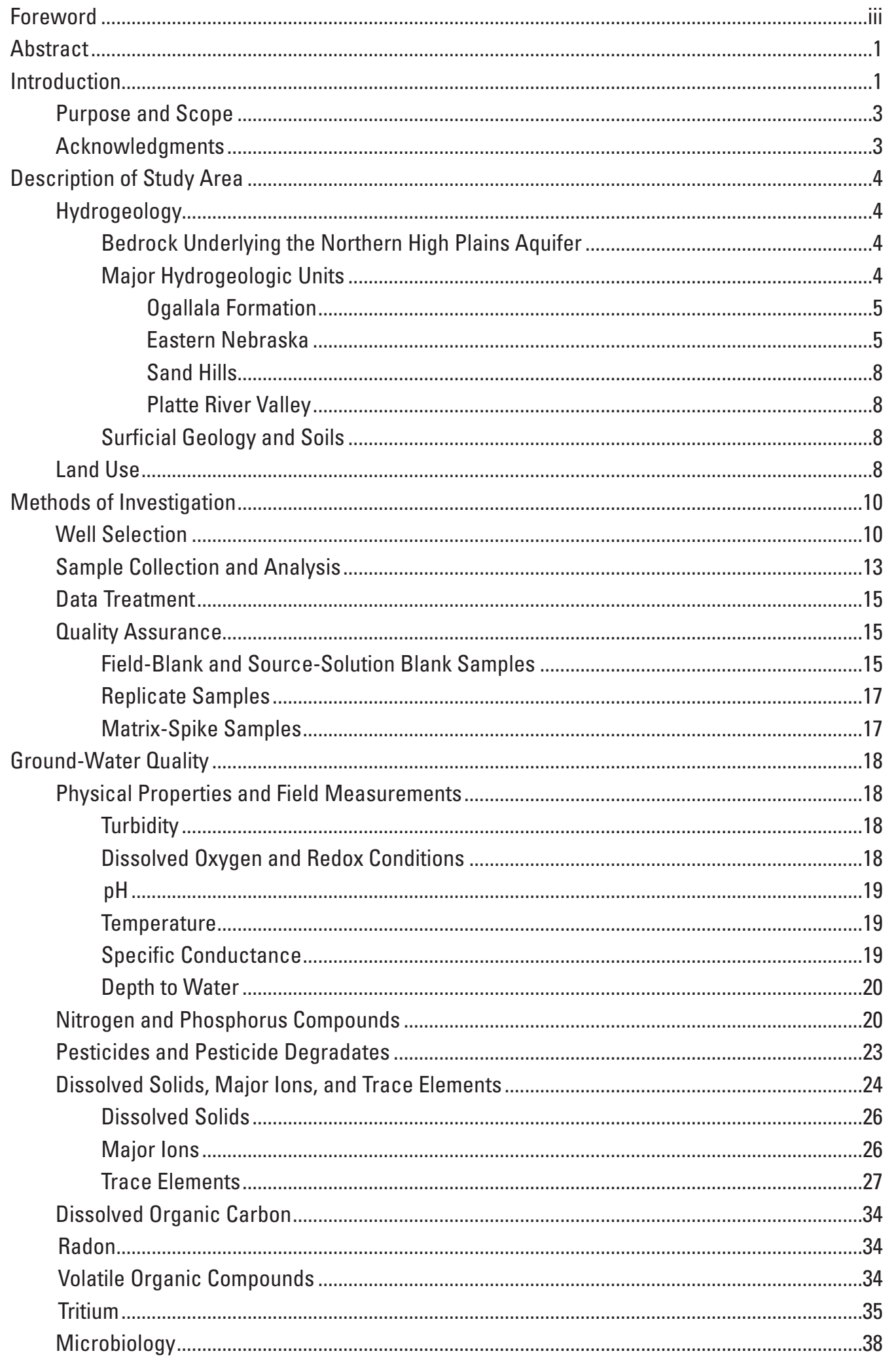


Relation Between Hydrogeologic and Land-Use Variables and Ground-Water Quality ................38

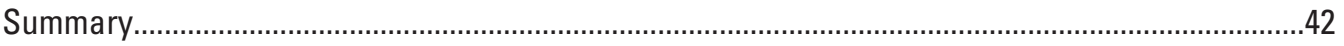

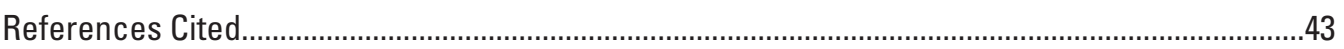

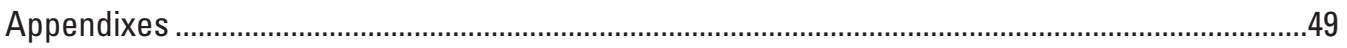

1. Selected well-construction information for wells samples in the northern High Plains aquifer, 1997, 2002-04 ..........................................................................51

2. Pesticides analyzed in ground-water samples collected from the northern High Plains aquifer, 1997, 2002-04 ..........................................................................55

3. Volatile organic compounds analyzed in ground-water samples collected from the northern High Plains aquifer, 1997, 2002-04................................................58

4. Description of CD-ROM contents .........................................................................60

\section{CD-ROM}

[In pocket]

Northern High Plains Ground-Water Quality database. (The data are provided in MS Access format and in ASCII flat file format.)

\section{Figures}

1-3. Maps showing:

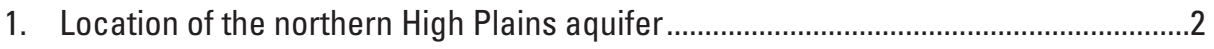

2. Bedrock units underlying the northern High Plains aquifer .......................................5

3. Location of major hydrogeologic units and trace of generalized geologic section $A-A^{\prime}$.

4. Geologic section $A-A^{\prime}$ in the High Plains aquifer and underlying bedrock......................

5-7. Maps showing:

5. Permeability of soils overlying the northern High Plains aquifer ..............................

6. Land use in the northern High Plains, nominal 1992 ...........................................10

7. Percentage of cropland, percentage of irrigated cropland, and average pounds of nitrogen applied per acre of cropland in the northern High Plains.

8. Map and graph showing distribution of nitrate concentrations by hydrogeologic unit in the northern High Plains aquifer, 1997, 2002-04

9. Graph showing pesticide compound concentrations in the northern High Plains aquifer, 1997, 2002-04.

10. Map and graph showing distribution of pesticide detections by hydrogeologic unit in the northern High Plains aquifer, 1997, 2002-04

11. Trilinear diagrams showing the relations between compositions of major ions in water by hydrogeologic unit in the northern High Plains aquifer, 1997, 2002-04.

12. Trilinear diagrams showing the relations between compositions of major ions at sites affected by agricultural activities, sites unaffected by agricultural activities, and sites not known to be affected by agricultural activities in the northern High Plains aquifer, 1997, 2002-04

13. Trilinear diagrams showing the relations between compositions of major ions in samples collected from the Platte River Valley Quaternary unit and samples collected from the Platte River.... 
14. Map and graph showing distribution of arsenic concentrations by hydrogeologic unit in the northern High Plains aquifer, 1997, 2002-04

15. Map and graph showing distribution of uranium concentrations by hydrogeologic unit in the northern High Plains aquifer, 1997, 2002-04

16. Graph showing volatile organic compound (VOC) concentrations in the northern High Plains aquifer, 1997, 2002-04

17. Map and graph showing distribution of volatile organic compound (VOC) detections by hydrogeologic unit in the northern High Plains aquifer, 1997, 2002-04

18. Graphs showing distribution of nitrate concentrations, pesticide detections, volatile organic compound (VOC) detections, and tritium concentrations relative to depth below the water table in the northern High Plains aquifer, 1997, 2002-04

19. Map and graph showing distribution of samples containing water recharged in the last 50 years by hydrogeologic unit in the northern High Plains aquifer, 1997, 2002-04

\section{Tables}

1. Summary of selected hydrogeologic and land-use characteristics of four major hydrogeologic units of the northern High Plains aquifer ...............................................4

2. Land use overlying four hydrogeologic units in the northern High Plains, 1992 ..............11

3. Estimated application rates of nitrogen and 10 most commonly applied pesticides ......11

4. Laboratory analysis and field preservation methods for measured water-quality constituents in the northern High Plains, 1997, 2002-04.

5. Constituents detected in field-blank samples collected in the northern High Plains 1997, 2002-04

6. Summary of relative percent differences for replicate samples and percent recoveries for field matrix-spike samples collected in the northern High Plains, 1997, 2002-04.

7. Median values for physical properties, water levels, and depths of well screen in the northern High Plains aquifer, 1997, 2002-04.

8. Median concentrations of nitrogen and phosphorus compounds in the northern High Plains aquifer, 1997, 2002-04

9. Median concentrations of major ions, trace elements, dissolved organic carbon, and radon in the northern High Plains aquifer, 1997, 2002-04 


\section{Conversion Factors}

\begin{tabular}{|c|c|c|}
\hline Multiply & By & To obtain \\
\hline \multicolumn{3}{|c|}{ Length } \\
\hline foot (ft) & 0.3048 & meter $(\mathrm{m})$ \\
\hline mile (mi) & 1.609 & kilometer $(\mathrm{km})$ \\
\hline \multicolumn{3}{|c|}{ Area } \\
\hline acre & 4,047 & square meter $\left(\mathrm{m}^{2}\right)$ \\
\hline square mile $\left(\mathrm{mi}^{2}\right)$ & 2.590 & square kilometer $\left(\mathrm{km}^{2}\right)$ \\
\hline \multicolumn{3}{|c|}{ Volume } \\
\hline gallon (gal) & 0.003785 & cubic meter $\left(\mathrm{m}^{3}\right)$ \\
\hline acre-foot (acre-ft) & 1,233 & cubic meter $\left(\mathrm{m}^{3}\right)$ \\
\hline \multicolumn{3}{|c|}{ Flow rate } \\
\hline gallon per minute (gal/min) & 0.06309 & liter per second (L/s) \\
\hline inch per year (in/yr) & $\begin{array}{l}25.4 \\
\quad \text { Mass }\end{array}$ & millimeter per year $(\mathrm{mm} / \mathrm{yr})$ \\
\hline pound (lb) & 0.4536 & kilogram $(\mathrm{kg})$ \\
\hline \multicolumn{3}{|c|}{ Radioactivity } \\
\hline picocurie per liter $(\mathrm{pCi} / \mathrm{L})$ & 0.312 & tritium unit \\
\hline \multicolumn{3}{|c|}{ Hydraulic conductivity } \\
\hline foot per day (ft/d) & 0.3048 & meter per day $(\mathrm{m} / \mathrm{d})$ \\
\hline \multicolumn{3}{|c|}{ Application rate } \\
\hline pounds per acre per year [(lb/acre)/yr] & 1.121 & kilograms per hectare per year $[(\mathrm{kg} / \mathrm{ha}) / \mathrm{yr}]$ \\
\hline \multicolumn{3}{|c|}{ Concentration } \\
\hline microgram per liter $(\mu \mathrm{g} / \mathrm{L})$ & 1 & part per billion \\
\hline milligram per liter $(\mathrm{mg} / \mathrm{L})$ & 1 & part per million \\
\hline milligram per liter $(\mathrm{mg} / \mathrm{L})$ & 0.058 & grain per gallon \\
\hline
\end{tabular}

Temperature in degrees Celsius $\left({ }^{\circ} \mathrm{C}\right)$ may be converted to degrees Fahrenheit $\left({ }^{\circ} \mathrm{F}\right)$ as follows:

${ }^{\circ} \mathrm{F}=\left(1.8 \mathrm{x}^{\circ} \mathrm{C}\right)+32$

Temperature in degrees Fahrenheit $\left({ }^{\circ} \mathrm{F}\right)$ may be converted to degrees Celsius $\left({ }^{\circ} \mathrm{C}\right)$ as follows:

$$
{ }^{\circ} \mathrm{C}=\left({ }^{\circ} \mathrm{F}-32\right) / 1.8
$$

Vertical coordinate information is referenced to the National Geodetic Vertical Datum of 1929 (NGVD 1929).

Horizontal coordinate information is referenced to the North American Datum of 1983 (NAD 83). 


\title{
Ground-Water Quality of the Northern High Plains Aquifer, 1997, 2002-04
}

\author{
By Jennifer S. Stanton and Sharon L. Qi
}

\section{Abstract}

An assessment of ground-water quality in the northern High Plains aquifer was completed during 1997 and 2002-04. Ground-water samples were collected at 192 low-capacity, primarily domestic wells in four major hydrogeologic units of the northern High Plains aquifer-Ogallala Formation, Eastern Nebraska, Sand Hills, and Platte River Valley. Each well was sampled once, and water samples were analyzed for physical properties and concentrations of nitrogen and phosphorus compounds, pesticides and pesticide degradates, dissolved solids, major ions, trace elements, dissolved organic carbon (DOC), radon, and volatile organic compounds (VOCs). Tritium and microbiology were analyzed at selected sites. The results of this assessment were used to determine the current water-quality conditions in this subregion of the High Plains aquifer and to relate ground-water quality to natural and human factors affecting water quality.

Water-quality analyses indicated that water samples rarely exceeded established U.S. Environmental Protection Agency public drinking-water standards for those constituents sampled; 13 of the constituents measured or analyzed exceeded their respective standards in at least one sample. The constituents that most often failed to meet drinking-water standards were dissolved solids (13 percent of samples exceeded the U.S. Environmental Protection Agency Secondary DrinkingWater Regulation) and arsenic (8 percent of samples exceeded the U.S. Environmental Protection Agency Maximum Contaminant Level). Nitrate, uranium, iron, and manganese concentrations were larger than drinking-water standards in 6 percent of the samples.

Ground-water chemistry varied among hydrogeologic units. Wells sampled in the Platte River Valley and Eastern Nebraska units exceeded water-quality standards more often than the Ogallala Formation and Sand Hills units. Thirty-one percent of the samples collected in the Platte River Valley unit had nitrate concentrations greater than the standard, 22 percent exceeded the manganese standard, 19 percent exceeded the sulfate standard, 26 percent exceeded the uranium standard, and 38 percent exceeded the dissolved-solids standard. In addition, 78 percent of samples had at least one detectable pesticide and 22 percent of samples had at least one detectable VOC. In the Eastern
Nebraska unit, 30 percent of the samples collected had dissolved-solids concentrations larger than the standard, 23 percent exceeded the iron standard, 13 percent exceeded the manganese standard, 10 percent exceeded the arsenic standard, 7 percent exceeded the sulfate standard, 7 percent exceeded the uranium standard, and 7 percent exceeded the selenium standard. No samples exceeded the nitrate standard. Thirty percent of samples had at least one detectable pesticide compound and 10 percent of samples had at least one detectable VOC. In contrast, the Sand Hills and Ogallala Formation units had fewer detections of anthropogenic compounds and drinking-water exceedances. In the Sand Hills unit, 15 percent of the samples exceeded the arsenic standard, 4 percent exceeded the nitrate standard, 4 percent exceeded the uranium standard, 4 percent exceeded the iron standard, and 4 percent exceeded the dissolved-solids standard. Fifteen percent of samples had at least one pesticide compound detected and 4 percent had at least one VOC detected. In the Ogallala Formation unit, 6 percent of water samples exceeded the arsenic standard, 4 percent exceeded the dissolved-solids standard, 3 percent exceeded the nitrate standard, 2 percent exceeded the manganese standard, 1 percent exceeded the iron standard, 1 percent exceeded the sulfate standard, and 1 percent exceeded the uranium standard. Eight percent of samples collected in the Ogallala Formation unit had at least one pesticide detected and 6 percent had at least one VOC detected. Differences in ground-water chemistry among the hydrogeologic units were attributed to variable depth to water, depth of the well screen below the water table, reductionoxidation conditions, ground-water residence time, interactions with surface water, composition of aquifer sediments, extent of cropland, extent of irrigated land, and fertilizer application rates.

\section{Introduction}

The High Plains aquifer is a nationally important water resource. It underlies about $174,400 \mathrm{mi}^{2}$ in parts of eight Western States (fig. 1) and is the primary water supply for drinking water, irrigation, animal production, and industry in the region. About 27 percent of agricultural land in the Nation is in the High Plains region, and about 30 percent 


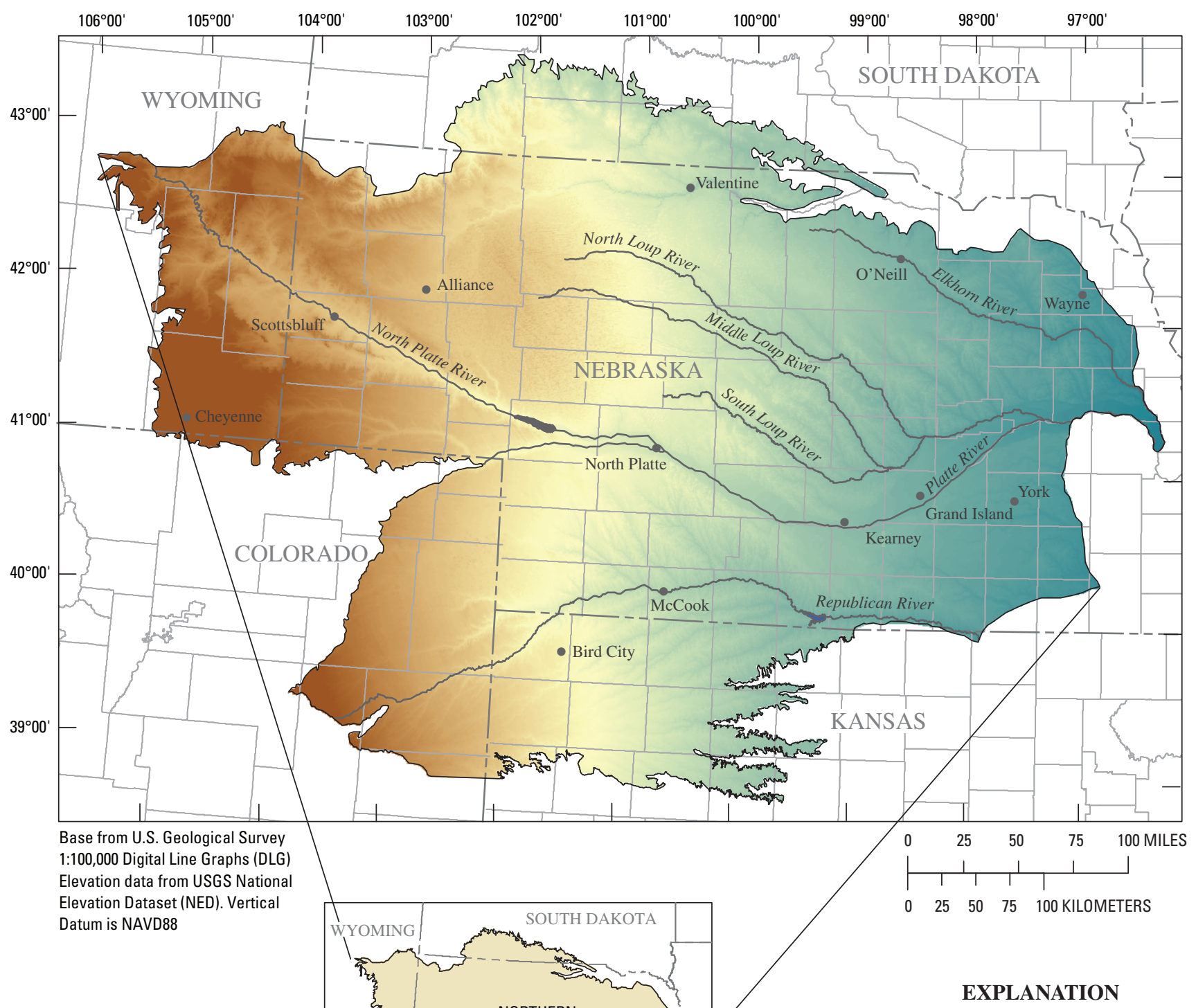

Land surface elevation, in feet

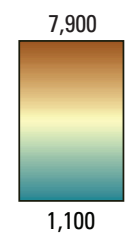

Figure 1. Location of the northern High Plains aquifer. 
of ground water pumped for irrigation in the United States is pumped from the High Plains aquifer (Dennehy, 2000). In 2000, the High Plains aquifer supplied drinking water to 1.9 million people, or about 82 percent of the High Plains population (Sharon Qi, U.S. Geological Survey, written commun., 2005).

Previous ground-water-quality studies provide a wealth of local information but lack consistent analytical methodology or continuity across political boundaries. These local studies of water quality provided nitrate and major-ion data across many parts of the High Plains aquifer and indicated that the quality of water in the aquifer is generally adequate for irrigation purposes; however, several constituents exceeded the U.S. Environmental Protection Agency's drinking-water standards in some samples (Litke, 2001). Historical water-quality information for trace elements, pesticides, volatile organic compounds (VOCs), and bacteria were generally lacking in many parts of the High Plains aquifer.

In 1991, the U.S. Geological Survey (USGS) implemented the National Water-Quality Assessment (NAWQA) Program to provide scientifically sound information for managing the Nation's water resources. The goals of the NAWQA Program are to assess the chemical, physical, and biological status of the Nation's surface- and ground-water resources, identify long-term trends in these conditions, and identify the natural and human factors that affect water quality (Gilliom and others, 2001). The program is designed to collect and analyze data so long-term water-quality information describing the condition of surface- and ground-water resources is consistent and comparable across the Nation. To satisfy the goal of assessing the occurrence and distribution of water-quality constituents of regionally important aquifer systems, the NAWQA Program conducted the High Plains Regional Ground-Water Study. By studying the aquifer using the program's consistent design and sampling and analytical methods, data are comparable across the extent of the High Plains study area.

For logistical purposes, during the High Plains Regional Ground-Water study, the High Plains aquifer was subdivided into three geographic subregions (fig. 1)—northern High Plains, central High Plains, and southern High Plains. The focus of this report is the northern High Plains subregion. Water-quality information for the central and southern High Plains regions has been described by Fahlquist (2003) and Becker and others (2002). The northern High Plains aquifer is composed of five major hydraulically connected units of different ages and lithologies_-Brule and Arikaree Formations, Ogallala Formation, Eastern Nebraska, Sand Hills, and Platte River Valley (Gutentag and others, 1984). Historical ground-water quality data indicate large variations in water quality among these hydrogeologic units (Litke, 2001). This report describes water-quality conditions in hydrogeologic units and considers the unique hydrogeologic and land-use characteristics of each unit in relation to observed water-quality conditions. Results for respective hydrogeologic units are compared to understand factors that affect groundwater quality.

\section{Purpose and Scope}

This report describes the ground-water quality of the northern High Plains aquifer in parts of Colorado, Kansas, Nebraska, South Dakota, and Wyoming (fig. 1). Water samples were collected between 2002 and 2004 from three principal hydrogeologic units of the northern High Plains aquiferOgallala Formation (108 samples), Eastern Nebraska (30 samples), and Sand Hills (27 samples). Water-quality samples were not collected from the Brule and Arikaree Formations or the Platte River Valley units due to financial constraints. However, 27 samples were collected from the Platte River Valley in 1997 as part of an earlier NAWQA Program study and are included in this report.

Water was collected from low-capacity (primarily domestic water-supply) wells and analyzed for physical properties and concentrations of nitrogen and phosphorus compounds, pesticides and pesticide degradates, dissolved solids, major ions, trace elements, dissolved organic carbon (DOC), radon, and VOCs at all sites. Microbiology and tritium were analyzed at selected sites. The relation between ground-water quality and hydrogeologic and land-use variables in the study area was examined.

\section{Acknowledgments}

The author thanks the landowners that allowed access to their private wells. Without their cooperation, this study would not have been possible. The many well drillers that provided well-construction information for domestic wells are gratefully acknowledged. The author also thanks Jim Goeke, Sue Olafsen-Lacke, Steve Sibray, Scott Summerside, and Frank Smith of the Nebraska Conservation and Survey Division of the University of Nebraska, and Jim Cannia of the Nebraska Department of Natural Resources for their help with interpreting well-borehole logs and sharing their knowledge of local hydrogeology. The author thanks USGS employees for their assistance with sample collection and data management: Tim Boyle, Virginia McGuire, and Jackson Currie in Nebraska; Jeffrey Bails, Jason Gurdak, and Pete Striffler in Colorado; and Caleb Cope and Martin Schneider in Oklahoma. Thanks to the following reviewers and editors for their contributions to this manuscript: Mary Kidd, Matthew Landon, Kathleen Neitzert of the U.S. Geological Survey; Jim Cannia of the Nebraska Department of Natural Resources; and Jim Goeke of the Conservation and Survey Division of the University of Nebraska. 


\section{Description of Study Area}

\section{Hydrogeology}

The hydrogeologic characteristics of an aquifer can strongly affect water quality. The minerals and elements that make up aquifer sediments will dissolve over time and determine dissolved-solids, major-ion, and trace-element concentrations. Organic matter in an aquifer can influence reduction-oxidation processes, which in turn, can affect inorganic constituents such as dissolved arsenic, iron, manganese, nitrate, sulfate, uranium, and organic compounds such as pesticides and VOCs. The particle sizes of sediments of an aquifer affect the rate of water flow. Water moves more easily through the pore spaces of sediments with larger particles, such as gravels, than it does through sediments with small particles, such as clays. The depositional environment will affect the sorting of sediment sizes in an aquifer. For example, the generally poorly sorted sediments from glacial deposition have many different sizes. In this case, smaller particles tend to fill the voids between larger particles and inhibit water flow. The depositional environment can create geologic layers of limited permeability in an aquifer that inhibit the transport of water and chemicals from shallow deposits to deep deposits. As depth to water increases, the risk of ground-water contamination from human sources typically decreases. Hydrogeologic characteristics as determined from previous studies differ between the four major units in the northern High Plains aquifer (table 1) (U.S. Department of Agriculture, 1994; Schwarz and Alexander, 1995; Sharon Qi, U.S. Geological Survey, written commun., 2005).

\section{Bedrock Underlying the Northern High Plains Aquifer}

The northern High Plains aquifer is underlain by bedrock formations of Tertiary age in the west and Cretaceousage deposits in the east (fig. 2) (Gutentag and others, 1984).
The Tertiary-age bedrock formations consist of the Chadron Formation and the Brule Formation of the White River Group where it is not fractured. These formations are composed of clay, silt, siltstone, and consolidated beds of volcanic ash, clay, and fine sand that were originally deposited in a freshwater environment. The Upper and Lower Cretaceous bedrock formations consist of shales, chalks, limestones, and sandstones that were deposited in a marine environment. These rocks contain higher concentrations of soluble minerals and elements and can influence the water chemistry of the overlying High Plains aquifer if water containing these dissolved minerals and elements moves up into the aquifer. Water can flow from bedrock into the aquifer when natural ground-water flow paths are from lower units to upper units or when pumping in the aquifer creates lower pressure in the aquifer, causing water to move from higher pressure in the bedrock to lower pressure in the aquifer (McMahon and others, 2004b).

\section{Major Hydrogeologic Units}

The High Plains aquifer consists of hydraulically connected geologic units from the late Tertiary through Quaternary geologic time periods (approximately 30 million years ago to near present time) (Gutentag and others, 1984). The principal water-bearing unit of the High Plains aquifer is the Ogallala Formation (OGAL). Sediments composing this unit were deposited approximately 5 to 19 million years ago. The High Plains aquifer also includes older deposits and younger deposits. Older deposits are in the Brule and Arikaree Formations (BRAK). The younger deposits in the northern High Plains can be divided into three significant sources of water-the Eastern Nebraska (EAST), Sand Hills (SAND), and Platte River Valley (PLAT) units. For summarizing water quality in this report, the northern High Plains aquifer has been divided into the five major hydrogeologic units: BRAK, OGAL, EAST, SAND, and PLAT (figs. 3 and 4). Samples were not collected from the BRAK.

Table 1. Summary of selected hydrogeologic and land-use characteristics of four major hydrogeologic units of the northern High Plains aquifer.

\begin{tabular}{|c|c|c|c|c|}
\hline & $\begin{array}{c}\text { Ogallala } \\
\text { Formation } \\
\text { (OGAL) }\end{array}$ & $\begin{array}{c}\text { Eastern } \\
\text { Nebraska } \\
\text { (EAST) }\end{array}$ & $\begin{array}{l}\text { Sand Hills } \\
\text { (SAND) }\end{array}$ & $\begin{array}{c}\text { Platte River } \\
\text { Valley } \\
\text { (PLAT) }\end{array}$ \\
\hline Median depth to ground water, in feet below land surface ${ }^{1}$ & 110 & 79 & 20 & 5 \\
\hline Average soil organic matter, in percent by weight ${ }^{2}$ & 0.54 & 0.90 & 0.40 & 0.74 \\
\hline Percentage of overlying land area used for cropland ${ }^{3}$ & 46 & 83 & 10 & 65 \\
\hline Percentage of overlying land area used for irrigated cropland ${ }^{4}$ & 10 & 34 & 5 & 37 \\
\hline
\end{tabular}

${ }^{1}$ Source: Sharon Qi, U.S. Geological Survey, written commun., 2005.

${ }^{2}$ Source: 1994 STATSGO data base (U.S. Department of Agriculture, 1994; Schwarz and Alexander, 1995).

${ }^{3}$ Source: U.S. Geological Survey, 1992.

${ }^{4}$ Source: Thelin and Heimes, 1987.

${ }^{5}$ Source: Kerie Hitt, U.S. Geological Survey, written commun., 2002. 


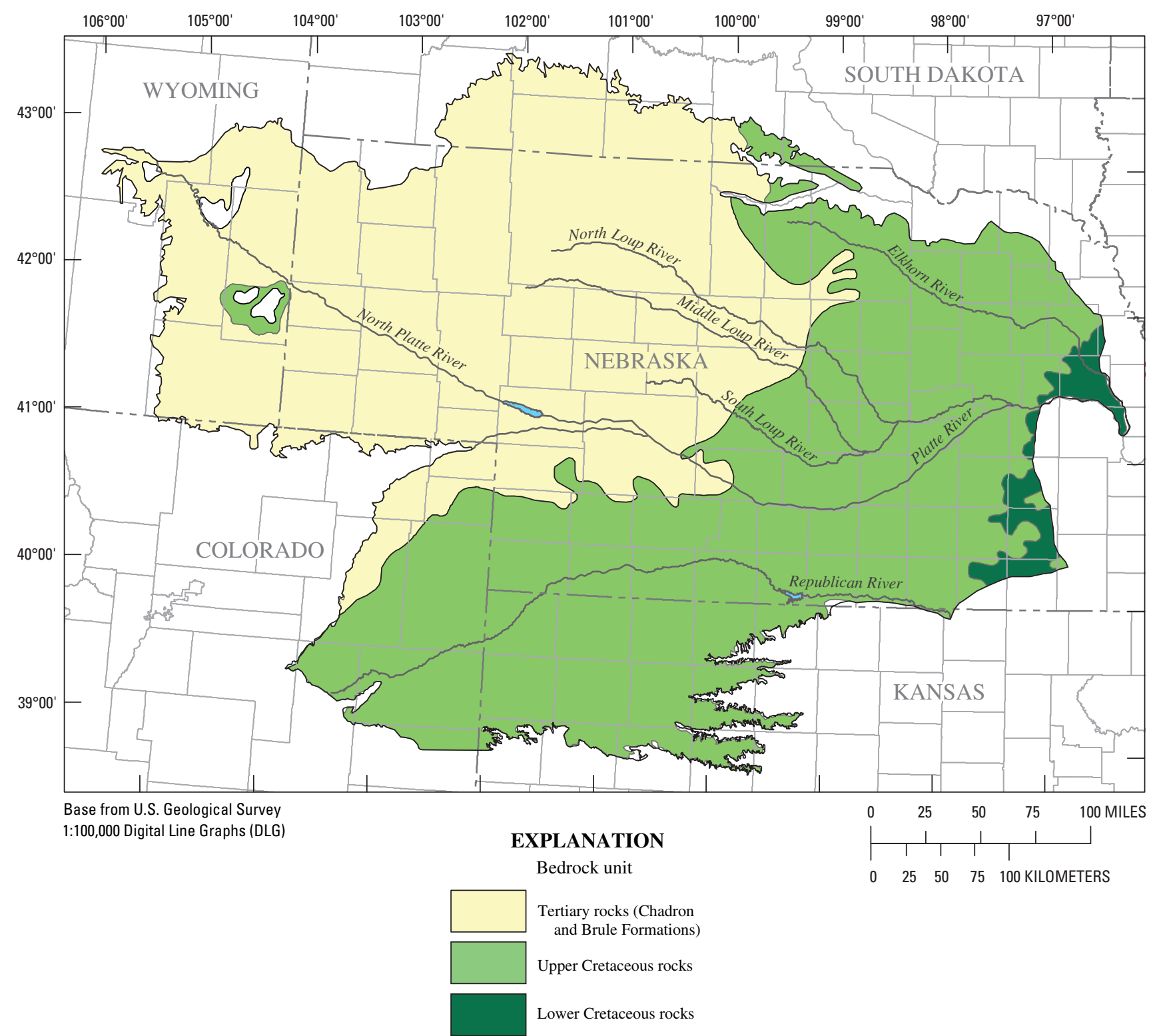

Figure 2. Bedrock units underlying the northern High Plains aquifer (modified from Gutentag and others, 1984).

\section{Ogallala Formation}

The High Plains aquifer is sometimes referred to as "the Ogallala aquifer" because the OGAL unit is the most areally extensive and the most plentiful source of ground water in the aquifer. This unit is the result of a major alluvial (river) depositional period that occurred during the Tertiary Miocene Epoch (between 5 and 19 million years ago). During this period, a system of braided streams deposited sediments that formed a complex "cut-and-fill" stratigraphy (Swinehart and others, 1985; Gutentag and others, 1984; Swinehart and Diffendal, 1989). The unit consists of unconsolidated sand, gravel, clay, and silt along with layers of calcium carbonate and siliceous cementation. In many areas, a zone of postdeposition cementation exists near the top of this unit, creating an erosion-resistant ledge. Periodic episodes of volcanic ash deposition also occurred during this period and created localized ash beds within the aquifer (Swinehart and others, 1985; Swinehart and Diffendal, 1997). The OGAL overlies the Chadron, Brule, and Arikaree Formations in the western part of the northern High Plains and marine Cretaceous rock in the eastern part of the northern High Plains. It underlies a variety of saturated and unsaturated materials across its extent.

\section{Eastern Nebraska}

For purposes of this report, the EAST unit refers to the late Tertiary (Pliocene) and Quaternary (Pleistocene) deposits in the eastern part of the northern High Plains where the OGAL is thin or absent. Sand and gravel originating from the west was deposited in valleys during the Pliocene period (2 to 5 million years ago) (Richmond and others, 1994; Gosselin 


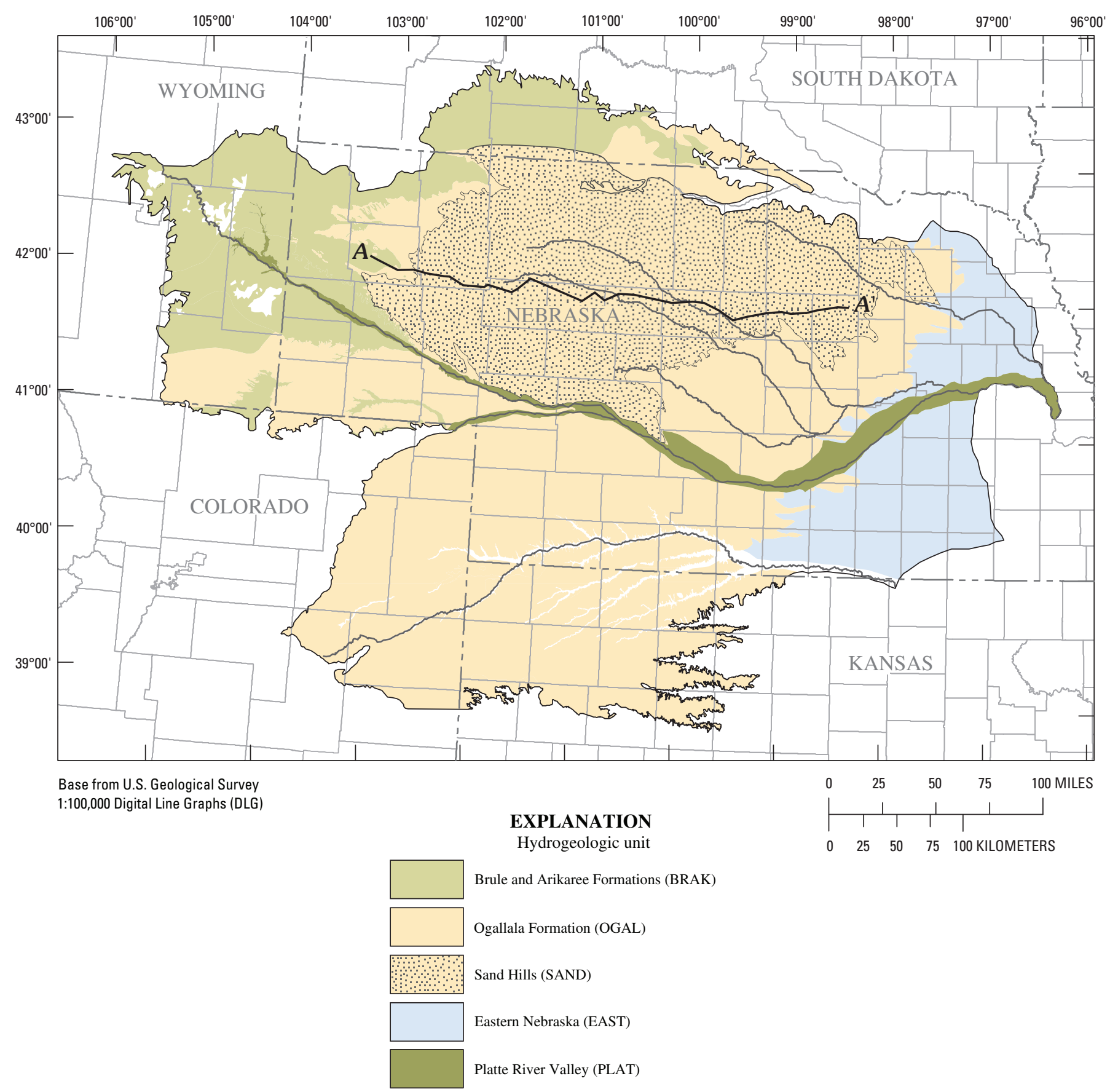

Figure 3. Location of major hydrogeologic units and trace of generalized geologic section $A-A^{\prime}$ (modified from Gutentag and others, 1984).

and others, 1996). These deposits contain weathering products derived from granite or anorthosite from the Laramie Range in Wyoming as well as some quartzite from the Medicine Bow Mountains (Richmond and others, 1994). Later, glacial processes during the Pleistocene period ( 0.01 to 2 million years ago) continued to fill valleys with coarse sand and gravel originating from the north (Gosselin and others, 1996). The EAST unit overlies either the OGAL where it is present or Cretaceous-age bedrock. It underlies unsaturated glacial till (a glacially deposited mixture of clay, sand, gravel, and stones of variable sizes) and loess (wind-deposited silt or clay, typically deposited during glacial periods). The glacial till contains iron sulfide and other minerals that can be sources of iron, manganese, sulfate, and calcium (Engberg and Spalding, 1978). Glacial till and loess can be relatively impermeable.

The sand and gravel deposits in paleovalleys provide the primary source of water for high-capacity wells. However, many low-capacity domestic and stock wells obtain water from lenses of perched or semiperched ground water (Gosselin and others, 1996). 

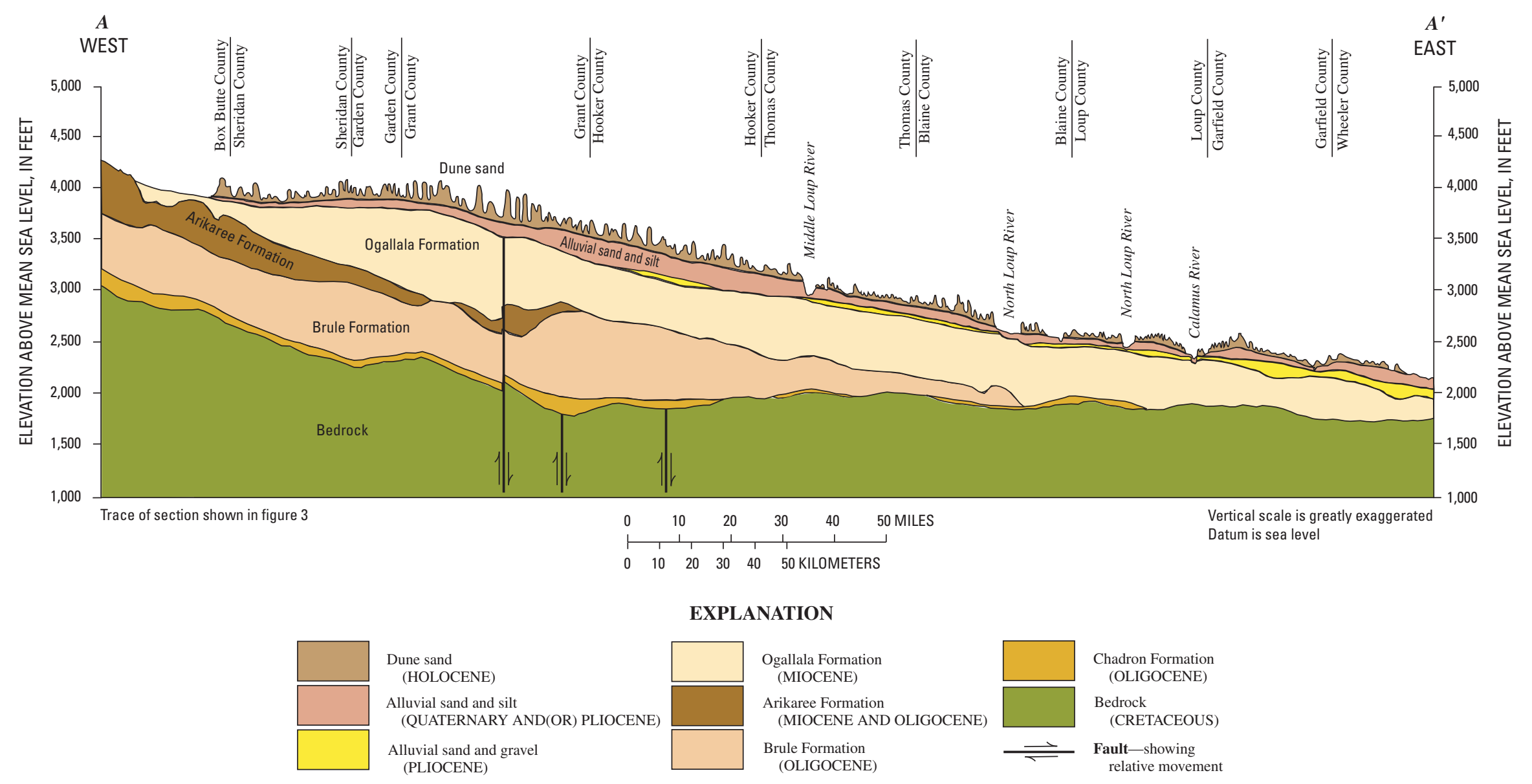

Figure 4. Geologic section $A-A^{\prime}$ in the High Plains aquifer and underlying bedrock (from Bleed and Flowerday, 1989). 


\section{Sand Hills}

The SAND unit includes Quaternary (Pleistocene and Holocene) and late Tertiary (Pliocene) deposits for purposes of this report. The sediments of the SAND unit are thought to have been deposited, or reworked, between about 5 million and 5 to 10 thousand years ago (Bleed and Flowerday, 1989). It is composed of river-deposited sand, silt, and gravel that originated from Colorado and Wyoming (Swinehart and Diffendal, 1989). The Pliocene deposits, primarily the Broadwater Formation, in this unit compose the most extensive layer of coarse-grained sediments in the northern High Plains (Jim Goeke, Conservation and Survey Division of the University of Nebraska, written commun., 2006). These sediments generally are the products of weathering of granite, anorthosite, or quartzite (Richmond and others, 1994). During the Pleistocene time period, few sediments accumulated. However, it is thought that erosion of the local geologic units (OGAL and younger deposits) occurred in the north and west parts of the unit. During the late Pleistocene and Holocene periods, climatic conditions caused the available sands to form into dunes (sand hills). Conditions eventually shifted again, allowing vegetation to stabilize the dunes into the grasscovered hills present today. This unit overlies the BRAK in the west and the OGAL in the east. Sand and(or) loess overlie this unit.

The Sand Hills region is one of the largest grassstabilized dune regions in the world. Its unique topography consists of dunes as high as $400 \mathrm{ft}$ and as long as $20 \mathrm{mi}$ (Bleed and Flowerday, 1989). The hydrology of this region is unlike the rest of the northern High Plains. The sandy soils have high infiltration rates, and precipitation rarely flows over the land surface. Surface water is almost entirely derived from groundwater discharge and, as a result, streamflows are steady and floods rarely occur. Many lakes exist between dunes and are an expression of the elevation of the water table. Some of the lakes in the western Sand Hills lie in closed basins that have no surface drainage from the lake. Lack of drainage and high evaporation rates cause these lakes to be highly saline (Gosselin and others, 1994b).

\section{Platte River Valley}

The PLAT unit includes alluvial sediments within the Platte River Valley of the northern High Plains. The PLAT unit consists of stream-deposited sand, gravel, and clay of Quaternary Pleistocene to Holocene age (5 million years ago to near present) (Waite and others, 1949). Although these sediments primarily originated from plains and mountains west of the study area, some sediments in the eastern part of the unit may be derived from glacial outwash. The thickness of these deposits is variable, ranging from a few feet to almost $200 \mathrm{ft}$ (Waite and others, 1949). At the base of this unit lie two types of geologic deposits-Cretaceous rocks underlie the eastern part of this unit, and the OGAL unit underlies the western part of the unit. Unsaturated sands and soil overlie this unit. In many areas, regional ground-water flow paths converge on the PLAT.

\section{Surficial Geology and Soils}

Surficial materials overlying the major hydrogeologic units vary across the northern High Plains. The main soil types are silt loam and sand; however, clay loam, loam, and sandy loam are present to a lesser extent. Either sand or loess is the parent material of most soils in the study area (Gutentag and others, 1984). The sandy soils that form from sand dunes have large infiltration rates, high permeability (fig. 5), and a reduced capacity to retain moisture relative to the other soils in the study area (Gutentag and others, 1984). As a result, these soils generally make poor cropland. The fine-grained loess deposits can be as thick as $200 \mathrm{ft}$ and restrict water flow where fractures are absent (Richmond and others, 1994; Johnson, 1960). Loess sediments are known for their ability to produce fertile soils. Average permeability and organic matter content of the soils in each hydrogeologic unit are listed in table 1.

\section{Land Use}

The economy in the northern High Plains is predominantly based on agriculture. In 1992, about 95 percent of the land in the northern High Plains was used either for cropland or rangeland/grazing (U.S. Geological Survey, 1992). Approximately 58 percent of the study area was rangeland and 37 percent of the northern High Plains was used for cropland. About 32 percent of cropland, or about 12 percent of the study area, was irrigated in 1980 (Thelin and Heimes, 1987). Less than 1 percent was characterized as urban land use. Forest, wetland, open water, and barren lands accounted for the remaining 5 percent of the study area (fig. 6). The dominant land uses overlying the aquifer vary by hydrogeologic unit (table 1). Rangeland is the primary land use overlying the SAND (83 percent) and cropland is the primary land use overlying the EAST ( 83 percent) and PLAT ( 65 percent) units. Land use in the OGAL is split between rangeland (52 percent) and cropland (46 percent) (table 2 ). The most common crops raised in the northern High Plains are corn, wheat, hay, soybeans, and sorghum.

The Platte River Valley was one of the first areas to be settled in the northern High Plains. Widespread agriculture in the northern High Plains also was first developed in this area, due, in part, to fertile soils, nearly flat land, and availability of surface and ground water for irrigation. Human population and irrigated cropland in the northern High Plains are most dense along the Platte River.

In the northern High Plains, agricultural chemicals, typically pesticides, fertilizers, and other amendments used to improve the physical properties of soils, are commonly applied to the land surface and have the potential to move 


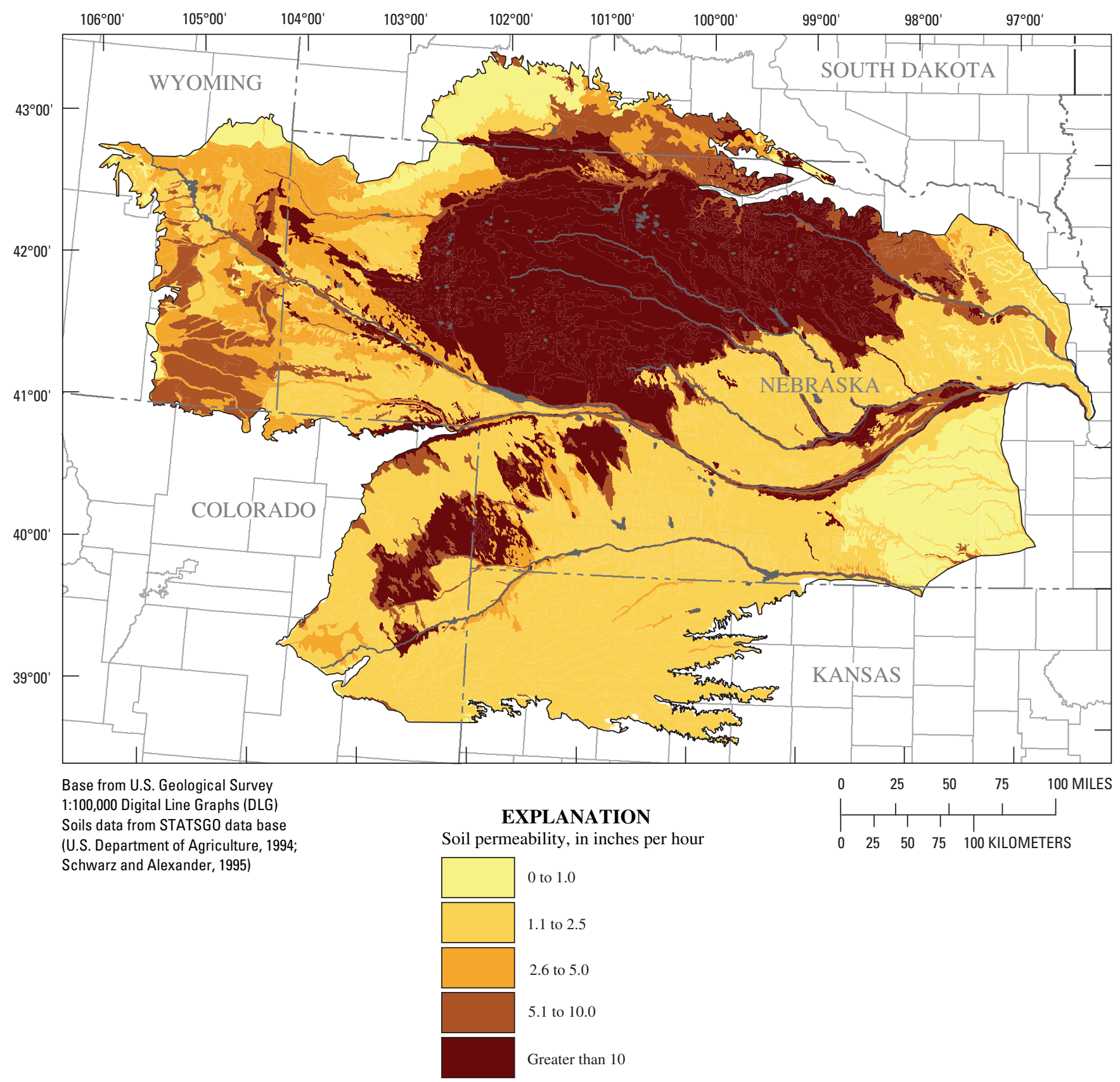

Figure 5. Permeability of soils overlying the northern High Plains aquifer.

past the soil horizon to ground water. Application of irrigation water in excess of crop needs further promotes transport of these agricultural chemicals to ground water. Nutrients, particularly nitrogen in the form of commercial fertilizers or manure, are applied to crops to increase yields. The application rates of total nitrogen, by hydrogeologic unit, are shown in table 3 (David Lorenz, U.S. Geological Survey, written commun., 1998). Percentage of cropland, percentage of irrigated cropland, and nitrogen application rates by county are shown in figure 7. Percent cropland, irrigated cropland, and nitrogen application rates are highest over the EAST and
PLAT units. Pesticides are primarily used in the study area to increase crop yields by controlling insects and competing vegetation. Pesticides also are used in smaller quantities around homes and livestock and along roads to control a wide variety of pests. The 10 most commonly applied pesticides in the northern High Plains are generally herbicides used on crops (table 3). Although the estimated application rates do not necessarily represent conditions during the time that water composing the ground-water samples was recharged, they do provide a general idea of the types and relative amounts of pesticides that are applied. 


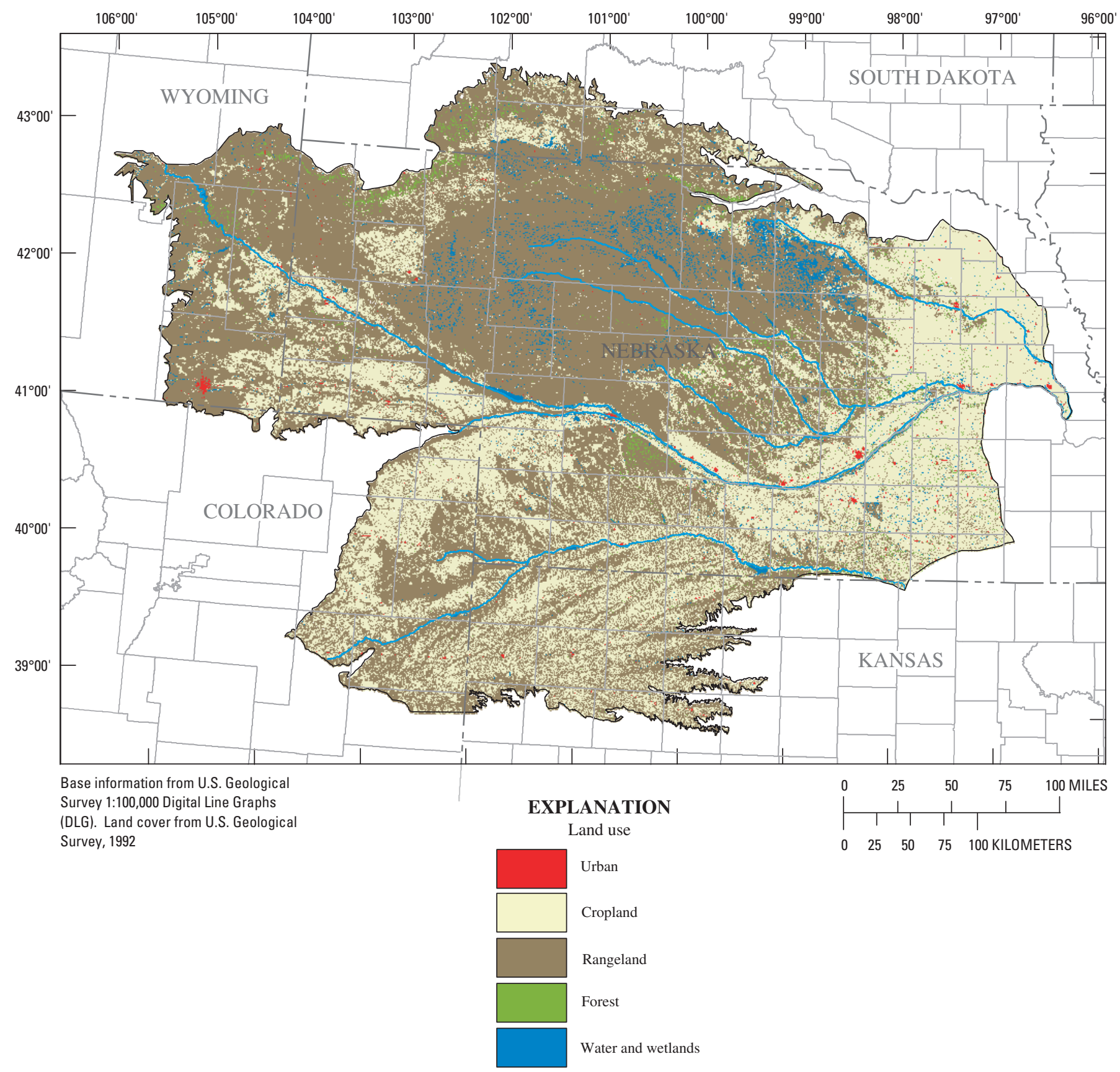

Figure 6. Land use in the northern High Plains, nominal 1992.

\section{Methods of Investigation}

\section{Well Selection}

Ground-water samples were collected from four of the five major hydrogeologic units in the northern High Plains between 1997 and 2004. Water samples were collected between 2002 and 2004 from three hydrogeologic units108 samples were collected from the OGAL unit during the spring and summer months of 2002-04, 30 samples were collected from the EAST unit in the spring and summer of 2003, and 27 samples were collected from the SAND unit in the summer of 2004. Financial constraints would not allow collection of water-quality samples from the BRAK or the PLAT units. However, 27 samples were collected from the PLAT in 1997 as part of an earlier NAWQA Program study. Waterquality results from those 27 samples are included in this report because they were collected and analyzed with similar methods, are part of an important ground-water resource that supplies water to a large part of the area's population, and provide additional information about the status of ground-water quality in an intensely cropped area. 
Table 2. Land use overlying four hydrogeologic units in the northern High Plains, 1992.

[Values are in percent; OGAL, Ogallala Formation; EAST, Eastern Nebraska; SAND, Sand Hills; PLAT, Platte River Valley; <, less than]

\begin{tabular}{lcccccc}
\hline $\begin{array}{c}\text { Hydrogeologic } \\
\text { unit }\end{array}$ & Cropland & Rangeland & Forest & Wetlands & Urban & Other \\
\hline OGAL & 46 & 52 & 1 & $<1$ & $<1$ & $<1$ \\
EAST & 83 & 12 & 2 & 1 & 1 & 1 \\
SAND & 10 & 83 & 1 & 6 & $<1$ & $<1$ \\
PLAT & 65 & 18 & 3 & 7 & 3 & 4 \\
\hline
\end{tabular}

Table 3. Estimated application rates of nitrogen and 10 most commonly applied pesticides.

[Nitrogen-use rates are from estimated county-level fertilizer (1998) and manure (1997) applications (David Lorenz, U.S. Geological Survey, written commun., 1998); pesticide-use rates compiled by the National Center for Food and Agricultural Policy (NCFAP) (1997) and applied to crop acreage from 1997 Census of Agriculture (U.S. Department of Agriculture, 1997); OGAL, Ogallala Formation; EAST, Eastern Nebraska; SAND, Sand Hills; PLAT, Platte River Valley]

\begin{tabular}{|c|c|c|c|c|c|}
\hline & OGAL & EAST & SAND & PLAT & $\begin{array}{c}\text { Northern } \\
\text { High Plains }\end{array}$ \\
\hline \multicolumn{6}{|c|}{ Total cropland nitrogen applications divided by total area of hydrogeologic unit, in pounds per acre } \\
\hline Nitrogen & 38 & 96 & 17 & 93 & 41 \\
\hline \multicolumn{6}{|c|}{$\begin{array}{l}\text { Total cropland pesticide applications divided by total area of hydrogeologic unit, } \\
\text { in pounds of active ingredient per acre }\end{array}$} \\
\hline Atrazine & 0.114 & 0.383 & 0.031 & 0.374 & 0.129 \\
\hline Metolachlor & 0.081 & 0.366 & 0.030 & 0.363 & 0.105 \\
\hline Glyphosate & 0.041 & 0.149 & 0.010 & 0.112 & 0.046 \\
\hline Acetochlor & 0.033 & 0.152 & 0.013 & 0.163 & 0.044 \\
\hline 2,4-D & 0.046 & 0.046 & 0.020 & 0.049 & 0.041 \\
\hline Alachlor & 0.013 & 0.070 & 0.005 & 0.043 & 0.017 \\
\hline Cyanazine & 0.012 & 0.051 & 0.004 & 0.054 & 0.015 \\
\hline Terbufos & 0.013 & 0.043 & 0.004 & 0.046 & 0.015 \\
\hline EPTC & 0.013 & 0.034 & 0.005 & 0.037 & 0.014 \\
\hline Dicamba & 0.014 & 0.023 & 0.006 & 0.025 & 0.014 \\
\hline
\end{tabular}

Only one type of well was sampled (except in the PLAT unit) to obtain comparable and consistent data within the study area as well as to facilitate comparisons to other similar NAWQA data across the Nation. Bruce and Oelsner (2001) identified significant water-quality differences between public-supply and domestic wells and concluded that well construction and pumping differences can affect the quality of the water in wells; therefore, domestic wells generally were selected for sampling for this study. Because the construction details of the targeted domestic wells were not required to be documented and registered with the State of Nebraska until fall of 1993, most of the domestic wells sampled in Nebraska, with the exception of the wells sampled from the PLAT unit, were less than 10 years old. Because the wells in the PLAT unit were selected for sampling in 1997, it was difficult to locate domestic wells that had documented construction information. Therefore, it was sometimes necessary to sample other types of small-capacity wells such as stock, monitoring, or observation wells. Stock, monitoring, and observation wells are considered to be small-capacity wells because they are generally pumped at a rate of $50 \mathrm{gal} / \mathrm{min}$ or less for short periods of time. Although it was not ideal to sample other well types, the effect of well type on ground-water-quality results should be minimal because pumping characteristics of these other small-capacity wells are generally similar to domestic wells.
Using domestic wells for evaluating ground-water quality in a national water-quality assessment is a good choice because of their geographic distribution and their construction and pumping characteristics. High-capacity wells, typically irrigation or public supply, are generally present in agricultural areas or clustered near municipalities, and domestic wells are more evenly distributed. High-capacity wells have longer screened intervals, higher pumping rates, and longer pumping periods. These characteristics are associated with a greater potential to mix younger water from multiple levels within the aquifer, which makes interpretations of the occurrence of anthropogenic contaminants problematic (Bruce and Oelsner, 2001). Gosselin and others (1994a) simulated the movement of ground-water contaminants to a high-capacity well and concluded that highcapacity wells do not accurately measure concentrations of contaminants in ground water. Domestic wells typically have shorter screened intervals that draw water from a discrete point in the aquifer. A random distribution of these short-screened domestic wells will produce a set of samples that draw water from a range of distinct depths across the aquifer. Sampling randomly selected domestic wells therefore provides a good indication of the variability of water quality with depth and an evaluation of the overall water-quality conditions within the aquifer. Domestic wells also were preferred to monitoring 

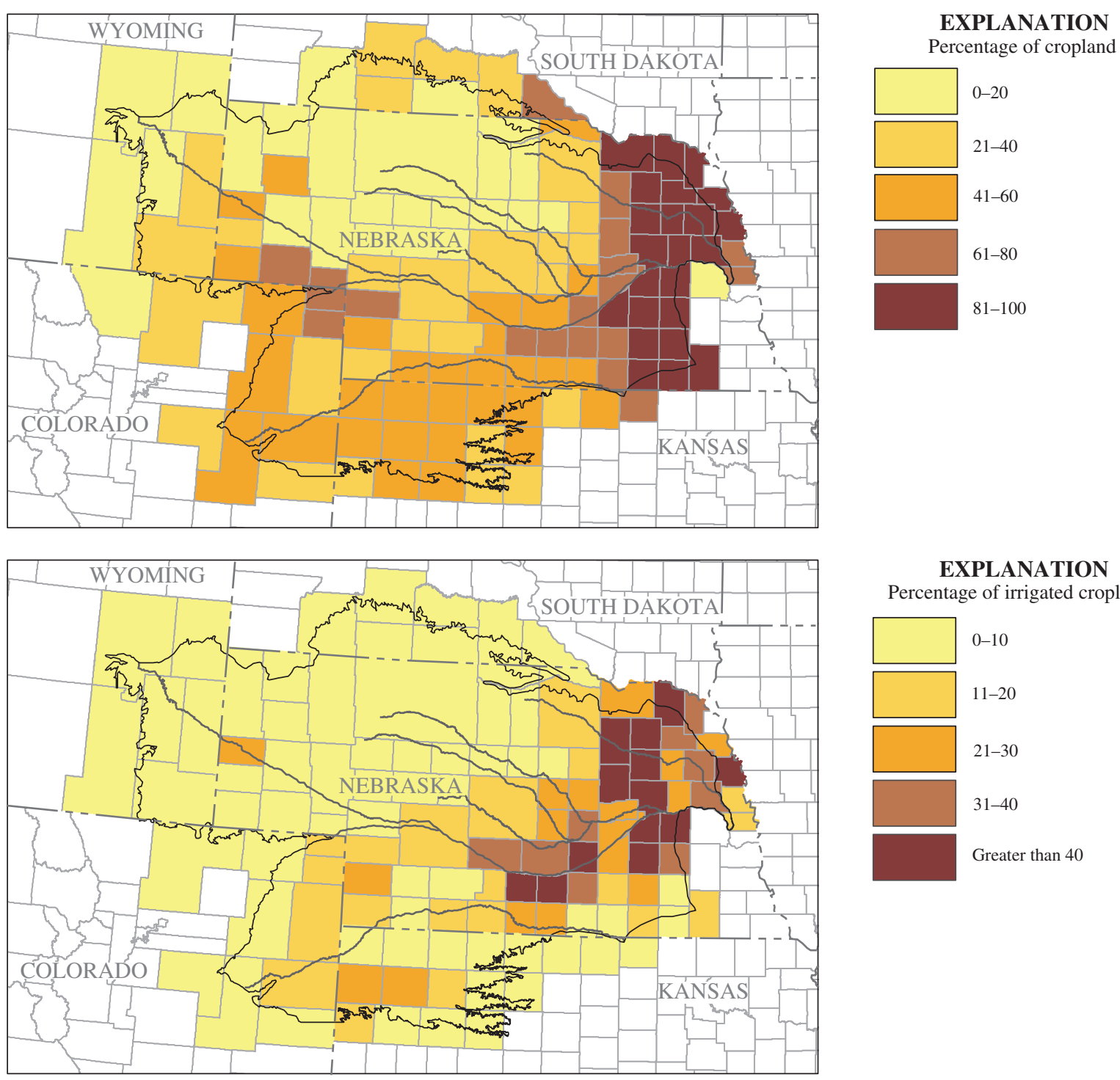

EXPLANATION

Percentage of irrigated cropland
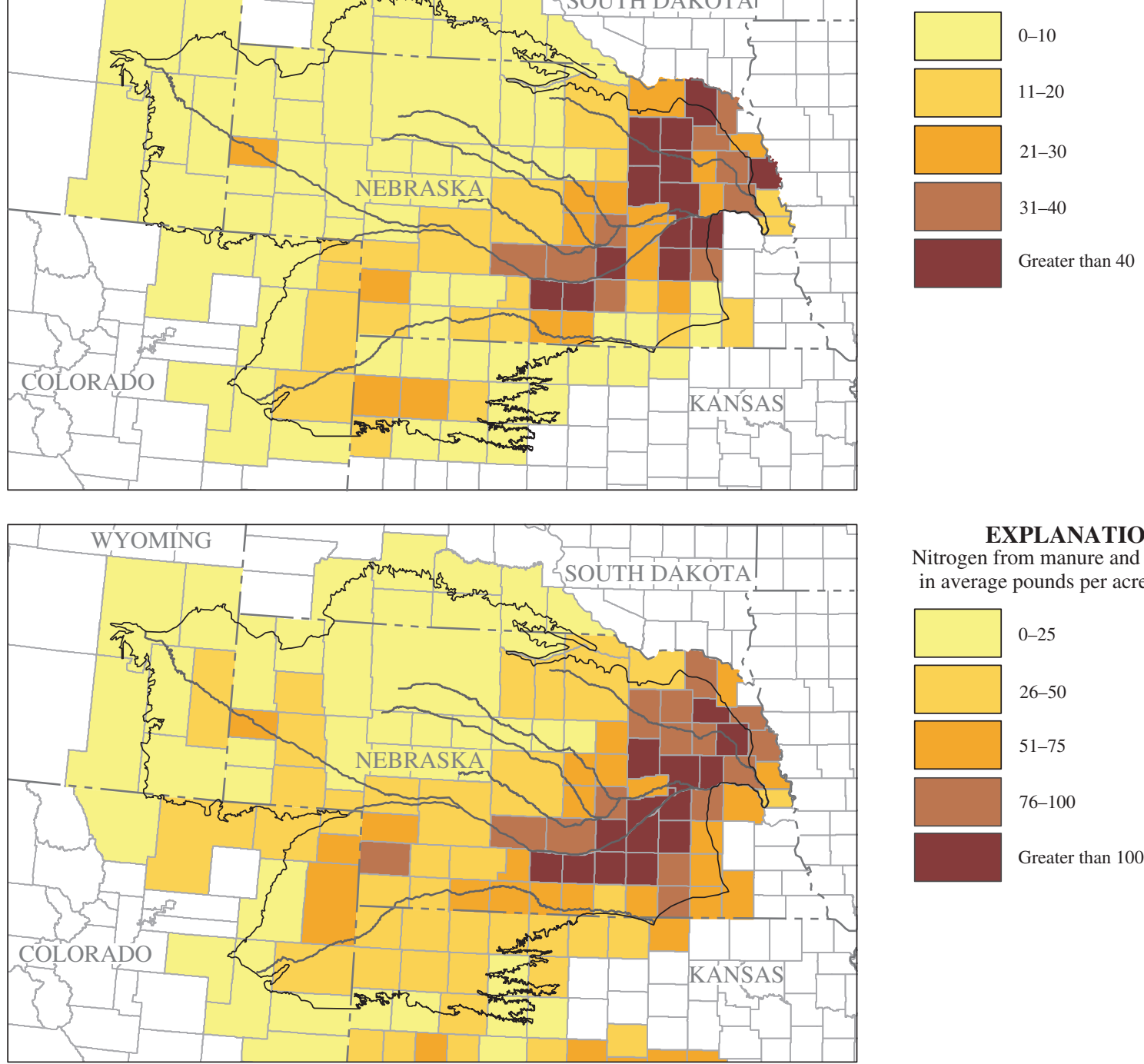

EXPLANATION

Nitrogen from manure and fertilizer, in average pounds per acre per year

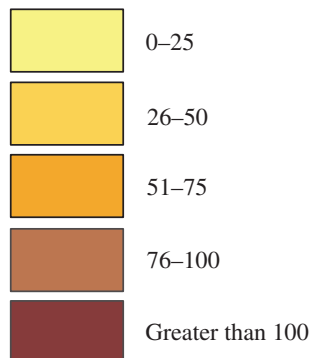

Figure 7. Percentage of cropland, percentage of irrigated cropland, and average pounds of nitrogen applied per acre of cropland in the northern High Plains. 
wells for purposes of this study because they already existed and were therefore a cost-effective alternative to drilling wells dedicated to monitoring water-quality conditions.

Investigating the water quality in domestic wells is an important step in protecting public health. Although a large number of people drink water that is supplied by privately owned domestic wells, the quality of this water is not examined as thoroughly as water from public-supply wells. The Safe Drinking Water Act (Public Law Title 42 USC 300j-6; 40 CFR 141-149) requires public-water suppliers to meet specific drinking-water standards. These standards are expressed as the highest safe concentration of a contaminant in drinking water. Regular testing is conducted by public-water suppliers to ensure that drinking-water standards are not exceeded. If needed, the water is treated to reduce contaminant concentrations to levels that are safe for human consumption, or well usage is discontinued. However, the Safe Drinking Water Act does not regulate private water-supply wells that serve fewer than 25 people (U.S. Environmental Protection Agency, 1999). Additional information on domestic well-water quality is of great value to landowners and public health agencies.

Potential ground-water sampling locations were selected using a grid-based random site-selection computer program (Scott, 1990). To utilize the program, the number of samples to collect from each unit was first determined. The goal was to obtain about one sample for every $500 \mathrm{mi}^{2}$ or, alternatively, a minimum of about 30 samples per hydrogeologic unit. The goal of 30 samples per hydrogeologic unit was set to achieve a sufficiently large number to satisfy the large-sample approximation for nonparametric statistical tests (Helsel and Hirsch, 1992). Once the number of sites was determined, a geographic information system (GIS) was used to divide the geographic extent of the unit into that number of equal-area cells. The computer program then randomly selected one primary and one alternate sampling location from a large population of potential sites within each cell. Because the OGAL extends to the central and southern High Plains, that unit was divided into equal-area cells over its entire extent in the High Plains to maintain a stratified-random distribution of sites across the entire hydrogeologic unit. However, only cells in the northern High Plains were considered for purposes of this report.

Existing wells near the randomly selected locations were evaluated to determine if they were suitable for sampling. A well was considered suitable to sample if (1) it was within a 4-mi radius of the randomly selected location; (2) it was a domestic well that was currently being used as a source of household drinking water (in the PLAT, other small-capacity wells also were selected); (3) it could be documented from construction information that the well withdrew water from the appropriate hydrogeologic unit; (4) it was possible to collect a water sample prior to any water treatment or storage tank; (5) it had a dedicated submersible pump, or a portable submersible pump could be used to collect water; and (6) the well owner granted permission to sample. If no wells within the 4-mi radius were suitable to sample, wells near the alternate randomly selected location were considered, using the listed criteria. If no wells within the alternate 4-mi radius were suitable to sample, the search radius was extended to $10 \mathrm{mi}$, first at the primary location, then at the alternate location. If no wells were suitable to sample in either the primary or alternate 10-mi radius, the site was dropped from the sampling network. As a result, some cells are not represented by a ground-waterquality sample: in the OGAL (northern High Plains only) unit, 133 equal-area cells were created and 108 wells were sampled. The cells that were not sampled were mostly in areas where the OGAL was overlain by another important ground-water source (for example, the SAND) and few domestic wells were drilled deep enough to penetrate the OGAL unit. In the SAND unit, 45 cells were created and 27 wells were sampled, in the EAST unit 30 cells were created and 30 wells were sampled, and in the PLAT unit 30 cells were created and 27 wells were sampled. Construction information for the sampled wells is summarized in Appendix 1.

\section{Sample Collection and Analysis}

Ground-water samples were collected from domestic wells using procedures described by Koterba and others (1995) and the USGS National Field Manual (U.S. Geological Survey, variously dated). Water samples were analyzed for about 200 constituents at the USGS National Water Quality Laboratory (NWQL) in Lakewood, Colorado. Concentrations of nitrogen and phosphorus compounds, pesticides and pesticide degradates, dissolved solids, major ions, trace elements, DOC, radon, and VOCs were determined in each sample (table 4). Water samples from selected sites were chosen for tritium age dating to determine a relative estimate of when water recharged the aquifer. In general, samples without other indicators of modern human effects (no pesticides or VOCs detected and nitrate less than $4 \mathrm{mg} / \mathrm{L}$ ) were submitted for tritium age-dating analysis. Tritium analysis was completed by the USGS Isotope Tracers Laboratory in Menlo Park, California. Bacteria and viral biological indicators were analyzed in water only from the SAND and the EAST units. Total coliforms and Escherichia coli (E. coli) samples were incubated onsite and resulting bacterial colonies were counted the day after sample collection. Viral coliphage analysis was completed by the USGS Microbiology Laboratory in Columbus, Ohio. Measurements of specific conductance, $\mathrm{pH}$, water temperature, turbidity, dissolved oxygen, carbonate alkalinity, and depth to ground water were completed onsite. Hydrogen sulfide was measured onsite if the dissolved-oxygen concentration was less than $1 \mathrm{mg} / \mathrm{L}$.

Water samples were processed and preserved onsite in a mobile laboratory by using methods designed to minimize alteration of the water-sample chemistry. Water from wells was delivered to the mobile laboratory through Teflon tubing with stainless-steel connections. The tubing was attached to an existing domestic well spigot prior to any water-treatment devices or holding tanks. Plumbing connections were sometimes temporarily modified if a spigot prior to treatment or holding was not available. If water could not be accessed prior to treatment or holding tank, the well was not sampled. 
Table 4. Laboratory analysis and field preservation methods for measured water-quality constituents in the northern High Plains, 1997, 2002-04.

[ $\mu \mathrm{m}$, micrometer; USGS, U.S. Geological Survey; NWQL, National Water Quality Laboratory; C, Celsius; GC/MS, gas chromatography/mass spectrometry; HPLC, high-performance liquid chromatography; mm, millimeter; UV, ultraviolet; <, less than; mL, milliliter; E. coli, Escherichia coli]

\begin{tabular}{|c|c|c|c|c|}
\hline $\begin{array}{c}\text { Constituent or } \\
\text { constituent group }\end{array}$ & $\begin{array}{l}\text { Analyzing } \\
\text { laboratory }\end{array}$ & Analytical method(s) & Reference(s) & $\begin{array}{c}\text { Field preservation } \\
\text { procedure(s) }\end{array}$ \\
\hline $\begin{array}{l}\text { Carbonate } \\
\text { alkalinity }\end{array}$ & Analyzed onsite & Inflection point titration & Koterba and others, 1995 & Filter through $0.45-\mu \mathrm{m}$ filter. \\
\hline $\begin{array}{l}\text { Pesticides and } \\
\text { pesticide } \\
\text { degradates }\end{array}$ & USGS NWQL & $\begin{array}{l}\text { C-18 solid-phase extraction } \\
\text { and capillary-column } \\
\text { GC/MS; graphitized } \\
\text { carbon-based solid-phase } \\
\text { extraction and HPLC/mass } \\
\text { spectrometry }\end{array}$ & $\begin{array}{l}\text { Zaugg and others, 1995; Lindley } \\
\text { and others, 1996; Madsen and } \\
\text { others, 2003; Furlong and } \\
\text { others, 2001; Werner and others, } \\
1996\end{array}$ & $\begin{array}{l}\text { Filter through } 142-\mathrm{mm} \text { baked } \\
\text { glass fiber filter, chill sample } \\
\text { and maintain at } 4^{\circ} \mathrm{C} \text {. }\end{array}$ \\
\hline $\begin{array}{l}\text { Trace } \\
\text { elements }\end{array}$ & USGS NWQL & $\begin{array}{l}\text { Inductively coupled plasma, } \\
\text { atomic absorption } \\
\text { spectrometry }\end{array}$ & $\begin{array}{l}\text { Faires, 1993; Fishman and } \\
\text { Friedman, 1989; Garbarino, } \\
\text { 1999; McLain, } 1993\end{array}$ & $\begin{array}{l}\text { Filter through } 0.45-\mu \mathrm{m} \text { filter, } \\
\text { acidify sample to } \mathrm{pH}<2 \text { with } \\
\text { nitric acid }\left(\mathrm{HNO}_{3}\right) .\end{array}$ \\
\hline $\begin{array}{l}\text { Dissolved } \\
\text { organic } \\
\text { carbon }\end{array}$ & USGS NWQL & $\begin{array}{l}\text { UV-light promoted persulfate } \\
\text { oxidation and infrared } \\
\text { spectrometry }\end{array}$ & Brenton and Arnett, 1993 & $\begin{array}{l}\text { Filter through } 25-\mathrm{mm} \text { baked } \\
\text { glass fiber filter, acidify to } \\
\mathrm{pH}<2 \text { with } 1 \mathrm{~mL} \text { of } 4.5 \mathrm{~N} \\
\text { sulfuric acid }\left(\mathrm{H}_{2} \mathrm{SO}_{4}\right) \text {, chill } \\
\text { and maintain at } 4^{\circ} \mathrm{C} \text {. }\end{array}$ \\
\hline Radon & USGS NWQL & Liquid scintillation & $\begin{array}{l}\text { American Society for Testing } \\
\text { and Materials, } 1996\end{array}$ & $\begin{array}{l}\text { 20-mL glass vial filled with } \\
10 \mathrm{~mL} \text { mineral oil liquid } \\
\text { scintillation cocktail and } \\
10 \mathrm{~mL} \text { of sample. Sample } \\
\text { must be received at } \\
\text { laboratory within } 48 \text { hours } \\
\text { of collection. }\end{array}$ \\
\hline Tritium & $\begin{array}{l}\text { USGS Isotope } \\
\text { Tracers } \\
\text { Laboratory }\end{array}$ & $\begin{array}{l}\text { Electrolytic enrichment } \\
\text { and liquid scintillation }\end{array}$ & Thatcher and others, 1977 & $\begin{array}{l}\text { Completely fill bottle to } \\
\text { exclude air bubbles, } \\
\text { fill bottle with minimal } \\
\text { splashing. }\end{array}$ \\
\hline $\begin{array}{l}\text { Total coliforms } \\
\text { and } E \text {. coli }\end{array}$ & Analyzed onsite & $\begin{array}{l}\text { Membrane filtration } \\
\text { (MI medium) }\end{array}$ & $\begin{array}{l}\text { U.S. Environmental Protection } \\
\text { Agency, } 2002 \text { (Method 1604) }\end{array}$ & None. \\
\hline $\begin{array}{l}\text { Somatic and } \\
\text { F-specific } \\
\text { coliphage }\end{array}$ & $\begin{array}{l}\text { USGS Microbiology } \\
\text { Laboratory }\end{array}$ & Two-step enrichment & $\begin{array}{l}\text { U.S. Environmental Protection } \\
\text { Agency, } 2000 \text { (Method 1601) }\end{array}$ & $\begin{array}{l}\text { Chill and maintain at } 4^{\circ} \mathrm{C} \text {. } \\
\text { Sample must be received at } \\
\text { laboratory within } 48 \text { hours of } \\
\text { collection. }\end{array}$ \\
\hline
\end{tabular}


Prior to sample collection, at least three casing volumes were purged to flush any stagnant water from the well. As the well was purged, water temperature, specific conductance, $\mathrm{pH}$, dissolved oxygen, and turbidity were measured until readings were stable (U.S. Geological Survey, variously dated). Once readings had stabilized, water samples were collected in precleaned bottles within an enclosed chamber to prevent sample contamination by airborne particles.

To prevent degradation of water samples and maintain the initial concentration of compounds between the time of sample collection and laboratory analyses, bottles were preserved according to the requirements of the laboratories. Preservation practices differ among analytes and may include chilling, filtration, and(or) chemical treatment (table 4).

\section{Data Treatment}

In 1998, the NWQL began implementing a new method for reporting analytical results (Childress and others, 1999). Two concentration levels are used in the new method, the long-term method detection level (LT-MDL) and the laboratory reporting level (LRL), to minimize both false positive and false negative errors. LT-MDLs and LRLs vary among constituents and analytical methods. The LT-MDL is determined from the standard deviation of long-term laboratory spike-sample measurements and is set to the level at which false positive errors are minimized to no more than 1-percent probability. The LRL is set to the level at which false negative errors are minimized to no more than 1-percent probability and is generally equal to twice the LT-MDL. Using this reporting convention, if a reported concentration is greater than both the LRL and the smallest laboratory calibration standard, it is not censored or qualified. If a reported concentration is smaller than the LT-MDL, it is coded as "less than" the LRL, unless information-rich laboratory methods (organic constituent methods that have additional qualitative information provided by the instrumentation) are used. LT-MDLs and LRLs are annually reevaluated by the NWQL based on laboratory spike-sample measurements and may change with time. Concentrations are qualified as estimated in several situations. If a reported concentration is smaller than either the LRL or the smallest laboratory calibration standard but greater than the LT-MDL, the value is qualified as estimated using an "E" remark code. An " $E$ " remark code also is used if the reported concentration is larger than the largest laboratory calibration standard. Pesticide and volatile organic compounds were analyzed and reported using information-rich laboratory methods. These methods report concentrations smaller than the LT-MDL if an analyte is positively identified and all other laboratory quality-control criteria are satisfied. The reported concentrations smaller than the LT-MDL are qualified with an "E" remark code. Finally, if a compound does not meet method-specific performance criteria, it is qualified with an " $E$ " remark code.

Water-quality data characteristically include data "outliers" (observations much larger or smaller than most of the data), censored data, and positive skewness (most data are at low values, but a few extreme high values are present). For these reasons, nonparametric statistical methods were used in this report. The nonparametric Wilcoxon, or Mann-Whitney, rank-sum test (two-sided) was used to compare observations between groups of data (Wilcoxon, 1945). In this report, a p-value of 0.10 or lower indicated sufficient confidence that there was a significant difference between two groups of data. If more than 50 percent of the values were censored, no statistical comparison was attempted. The nonparametric Spearman's rho test was used to correlate observations between variables (Bhattacharyya and Johnson, 1977). In this report, a p-value of 0.10 or lower indicated sufficient confidence that two groups of data were correlated.

To apply statistical tests, it was sometimes necessary to substitute censored ("less than") values with a numeric value. Substitutions were applied using methods described by Helsel (2005) and were dependent upon the laboratory reporting methods of each constituent. Data were reported for most constituents using the old (pre-1998) and the new NWQL methods. For these constituents, censored and estimated data values less than the highest reporting level were set to a value smaller than the highest reporting level to effectively be treated as a tied rank. For constituents having data reported using only the new NWQL methods, censored data were set to a value smaller than the smallest LT-MDL and estimated values were treated as quantitative results. For purposes of this report, a concentration was only identified as a detection if the value was at or above the highest reporting level reported for that analyte.

\section{Quality Assurance}

Additional samples were collected to assess the reliability of sample processing and analytical methods. These qualitycontrol samples included field- and source-solution blank samples, replicate samples, and matrix-spike samples. Qualitycontrol samples approach about 30 percent of the total samples analyzed.

\section{Field-Blank and Source-Solution Blank Samples}

Field-blank samples were collected to determine the occurrence and magnitude of sample contamination during sample collection, processing, transport, and analysis. Blank samples were collected using water that was specially prepared at NWQL and certified to be free of the environmental sample analytes. Blank samples were otherwise processed using the same procedures and equipment as the environmental samples. Blank samples were analyzed for nitrogen and phosphorus compounds, pesticide compounds, major ions, trace elements, DOC, and VOCs. It is not possible to prepare meaningful dissolved gas or isotope blank samples; therefore, radon and tritium blank samples were not collected. In addition to the field-blank sample, a filter-blank sample was processed prior to collecting total coliforms and E. coli 
samples to verify that the equipment and supplies were sterile. Filter-blank sample results indicated that equipment and supplies did not contaminate bacteria samples.

Field-blank sample results are summarized in table 5. Concentrations of analytes detected in blank samples were compared with concentrations of analytes in environmental samples to determine the potential for environmental sample contamination. If the magnitude of the blank sample concentration was in close range to the environmental sample concentration, environmental sample concentrations may have been affected by background contamination. Concentrations in blank samples indicated that sample contamination was minimal with the exception of DOC in the PLAT unit and a few trace elements and VOCs. These constituents were detected in blank samples at concentrations at or above environmental sample concentrations, indicating that environmental sample data for these constituents should be used with caution. DOC was detected in 6 of the 22 blank samples collected from the northern High Plains and in all three of the blank samples collected from the PLAT unit. The median concentration of detected DOC in the three samples from the PLAT unit was $1.8 \mathrm{mg} / \mathrm{L}$, and the median concentration of detected DOC in the three samples from the remaining units was $0.3 \mathrm{mg} / \mathrm{L}$. Therefore, DOC values from the PLAT unit were not considered in this report. Concentrations of aluminum, copper, 1,2,4-trimethylbenzene, and tetrahydrofuran were detected in field-blank samples at similar concentrations to environmental samples; therefore, reported concentrations of these constituents may be unreliable. In addition, contamination during sample collection and processing was suspected for several VOCs (1,2,4-trimethylbenzene, chloromethane, meta- + para- xylene, and toluene) in PLAT samples, and therefore reported values of those VOCs in PLAT samples are not used in this report. Other constituents were detected in blank samples but at such a low frequency and concentration that reported environmental sample concentrations can be considered reliable.

An extra quality-assurance step was conducted to determine whether the prepared blank water was a potential source of contamination in VOC samples. A source-solution blank was collected every time a VOC blank sample was collected but generally analyzed only if detections of VOCs were detected in the blank sample. This additional blank sample was collected by pouring the prepared blank water directly into the sample bottles, circumventing the field equipment that blank water is normally passed through. The VOCs detected in blank samples were not detected in source-solution blanks, indicating that the prepared water was not the source of contamination. Styrene was detected in one source-solution blank but not in field-blank or environmental samples.

Table 5. Constituents detected in field-blank samples collected in the northern High Plains 1997, $2002-04$.

[mg/L, milligrams per liter; <, less than; --, no data; $\mu \mathrm{g} / \mathrm{L}$, micrograms per liter; E, estimated]

\begin{tabular}{|c|c|c|c|c|}
\hline Constituent & $\begin{array}{c}\text { Number of } \\
\text { detections } 1 / \text { number of } \\
\text { field-blank samples }\end{array}$ & $\begin{array}{c}\text { Median concentration } \\
\text { of detected analytes } \\
\text { in field-blank samples }\end{array}$ & $\begin{array}{c}\text { Maximum } \\
\text { concentration } \\
\text { in field-blank } \\
\text { samples } \\
\end{array}$ & $\begin{array}{c}\text { Range of } \\
\text { concentrations } \\
\text { in environmental } \\
\text { samples } \\
\end{array}$ \\
\hline \multicolumn{5}{|c|}{ Nitrogen and phosphorus compounds (concentrations in mg/L) } \\
\hline Nitrate & $2 / 17$ & 0.07 & 0.08 & $<0.05-48.0$ \\
\hline Ammonia & $1 / 17$ & -- & 0.06 & $<0.01-1.02$ \\
\hline Nitrite & $1 / 17$ & -- & 0.029 & $<0.008-0.172$ \\
\hline \multicolumn{5}{|c|}{ Pesticides } \\
\hline \multicolumn{5}{|l|}{ None detected } \\
\hline \multicolumn{5}{|c|}{ Major ions (concentrations in mg/L) } \\
\hline Calcium & $15 / 17$ & 0.02 & 0.51 & $7.75-298$ \\
\hline Silica & $8 / 17$ & 0.3 & 0.97 & $10.2-74.8$ \\
\hline Magnesium & $1 / 17$ & -- & 0.212 & $1.40-65.2$ \\
\hline Sodium & $1 / 17$ & -- & 0.43 & $3.05-396$ \\
\hline \multicolumn{5}{|c|}{ Trace elements (concentrations in $\mu \mathrm{g} / \mathrm{L}$ ) } \\
\hline Aluminum & $8 / 24$ & 5 & 10 & $<1-52$ \\
\hline Copper & $4 / 24$ & 2.8 & 3.8 & $<0.2-16.5$ \\
\hline Zinc & $3 / 24$ & 4.8 & 8.3 & $<0.6-129$ \\
\hline Iron & $1 / 17$ & -- & 25 & $<3-2,710$ \\
\hline \multicolumn{5}{|c|}{ Dissolved organic carbon (concentrations in mg/L) } \\
\hline Dissolved organic carbon & $6 / 22$ & 1.0 & 6.8 & $<0.3-25.5$ \\
\hline \multicolumn{5}{|c|}{ Volatile organic compounds (concentrations in $\mu \mathrm{g} / \mathrm{L}$ ) } \\
\hline 1,2,4-trimethylbenzene & $2 / 23$ & 0.6 & 1.13 & $<0.06-\mathrm{E} 0.09$ \\
\hline Toluene & $2 / 23$ & 0.09 & 0.12 & None detected $^{1}$ \\
\hline Tetrahydrofuran & $1 / 23$ & -- & E3 & $<1-\mathrm{E} 4$ \\
\hline meta- plus para- Xylene & $1 / 23$ & -- & E0.06 & None detected ${ }^{1}$ \\
\hline Benzene & $1 / 23$ & -- & $\mathrm{E} 0.04$ & None detected $^{1}$ \\
\hline
\end{tabular}

\footnotetext{
${ }^{1}$ At or above the highest laboratory reporting level (LRL).
} 


\section{Replicate Samples}

Replicate samples are two environmental samples collected sequentially to represent a duplication of the same sample water. They are collected to determine variability of the data as a result of sampling and analytical procedures. The relative percent difference (RPD) between concentrations of paired replicate samples was calculated using the formula:

$$
R P D=\frac{\mid \text { sample } 1-\text { sample } 2 \mid}{\left(\frac{\text { sample } 1+\text { sample } 2}{2}\right)} \times 100
$$

When there is no variability between the paired analyses, the RPD will be zero percent. RPD calculations are summarized in table 6 . The RPD was not calculated if one or both of the paired replicate concentrations were below a laboratory reporting level (LRL) or identified as an estimated value by the laboratory. The median RPD of constituent groups ranged from 0.0 to 4.3 percent. Constituent groups having larger median RPDs generally had many constituents with concentrations near the LRL. At such low concentrations, small differences can cause large calculated variability. The individual constituents having the largest average RPDs were aluminum (29 percent), ammonia plus organic nitrogen (22 percent), thallium (15 percent), and iron (10 percent). In general, RPDs for constituents indicated that the amount of variability between paired environmental and replicate samples was within acceptable limits.

\section{Matrix-Spike Samples}

Environmental field-matrix spikes typically are used for organic compounds. They are collected to quantify the gain or loss of analytes due to water-matrix properties, sample holding time, or field and laboratory procedures. A spike recovery of 100 percent indicates no matrix interference or degradation. Environmental field-matrix spike samples were prepared by injecting exact amounts of target analytes into replicate sample bottles while onsite.

A pesticide field matrix-spike sample was prepared at 14 sites. The prepared spike solution contained 110 pesticide compounds. Table 6 summarizes the percent recoveries of the spiked pesticide samples. The median percent recovery of all pesticide compounds in the 14 spiked samples was about 90 percent. The mean percent recovery of each pesticide compound was calculated from the 14 matrix-spike samples and is reported in Appendix 2. Ninety of the 110 pesticide compound matrix spikes analyzed were within an acceptable range (60 to 120 percent, Furlong and others, 2001). Of the remaining 20 pesticide compounds analyzed that did not fall into the range of acceptable recovery, 15 are always reported as estimated values by the NWQL because of known problems with gas chromatography or extraction or do not otherwise meet method performance criteria (Zaugg and others, 1995; Furlong and others, 2001; James Lewis, U.S. Geological Survey, written commun., 2003). Two pesticides (bentazon and deethylatrazine) detected in environmental samples collected from the northern High Plains aquifer had average

Table 6. Summary of relative percent differences for replicate samples and percent recoveries for field matrix-spike samples collected in the northern High Plains, 1997, 2002-04.

$[--$, not calculated, few replicated values]

\begin{tabular}{|c|c|c|c|c|c|c|c|c|}
\hline \multirow[b]{2}{*}{ Compound class } & \multirow{2}{*}{$\begin{array}{c}\text { Number of } \\
\text { replicated } \\
\text { values }^{1}\end{array}$} & \multirow[b]{2}{*}{ Minimum } & \multicolumn{5}{|c|}{ Percentile } & \multirow[b]{2}{*}{ Maximum } \\
\hline & & & 10 & 25 & 50 & 75 & 90 & \\
\hline \multicolumn{9}{|c|}{ Environmental sample replication (relative percent difference, in percent) $^{1}$} \\
\hline Pesticide and pesticide degradates (106 compounds) & 2 & 0.0 & -- & -- & -- & -- & -- & 5.5 \\
\hline Dissolved solids & 14 & 0.0 & 0.3 & 0.5 & 0.8 & 1.9 & 4.3 & 9.7 \\
\hline Major ions (10 constituents) & 143 & 0.0 & 0.0 & 0.0 & 0.6 & 1.3 & 2.9 & 28.6 \\
\hline Radon & 15 & 0.0 & 0.0 & 2.6 & 4.3 & 12.1 & 17.4 & 20.7 \\
\hline Volatile organic compounds ( 85 compounds) & 0 & -- & -- & -- & -- & -- & -- & -- \\
\hline Tritium & 4 & 0.0 & 0.0 & 0.0 & 1.4 & 3.0 & 3.5 & 3.9 \\
\hline Indicator bacteria & 114 & 0.0 & 0.0 & 0.0 & 0.0 & 0.0 & 0.0 & 200 \\
\hline Viral coliphage & 2 & 0.0 & -- & -- & -- & -- & -- & 0.0 \\
\hline \multicolumn{9}{|c|}{ Field matrix-spike replication (relative percent difference, in percent) } \\
\hline Volatile organic compounds (14 compounds) $)^{2}$ & 28 & 0.0 & 60.7 & 81.5 & 91.9 & 94.6 & 98.9 & 103.8 \\
\hline \multicolumn{9}{|c|}{ Laboratory matrix-spike recoveries (in percent) } \\
\hline Volatile organic compounds (85 compounds) & 340 & 42.1 & 82.9 & 89.3 & 100.0 & 110.6 & 118.0 & 148.9 \\
\hline
\end{tabular}


matrix-spike recoveries of less than 60 percent. These compounds are always reported as estimated by the NWQL, and environmental sample results should be used with caution. In addition to environmental field-matrix spikes, two replicate matrix-spike samples were collected from the PLAT unit. The RPDs between paired replicate matrix spikes is summarized in table 6.

A VOC matrix-spike sample was prepared at six sites. Two of the VOC matrix-spike samples were field-prepared spikes; spike solution containing 14 VOCs was added to sample bottles onsite. Four of the VOC matrix-spike samples were laboratory-prepared spikes; spike solution containing 85 VOCs was added to sample bottles at the NWQL. Table 6 summarizes percent recoveries of field and laboratory matrixspike samples. The median percent recovery of the fieldprepared spikes was about 92 percent, and the median percent recovery of the laboratory-prepared spikes was about 100 percent. The mean percent recovery for each VOC compound was calculated for the two field-prepared spikes and the four laboratory-prepared spikes separately (Appendix 3). The mean percent recovery of field-prepared matrix spikes ranged from 0.0 to 103.8 percent. The mean percent recovery of laboratoryprepared matrix spikes ranged from 74.6 to 118.0 percent, indicating that environmental results are probably not affected by matrix interference, method performance, or sample degradation.

\section{Ground-Water Quality}

Ground water from 192 wells was analyzed or measured for physical properties, field measurements of carbonate alkalinity, hydrogen sulfide, and ground-water level, and concentrations of nitrogen and phosphorus compounds, pesticides and pesticide degradates, dissolved solids, major ions, trace elements, DOC, radon, and VOCs. Bacteria, viral coliphage, and tritium concentrations were analyzed at selected sites. Results are provided as part of this report on CD-ROM, in Microsoft Access and tab-delimited ASCII formats. Concentrations of constituents were compared with U.S. Environmental Protection Agency (USEPA) drinkingwater standards (U.S. Environmental Protection Agency, 2004) in order to place the quality of rural domestic drinking water in the context of nationally recognized public-supply criteria. The USEPA has established several kinds of drinkingwater standards. The maximum contaminant level (MCL) is the highest level of a contaminant that is allowed in publicly supplied drinking water. The secondary drinking-water regulation (SDWR) is a nonenforceable guideline regarding cosmetic or esthetic effects of drinking water. The maximum contaminant level goal (MCLG) as defined by the USEPA is "a nonenforceable health goal set at a level at which no known or anticipated adverse effect on the health of persons occurs and which allows an adequate margin of safety." The treatment technique (TT) specifies a constituent concentration above which a public water supplier is required to physically remove the constituent from delivered water. The USEPA defines the Lifetime Health Advisory (LTHA) as the "concentration of a chemical in drinking water that is not expected to cause any adverse noncarcinogenic effects for a lifetime of exposure." Relations between concentrations of water-quality constituents and hydrogeologic and land-use factors were evaluated statistically.

\section{Physical Properties and Field Measurements}

Turbidity, dissolved oxygen, $\mathrm{pH}$, water temperature, specific conductance, and carbonate alkalinity were measured onsite at every well. These properties are measured onsite because accurate field equipment is available to measure them and they are generally unstable and would likely change during sample transport to the laboratory. Carbonate alkalinity concentrations are discussed in the "Dissolved Solids, Major Ions, and Trace Elements" section. Hydrogen sulfide was measured onsite when the dissolved-oxygen concentration was less than $1 \mathrm{mg} / \mathrm{L}$. Depth to water was measured at 184 sites (Appendix 1). This measurement was not possible at eight wells due to obstructions in those wells; therefore, a previously measured water level is reported.

\section{Turbidity}

Turbidity is a measurement of the concentration of suspended sediment in water. Turbidity was generally low in the northern High Plains aquifer. The median turbidity was 0.1 nephelometric turbidity unit (NTU) (table 7). Turbidity was significantly larger in the EAST unit than in either the OGAL ( $p=0.030)$ or the SAND $(p=0.041)$ units. Turbidity was not measured in the PLAT unit. One sample in the EAST unit (NQS-113) exceeded the USEPA TT of 5 NTU.

\section{Dissolved Oxygen and Redox Conditions}

The concentration of dissolved oxygen in ground water can help predict microbially mediated reduction-oxidation (redox) reactions in the aquifer. These reactions play a prominent role in many ground-water contamination investigations and can affect the concentrations of nitrogen compounds, some major ions and trace elements, and organic compounds such as DOC, pesticides, and VOCs. Oxygen concentrations in water can be reduced when the oxygen acts as an electron receptor in redox reactions with material such as organic matter (animal waste, decomposed plant material, pesticides, or VOCs) or reduced inorganic minerals along the flow path. If organic matter and dissolved oxygen are present in ground water, microorganisms can facilitate reactions of oxygen with decomposing organic matter to produce carbon dioxide and water. In this process, organic compounds are oxidized, releasing electrons that oxygen atoms accept to become reduced. 
Table 7. Median values for physical properties, water levels, and depths of well screen in the northern High Plains aquifer, 1997, 2002-04.

[OGAL, Ogallala Formation; EAST, Eastern Nebraska; SAND, Sand Hills; PLAT, Platte River Valley; mg/L, milligrams per liter; --, no standard has been determined; SDWR, Secondary Drinking-Water Regulations; $\mu \mathrm{S} / \mathrm{cm}$, microsiemens per centimeter; ${ }^{\circ} \mathrm{C}$, degrees Celsius; NTU, nephelometric turbidity unit; NA, not measured; TT, Treatment Technique]

\begin{tabular}{|c|c|c|c|c|c|c|}
\hline Constituent or property & OGAL & EAST & SAND & PLAT & $\begin{array}{l}\text { Northern } \\
\text { High Plains }\end{array}$ & $\begin{array}{l}\text { USEPA drinking- } \\
\text { water standard / } \\
\text { type of standard' }\end{array}$ \\
\hline Turbidity, in NTU & 0.1 & 0.2 & 0.1 & NA & 0.1 & $5 / \mathrm{TT}$ \\
\hline $\mathrm{pH}$, in standard units & 7.6 & 7.2 & 7.4 & 7.2 & 7.5 & 6.5-8.5 / SDWR \\
\hline Temperature, in ${ }^{\circ} \mathrm{C}$ & 14.2 & 12.7 & 12.1 & 12.5 & 13.4 & -- \\
\hline Specific conductance, in $\mu \mathrm{S} / \mathrm{cm}$ at $25^{\circ} \mathrm{C}$ & 399 & 620 & 181 & 721 & 429 & -- \\
\hline
\end{tabular}

${ }^{1}$ Source: U.S. Environmental Protection Agency, 2004.

If oxygen is depleted, bacteria can use nitrate, if available, as the electron acceptor, eventually converting nitrate to inert nitrogen gas through a series of reactions. This process, called denitrification, can naturally decrease nitrate concentrations in aquifers. If oxygen and nitrogen are consumed in ground water, microorganisms will typically then use manganese, then ferric iron, then sulfate as the electron acceptors in that order (Stumm and Morgan, 1996). In very "reduced" water, methane gas can be produced. The order in which the electron acceptors are consumed is a function of the amount of energy the reaction can provide to microorganisms. Oxygen is generally consumed first because it supplies the most energy; methane production supplies the least. Instead of organic material, sometimes "reduced" inorganic metals, such as pyrite, can supply electrons. If electron donors are not available, redox reactions will not occur.

Dissolved-oxygen concentrations in ground-water samples from the northern High Plains indicated that the aquifer generally was well oxygenated (table 7). Redox conditions can be categorized as oxic (dissolved oxygen $>1 \mathrm{mg} / \mathrm{L}$ ), post-oxic (dissolved oxygen $<1 \mathrm{mg} / \mathrm{L}$, no hydrogen sulfide present), sulfidic (dissolved oxygen $<1 \mathrm{mg} / \mathrm{L}$, hydrogen sulfide present), or methanogenic (methane present) (Berner, 1981). Redox conditions in the northern High Plains were primarily oxic -141 samples (73 percent) were oxic, 47 samples (24 percent) were post-oxic, and 4 samples ( 2 percent) were sulfidic. The number of methanogenic samples is unknown because methane was not analyzed. The OGAL had the highest median dissolved-oxygen concentration $(7.50 \mathrm{mg} / \mathrm{L})$ and the PLAT had the lowest median dissolved-oxygen concentration $(0.60 \mathrm{mg} / \mathrm{L})$. Dissolved oxygen in the OGAL was significantly larger than the other three units (p-values $<0.10$ ). Concentrations in the SAND were also significantly larger than in the PLAT unit $(\mathrm{p}=0.041)$. Unlike the other units, the majority (66 percent) of samples collected from PLAT were post-oxic. The reducing conditions observed in ground water in the PLAT likely result from the greater abundance of organic matter present in the relatively young river-deposited sediments along the Platte River.
$\mathrm{pH}$

$\mathrm{pH}$ is a measure of the hydrogen ion concentration. $\mathrm{A} \mathrm{pH}$ of 7 is neutral, a pH less than 7 is acidic, and a $\mathrm{pH}$ greater than 7 is basic. $\mathrm{pH}$ can affect the capacity of water to dissolve minerals and trace elements; water that has low $\mathrm{pH}$ is generally more corrosive and will more readily dissolve the minerals and elements from aquifer sediments or plumbing components. $\mathrm{pH}$ also can affect biological processes. The median $\mathrm{pH}$ of the northern High Plains aquifer was near neutral at 7.5. Values ranged from 6.2 to 8.4. Acceptable $\mathrm{pH}$ values for drinking water are 6.5 to 8.5 according to the SDWR established by the USEPA. Only one water sample (CNBR-18) had a pH value outside the acceptable range (6.2). Water collected from the OGAL unit had significantly higher $\mathrm{pH}$ values than the other units (p-values <0.10) (table 7). Also, $\mathrm{pH}$ values in the SAND were significantly higher than in the PLAT ( $\mathrm{p}=0.055)$.

\section{Temperature}

Measuring the temperature of ground water is useful because temperature can influence chemical reactions and biological processes and can be used as an indication of proximity to recharge. Extreme temperatures in ground water reduce its usefulness for drinking-water purposes. The median groundwater temperature of the northern High Plains was $13.4^{\circ} \mathrm{C}$. Temperatures generally increased with depth below the water table ( $r h o=0.479, p=<0.001)$. Water collected from the OGAL had significantly higher temperatures than the other units (p-values < 0.10) (table 7). Differences between the remaining units were not statistically significant.

\section{Specific Conductance}

Specific conductance is the measure of the water's ability to conduct an electric current. Conductance is also indirectly related to the ion concentration in water; as the concentration of charged ions increases in water, the conductance increases 
(Hem, 1985). Because conductance values change with temperature, measurements are reported as the specific conductance by correcting to a standard temperature of 25 degrees Celsius $\left({ }^{\circ} \mathrm{C}\right)$. Specific-conductance values in the northern High Plains ranged from 79.0 to 2,870 microsiemens per centimeter $(\mu \mathrm{S} / \mathrm{cm})$ at $25^{\circ} \mathrm{C}$, with a median of $429 \mu \mathrm{S} / \mathrm{cm}$ at $25^{\circ} \mathrm{C}$. Larger median specific-conductance concentrations were detected in the EAST and PLAT units, and the median specific conductance concentration was much smaller in the SAND unit (table 7). Differences between specific conductance concentrations were significantly different between all units ( $p$-values $<0.10$ ) except between the EAST and PLAT units.

\section{Depth to Water}

Depth to water in the northern High Plains aquifer was variable and ranged from 0 to about $272 \mathrm{ft}$ below land surface (Appendix 1). Median ground-water levels were shallower in the SAND and the PLAT units than in the OGAL or EAST units (table 7). Depths to water were significantly smaller in the PLAT than the other units ( $p$-values $<0.10$ ). Differences between the other units were not significantly different. Water samples were collected at variable depths within the aquifer. The distance of the well-screen midpoint from the water table surface ranged from $6.00 \mathrm{ft}$ above the water table to $615.36 \mathrm{ft}$ below the water table. The median depth of well-screen midpoints below the water table was significantly less in the PLAT than the other units (p-values <0.10) (table 7). Differences between the other units were not significantly different.

\section{Nitrogen and Phosphorus Compounds}

Nitrogen and phosphorus compounds can exist in different forms in water. Water samples collected for this study were analyzed for nitrite plus nitrate as nitrogen, nitrite as nitrogen, and ammonia as nitrogen. Ammonia plus organic nitrogen as nitrogen concentrations were determined in the OGAL, EAST, and PLAT units. Phosphorus was measured in the form of orthophosphate as phosphorus. Because the analytical results for nitrite showed it to be negligible in sampled water, nitrite plus nitrate concentrations are composed almost entirely of nitrate. Therefore, the concentration of nitrite plus nitrate will be referred to as "nitrate" in this report.

Nitrogen and phosphorus are essential plant nutrients; however, excessive amounts can be harmful to the environment and human health. The USEPA has determined that nitrate concentrations greater than $10 \mathrm{mg} / \mathrm{L}$ in drinking water may present potential health risks to humans (U.S. Environmental Protection Agency, 2004). As a result, nitrate concentrations have been extensively studied in the High Plains aquifer. Historically, nitrate concentrations in ground water have been increasing since the 1970s (Litke, 2001). The median nitrate concentration between 1930 and
1970 in the entire High Plains aquifer (northern, central, and southern) was $1.7 \mathrm{mg} / \mathrm{L}$, and the median nitrate concentration in the 1980s and 1990s was $3.2 \mathrm{mg} / \mathrm{L}$. Dissolved phosphorus concentrations are typically small in ground water because phosphorus has a very low solubility and readily sorbs to soil particles. Therefore, most of the following discussion will focus on nitrogen compounds.

Sources of nitrogen and phosphorus include fertilizers, human or animal waste, decay of plant material, the atmosphere, and certain minerals. The average nitrogen application rate from fertilizer and manure in the northern High Plains was 41 pounds of nitrogen per acre per year (table 3 ). Animal feedlots provide another potential source of nitrogen to ground water. Elliott and others (1972) suggest that feedlot management can affect the amount of nitrogen a feedlot will contribute to deep soil profiles. They found that as long as a feedlot was in use, the soil underneath the feedlot remained firmly packed. The packed soil reduced infiltration rates and the soil profile remained anaerobic to assist denitrification. In these cases, feedlots contributed less nitrogen to the deeper soil profile than cropped fields where regular tilling loosens soil and mixes nitrogen. Nitrogen from decayed plants can be concentrated in soils and mobilized when the soil is first tilled. Precipitation or irrigation water moves more easily through cultivated soils than through soils covered with natural vegetation. Dissolved nitrogen will move with the infiltrating water to the saturated zone. Individual septic systems also can contribute nitrogen to ground water, but the low areal density of septic systems in most places probably limits the amount of nitrogen added to ground water from septic systems relative to other sources. However, septic systems could act as point sources and provide a locally important source of nitrate; in particular, many rural households with domestic wells have septic systems nearby. Precipitation contributes an average annual nitrogen load of 3.5 pounds per acre in the High Plains study area (National Atmospheric Deposition Program, 2000). This annual load is equivalent to a concentration of $0.7 \mathrm{mg} / \mathrm{L}$ nitrogen per acre per year if all nitrate in precipitation reached ground water without reacting with soils.

Because nitrate can be present as a result of natural processes as well as human activities, it is useful to know the background nitrate concentration in ground water from natural sources. This background nitrate concentration for ground water considered to be unaffected by human activities can be difficult to determine and may differ regionally. The NAWQA Program analyzed nitrate data from ground-water samples collected throughout the Nation in areas thought to be minimally affected by human activities (Mueller and Helsel, 1996). Analysis of those data indicated that background nitrate concentrations generally were less than $2.0 \mathrm{mg} / \mathrm{L}$. In another national study evaluating nitrate, concentrations of more than $3 \mathrm{mg} / \mathrm{L}$ were considered to be indicative of human impacts (Madison and Brunett, 1985). Gosselin (1991) suggested that background nitrate concentrations were 
less than $3.0 \mathrm{mg} / \mathrm{L}$ in northeast Nebraska. Becker and others (2002) collected 74 ground-water samples in the central High Plains and found that nitrate concentrations in water with no detectable tritium ranged from 1.07 to $3.98 \mathrm{mg} / \mathrm{L}$, with a median of $2.04 \mathrm{mg} / \mathrm{L}$. For purposes of this study, nitrate concentrations greater than $4 \mathrm{mg} / \mathrm{L}$ were considered to be affected by human activities. Nitrate concentrations less than $4 \mathrm{mg} / \mathrm{L}$ were considered to be unaffected when the water was oxic. At some sites, nitrate concentrations were less than $4 \mathrm{mg} / \mathrm{L}$ and dissolved-oxygen concentrations were less than $1 \mathrm{mg} / \mathrm{L}$ (indicating conditions where denitrification could be occurring). It could not be determined whether water was affected or unaffected at these sites because nitrate concentrations could have initially been more than $4 \mathrm{mg} / \mathrm{L}$ and then reduced by denitrification.

The median nitrate concentration in the northern High Plains was $1.93 \mathrm{mg} / \mathrm{L}$. Median nitrate concentrations were largest in the PLAT $(2.84 \mathrm{mg} / \mathrm{L})$, followed by the OGAL $(2.04 \mathrm{mg} / \mathrm{L})$, EAST $(1.92 \mathrm{mg} / \mathrm{L})$, and SAND $(0.73 \mathrm{mg} / \mathrm{L})$ units (table 8). Nitrate concentrations were significantly lower in the SAND than in the OGAL ( $\mathrm{p}=0.002)$ or PLAT $(\mathrm{p}=0.084)$ units. Differences between other units were not statistically significant. Thirty-seven (19 percent) samples collected in the northern High Plains had nitrate concentrations greater than $4 \mathrm{mg} / \mathrm{L}$, indicating that those samples included ground water that was affected by human activities. Ten ( 38 percent) samples collected from the PLAT, six (20 percent) samples from the EAST, five (19 percent) samples collected from the SAND, and 16 (15 percent) samples from the OGAL had nitrate concentrations greater than $4 \mathrm{mg} / \mathrm{L}$ (fig. 8). Twelve samples (6 percent) exceeded the USEPA MCL in the northern High Plains. Eight (31 percent) of the water samples collected from the PLAT, one (4 percent) of the samples collected from the SAND, and three (3 percent) of the samples collected from the OGAL exceeded the USEPA MCL. Geographically, nitrate concentrations more often exceeded the USEPA MCL in areas near major streams (fig. 8). These areas were generally converted to cropland earlier than other parts of the study area because settlement occurred first along river valleys with fertile soils and surface water available for irrigation.
Concentrations of dissolved oxygen in ground water can affect concentrations of nitrogen compounds. Nitrite, ammonia, and organic nitrogen are more stable in post-oxic conditions. Conversely, nitrate is very soluble in oxic water and, therefore, can readily be transported to the aquifer with oxygenated recharge water. Nitrate concentrations were positively correlated with dissolved-oxygen concentrations $($ rho $=0.536, p=<0.001)$, but ammonia $(r h o=-0.420, p=<0.001)$ and nitrite $(\mathrm{rho}=-0.280, \mathrm{p}=<0.001)$ were negatively correlated with dissolved-oxygen concentrations.

Nitrate concentrations were affected by hydrogeologic and land-use factors. Nitrate concentrations decreased as the depth below the water table from which a sample was collected increased (rho $=-0.350, \mathrm{p}=<0.001)$. Nitrate concentrations also were positively correlated with dissolved solids (rho=0.259, $\mathrm{p}=<0.001)$, sulfate ( $\mathrm{rho}=0.207, \mathrm{p}=0.004)$, and chloride (rho $=0.450, \mathrm{p}=<0.001$ ) concentrations, indicating that the factors that affect these constituents in the aquifer may also influence nitrate. Likely factors are the application of agricultural chemicals at the land surface, application of irrigation water, thickness of the unsaturated zone, permeability of soil and aquifer sediments, and concentrating of chemicals in the soil through evapotranspiration.

Nitrite was only detected in 14 samples (7 percent) in the northern High Plains. The largest nitrite concentration was $0.172 \mathrm{mg} / \mathrm{L}$. Nitrite was detected in 10 (37 percent) of the PLAT samples, three (10 percent) of the EAST samples, one (1 percent) of the OGAL samples, and none of the SAND samples. Ammonia was detected in 23 (10 percent) of the samples in the northern High Plains. In general, ammonia was only present when neither nitrate nor nitrite was detected. Ammonia was detected more often in the EAST (23 percent), followed by the SAND (15 percent), PLAT (15 percent), and the OGAL (5 percent). The largest ammonia concentration $(1.02 \mathrm{mg} / \mathrm{L})$ was detected in the EAST unit. Orthophosphate was detected at 67 percent of the sampled sites. Concentrations ranged from less than 0.02 to $0.90 \mathrm{mg} / \mathrm{L}$, with a median of $0.04 \mathrm{mg} / \mathrm{L}$. Median concentrations were largest in the SAND and smallest in the OGAL (table 8).

Table 8. Median concentrations of nitrogen and phosphorus compounds in the northern High Plains aquifer, 1997, 2002-04.

[Constituents are dissolved. Units are milligrams per liter; OGAL, Ogallala Formation; EAST, Eastern Nebraska; SAND, Sand Hills; PLAT, Platte River Valley; USEPA, U.S. Environmental Protection Agency; N, nitrogen; NA, not analyzed; --, no standard has been determined; LTHA, Lifetime Health Advisory; MCL, Maximum Contaminant Level; <, less than; P, phosphorus]

\begin{tabular}{|c|c|c|c|c|c|c|}
\hline Constituent or property & OGAL & EAST & SAND & PLAT & $\begin{array}{l}\text { Northern } \\
\text { High Plains }\end{array}$ & $\begin{array}{l}\text { USEPA drinking-water } \\
\text { standard / type of standard }{ }^{1}\end{array}$ \\
\hline Ammonia as $\mathrm{N}$ & $<0.04$ & $<0.04$ & $<0.04$ & $<0.04$ & $<0.04$ & 30 / LTHA \\
\hline Nitrite as $\mathrm{N}$ & $<0.01$ & $<0.01$ & $<0.01$ & $<0.01$ & $<0.01$ & $1 / \mathrm{MCL}$ \\
\hline Orthophosphate as P & 0.04 & 0.10 & 0.16 & 0.14 & 0.04 & -- \\
\hline
\end{tabular}

${ }^{1}$ Source: U.S. Environmental Protection Agency, 2004. 

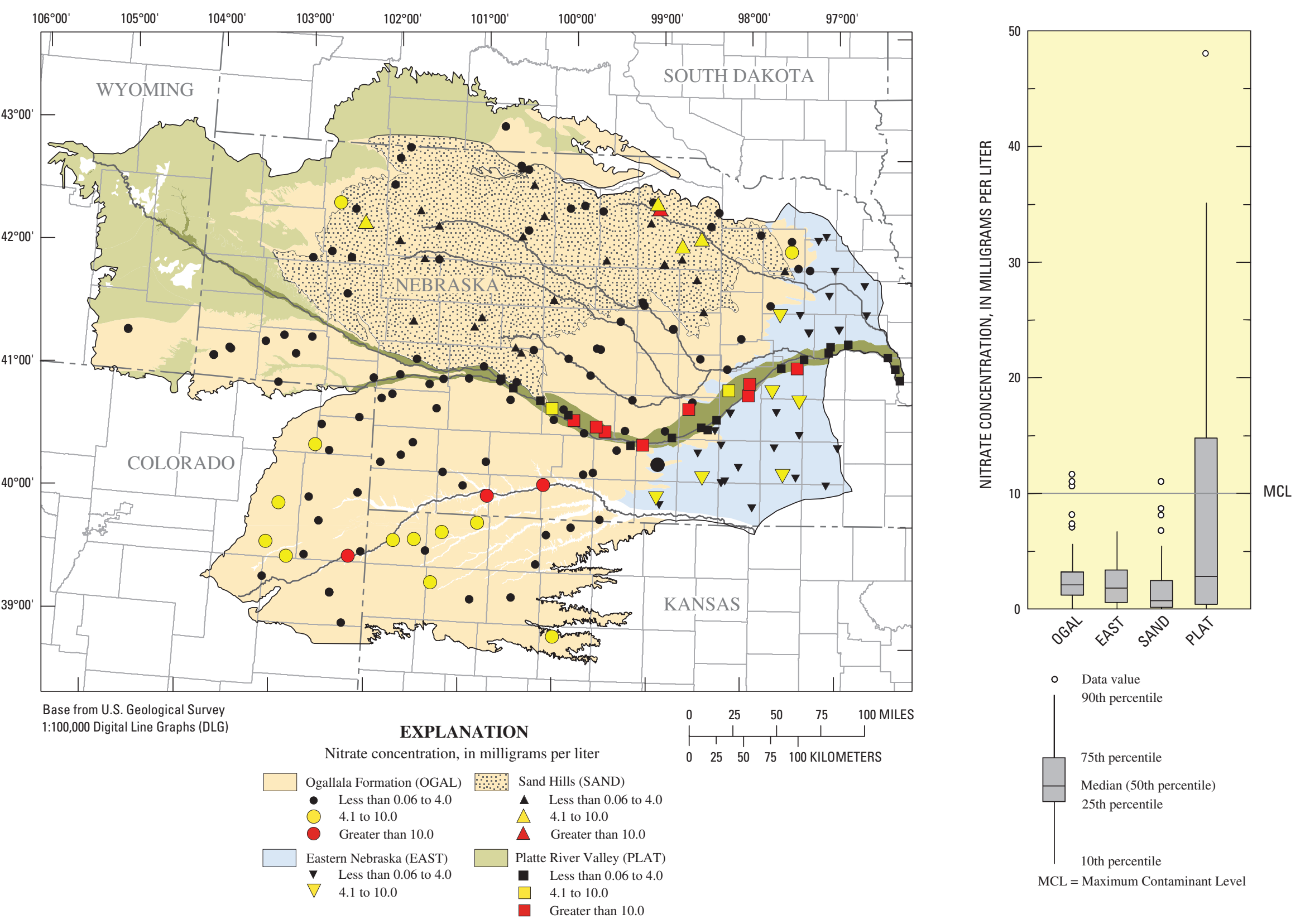

Figure 8. Distribution of nitrate concentrations by hydrogeologic unit in the northern High Plains aquifer, 1997, 2002-04. 


\section{Pesticides and Pesticide Degradates}

The widespread use of pesticides in the United States began after World War II. Since then, the amount of applied pesticides has steadily increased - total use of herbicides and insecticides on crops and pastureland grew from 190 million pounds of active ingredient in 1964 to 660 million pounds of active ingredient in 2000 (Gilliom and others, 1985; Kiely and others, 2004). When pesticides migrate past the soil profile where they are applied at the land surface, ground-water quality can be degraded and can pose potential health hazards.

Some factors that affect the mobility of pesticides from the land surface to ground water are physical barriers to water flow such as clay layers, redox conditions, organic matter, and the chemical properties of a pesticide. Redox conditions can affect the mobility of pesticides; especially pesticide degradates (Barbash and Resek, 1996). Although degradation of a pesticide can increase, decrease, or cause no change in mobility, pesticide degradates generated in oxic conditions are generally more water soluble (and less toxic) than parent compounds. For example, deethylatrazine is less likely to sorb to soils than its parent compound atrazine. Pesticides and other organic compounds may be attracted to solid organic matter or dissolved organic matter, including DOC. When pesticides sorb to solid organic matter, solubility will decrease. Conversely, when pesticides are attracted to dissolved organic matter, the solubility of the pesticide can increase (Barbash and Resek, 1996, p. 188). Chemical properties of a pesticide that can affect the movement and availability are the soil half-life, the sorption coefficient, and water solubility. The soil half-life is the time it takes for a pesticide to degrade to one-half of its original concentration. A pesticide is generally considered to be nonpersistent if it degrades to one-half of its original concentration in less than 30 days. The sorption coefficient measures the tendency to bind to soil particles, thereby limiting the movement of a pesticide; the larger the sorption coefficient, the greater the tendency to bind to soil. Water solubility is the amount of pesticide that will dissolve in a quantity of water. The chemical properties of most pesticides that were analyzed for this study have been published (Wauchope and others, 1992; Augustijn-Beckers and others, 1994).

Pesticides can migrate to ground water as the original compound or can break down into degradate products. Water samples were analyzed for 95 pesticides and 17 pesticide degradates. They were selected for analysis by the NAWQA Program on the basis of national agricultural and nonagricultural use, potential environmental effects, and chemical properties that allow analysis by gas chromatography/mass spectrometry. General information about the pesticides and degradates is shown in Appendix 2. Figure 9 shows all pesticide compound concentrations above and below the highest laboratory reporting level. Only the pesticide concentrations not qualified with a "less than" remark code are presented. For purposes of this report, a pesticide concentration was only identified as a detection if the value was at or above the highest LRL reported for that pesticide compound.
Nine pesticides and two pesticide degradates were detected in the northern High Plains aquifer. All pesticide concentrations were well below the applicable USEPA MCLs. The herbicide atrazine and its degradation product deethylatrazine were detected most frequently (in water from 33 and 38 wells respectively). Detected atrazine concentrations ranged from 0.007 to $0.691 \mu \mathrm{g} / \mathrm{L}$, and deethylatrazine was detected at estimated concentrations ranging from 0.006 to $0.802 \mu \mathrm{g} / \mathrm{L}$. Other pesticide compounds detected were simazine (seven wells), metolachlor (five wells), prometon (three wells), 2-hydroxyatrazine (two wells), diuron (two wells), tebuthiuron (one well), 2,4-D methyl ester (one well), bentazon (one well), and diazinon (one well). Forty-three of the 192 sampled wells (22 percent) had one or more pesticides or pesticide degradates detected (fig. 10).

Most of the pesticide detections were from water samples collected in the PLAT unit -57 of the 94 pesticide detections in the northern High Plains were in the PLAT. Water from 21 wells (78 percent) sampled in the PLAT unit had one or more pesticide compounds detected. Three pesticides were detected in more than 25 percent of the wells in the PLAT21 wells (78 percent) had detectable atrazine, 20 wells (74 percent) had detectable deethylatrazine, and 7 wells (26 percent) had detectable simazine. Other pesticides detected in the PLAT were metolachlor (three wells), prometon (three wells), diuron (one well), bentazon (one well), and tebuthiuron (one well). The EAST unit had the next highest number of pesticide detections (16 detections). Water from nine wells (30 percent) had at least one pesticide detected. Atrazine was detected at six wells (20 percent), deethylatrazine was detected at seven wells (23 percent), and 2-hydroxyatrazine, metolachlor, and diazinon were detected at one well each. Although more than three times as many samples were collected from the OGAL than other units, only 13 of the 94 pesticide detections were in water samples from that unit. Water from nine wells (8 percent) in the OGAL had at least one pesticide detected. Five different pesticide compounds were detected-atrazine (three wells), deethylatrazine (seven wells), 2-hydroxyatrazine (one well), diuron (one well), and 2,4-D methyl ester (one well). Eight of the 94 pesticide detections were in the SAND, and water from four wells (15 percent) had at least one pesticide detected. Three pesticide compounds were present at detectable levels in that unit—deethylatrazine (four wells), atrazine (three wells), and metolachlor (one well).

The number of pesticide detections was affected by hydrogeologic and land-use factors. The number of pesticide detections in a sample was inversely correlated with depth to water $(\mathrm{rho}=-0.319, \mathrm{p}=<0.001)$ and the depth below the water table that a sample was collected $(\mathrm{rho}=-0.390, \mathrm{p}=<0.001)$. The number of detections in a sample was positively correlated with nitrate $(\mathrm{rho}=0.349, \mathrm{p}=<0.001)$, dissolved solids (rho $=0.441, \mathrm{p}=<0.001)$, sulfate $(\mathrm{rho}=0.496, \mathrm{p}=<0.001)$, and chloride (rho $=0.525, \mathrm{p}=<0.001$ ) concentrations, indicating that the factors that affect these constituents in the aquifer may have a similar effect on pesticides. 

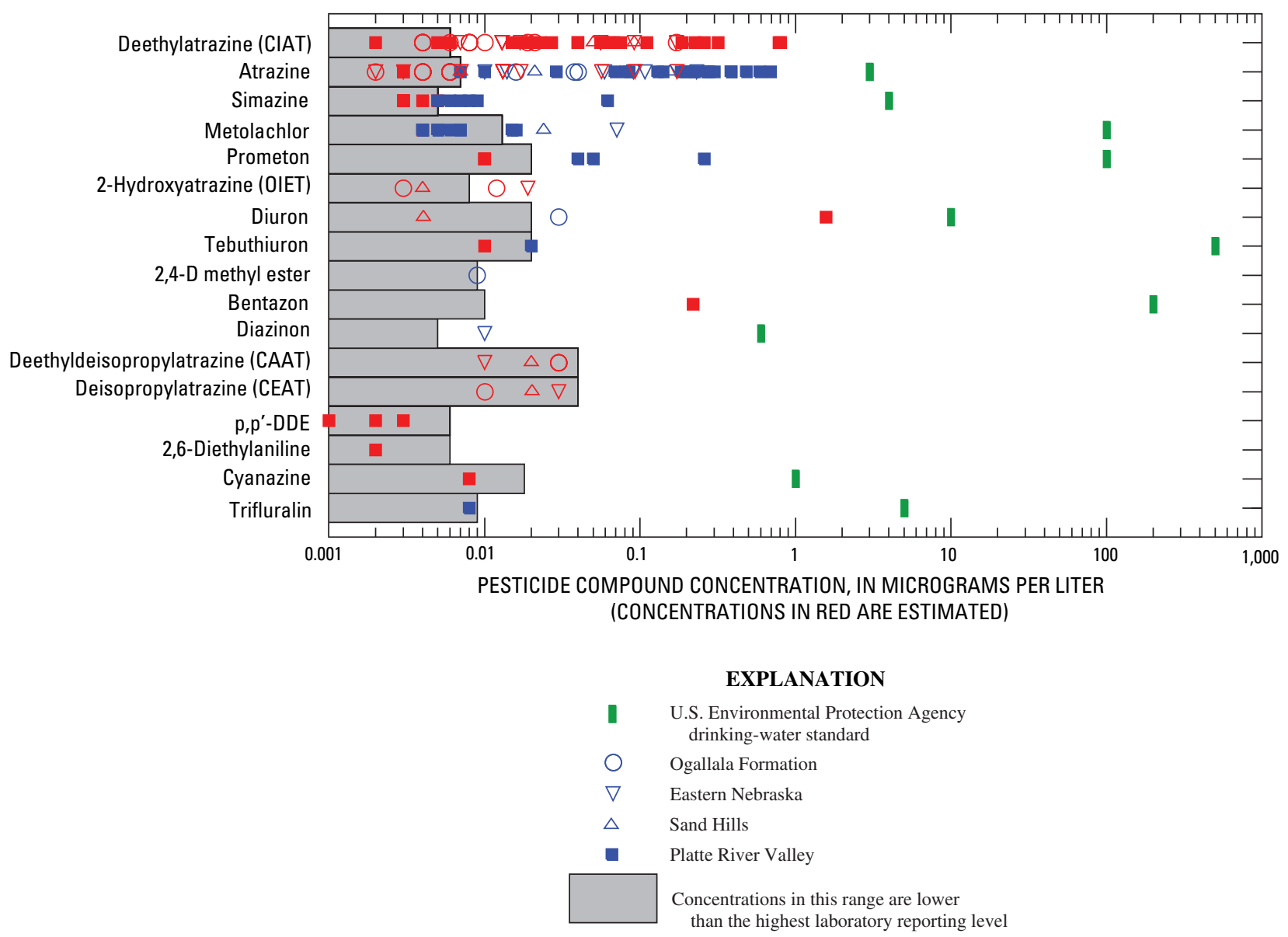

Figure 9. Pesticide compound concentrations in the northern High Plains aquifer, 1997, 2002-04.

\section{Dissolved Solids, Major Ions, and Trace Elements}

Ground water is never pure and generally contains a wide variety of dissolved solids and gases. Major ions and trace elements are discussed with dissolved solids because they generally account for the bulk of dissolved solids in a water sample. The primary major ions that contribute to dissolved-solids concentrations are bromide, calcium, carbonate alkalinity, chloride, fluoride, magnesium, potassium, silica, sodium, and sulfate. Nitrogen compounds and organic material also can be substantial components of dissolvedsolids concentrations. Water also commonly contains trace amounts of many minor elements such as aluminum, arsenic, copper, iron, lead, selenium, and uranium.

Hydrogeologic, climatic, and land-use factors can affect the availability of minerals for dissolution and eventual transport to ground water. When water comes in contact with soil or rock minerals, the solid minerals dissolve until the water becomes saturated or the minerals are depleted. The dissolution rate of the various minerals depends on their individual solubility and environmental conditions. Mineral concentrations in soil generally increase as evapotranspiration rates increase. As dilute water is selectively evaporated or used by plants, minerals are left behind. Over time, the concentration of minerals in the soil steadily increases and is available to be leached into the ground water. Underlying bedrock units that have hydraulic connection with the High Plains aquifer can affect dissolved-solids concentrations (McMahon and others, 2004a). Salinity in the lower part of an aquifer can increase if the bedrock unit below the aquifer contains soluble deposits of high mineral content and ground-water flow paths are upwards toward the aquifer. This condition potentially could exist in some parts of the northern High Plains study area. Farming practices can increase dissolved-solids concentrations in ground water. Irrigation water not used by crops can leach minerals from the soil profile and unsaturated sediments into the ground water. When this occurs, dissolved-solids concentrations increase near the top of the aquifer. In addition, some fertilizers and soil amendments contain minerals such as calcium, chloride, magnesium, potassium, and sulfate that can be leached. Indirect effects of agricultural amendments on dissolved-solids, major-ion, and trace-element concentrations include lowered $\mathrm{pH}$, increased rate of aquifer sediment dissolution, and changes to ion-exchange reactions (Böhlke, 2002). 

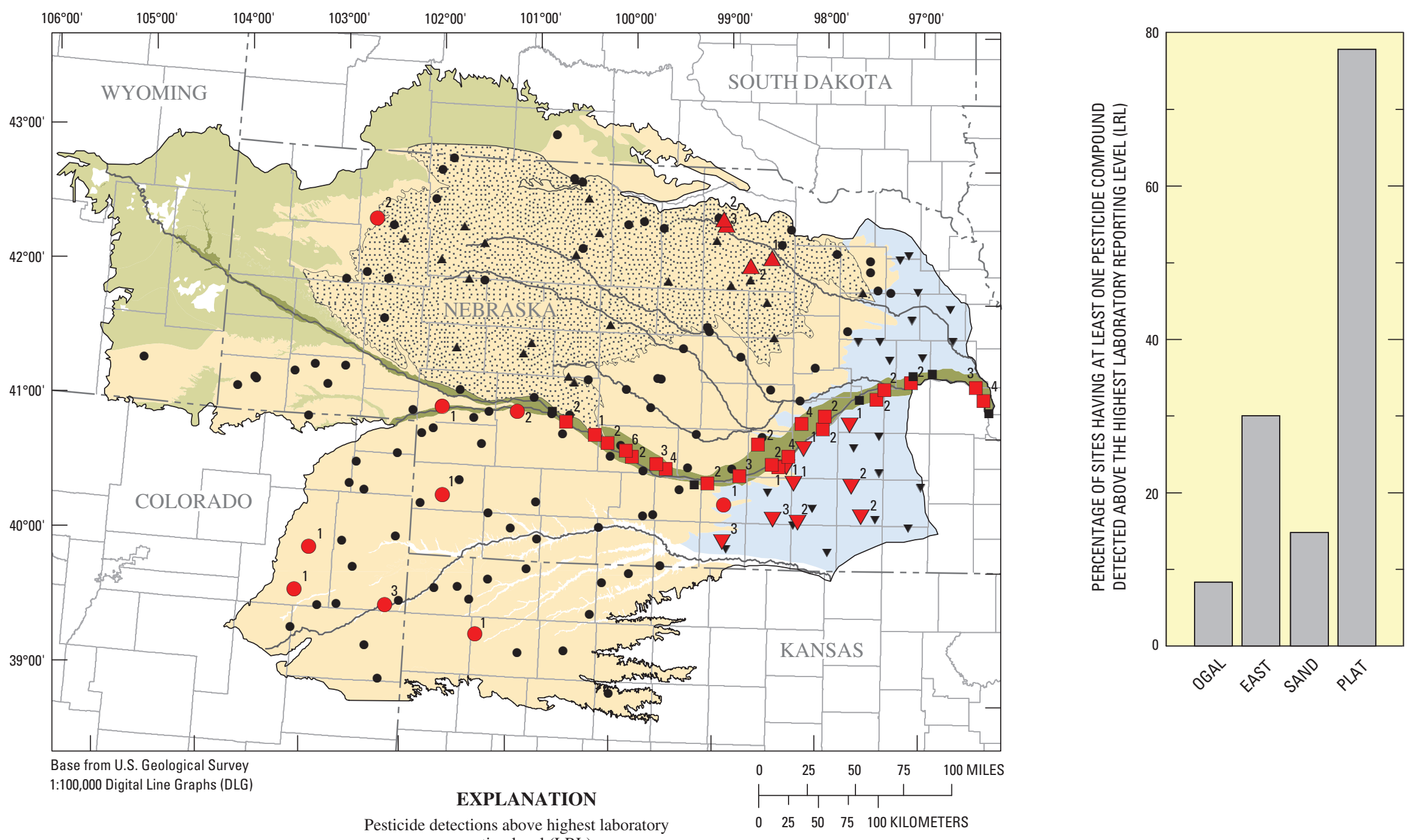

Pesticide detections above highest laboratory reporting level (LRL)

Figure 10. Distribution of pesticide detections by hydrogeologic unit in the northern High Plains aquifer, 1997, 2002-04. 


\section{Dissolved Solids}

The concentration of dissolved solids is an indicator of ground-water quality. High concentrations of dissolved solids can limit the use of ground water for drinking water, application to crops, and industrial purposes. Although large concentrations of dissolved solids generally are not hazardous to health, the USEPA has set the nonenforceable SDWR for dissolved solids at $500 \mathrm{mg} / \mathrm{L}$. This standard was set to minimize mineral deposits, discolored water, staining, and salty taste (U.S. Environmental Protection Agency, 2004). Livestock also are sensitive to large dissolved-solids concentrations; however, most livestock can tolerate much larger concentrations than humans. Irrigation water containing large concentrations of dissolved solids can be harmful to sensitive crops and is of most concern in arid regions where precipitation is insufficient to provide low-salinity water to crops (Hergert and Knudsen, 1977; Hoffman, undated). Dissolved boron, chloride, and sodium are particularly toxic to plants.

Dissolved-solids concentrations, reported as total solids residue on evaporation, in the northern High Plains ranged from 80 to 2,190 mg/L, with a median of $290 \mathrm{mg} / \mathrm{L}$. The PLAT had the highest median dissolved-solids concentration $(440 \mathrm{mg} / \mathrm{L})$, and the SAND had the lowest median dissolvedsolids concentration (159 mg/L) (table 9). Twenty-four of the samples (13 percent) collected from the northern High Plains had dissolved-solids concentrations greater than the USEPA SDWR. Nineteen of those 24 samples were in either the EAST or PLAT unit. Concentrations among all units were significantly different $(\mathrm{p}=<0.10)$ except between the EAST and PLAT units.

Hydrogeologic and land-use variables affected dissolved-solids concentrations. Dissolved-solids concentrations decreased with increased depth below water table $(\mathrm{rho}=-0.203, \mathrm{p}=0.005)$ and were positively correlated with chloride concentrations ( $\mathrm{rho}=0.756, \mathrm{p}=<0.001$ ), indicating that evaporative processes have concentrated dissolved solids in the subsoil, which may be contributing to concentrations in ground water. Dissolved-solids concentrations were significantly larger $(\mathrm{p}=<0.001)$ in samples affected by agricultural activities (nitrate concentrations greater than $4 \mathrm{mg} / \mathrm{L}$ or at least one detectable pesticide compound). Concentrations in samples affected by agriculture ranged from 164 to $2,190 \mathrm{mg} / \mathrm{L}$, with a median of $394 \mathrm{mg} / \mathrm{L}$; concentrations in unaffected samples ranged from 80 to $964 \mathrm{mg} / \mathrm{L}$, with a median of $257 \mathrm{mg} / \mathrm{L}$. Dissolved-solids concentrations were positively correlated with nitrate ( $r h o=0.259, \mathrm{p}=<0.001$ ), providing further evidence that agricultural practices affect dissolved-solids concentrations.

\section{Major lons}

When elements dissolve in water, they dissociate into either positively charged ions (cations) or negatively charged ions (anions). The major cations in ground water typically are calcium, magnesium, potassium, and sodium. The major anions in ground water typically are carbonate alkalinity (reported as calcium carbonate $\left[\mathrm{CaCO}_{3}\right]$ equivalent), chloride, fluoride, and sulfate. When nitrate is present in substantial quantities, it can also be a major anion. The total electrical charge (or milliequivalents) of all cations and anions in a solution must balance to maintain electrical neutrality. One way to represent the relative percentage of the major ions in water is to plot them on a trilinear diagram. Figure 11 shows trilinear diagrams of the major-ion compositions for the samples collected in the four hydrogeologic units. These diagrams plot the relative percentages of total milliequivalents per liter of major ions for many samples at once. A cation or anion is referred to as "dominant" if it accounts for more than 60 percent of the total cations or anions. The dominant cation was most commonly calcium and the dominant anion was most commonly carbonate alkalinity, principally in the form of bicarbonate $\left(\mathrm{HCO}_{3}^{-}\right)$. Many samples also had no dominant cation or anion but had nearly equal mixtures of more than one cation or anion. In a few samples, the dominant anion was sulfate (five samples), chloride (one sample), or nitrate (one sample). The five samples with sulfate as the dominant anion were from the PLAT unit or within several miles of the Platte River. The sample (NOS-1017) dominated by chloride was collected from the OGAL unit in the western part of the study area where precipitation is low. The sample (CNBR-18) dominated by nitrate was collected from a shallow well (19 feet deep) in the PLAT unit. Median concentrations of individual ions are summarized in table 9 . Water in eight samples (4 percent) exceeded the USEPA SDWR of $250 \mathrm{mg} / \mathrm{L}$ for sulfate concentrations. Most of the samples that exceeded the sulfate SDWR were in the PLAT unit. All other major-ion concentrations were considered suitable for drinking-water purposes.

To examine the effects of agricultural practices on the relative percentages of major ions, trilinear diagrams for samples containing agricultural chemicals (at least one pesticide compound detected and[or] nitrate equal to or greater than $4 \mathrm{mg} / \mathrm{L}$ ) and samples not containing agricultural chemicals (no pesticides detected and nitrate less than $4 \mathrm{mg} / \mathrm{L}$ with dissolved oxygen more than $1 \mathrm{mg} / \mathrm{L}$ ) were compared (fig. 12). The major-ion composition in water not containing agricultural chemicals (fig. 12, Unaffected) was dominated by calcium and carbonate alkalinity. These sites mostly had similar ion compositions. In contrast, the samples containing agricultural chemicals (fig. 12, Affected) had ion compositions that were more variable. The dominant cation ranged from calcium to sodium plus potassium, and the dominant anion ranged from carbonate alkalinity to either sulfate or chloride, fluoride, and nitrate. The 14 sites where the effect of agriculture was not known (no pesticides detected and nitrate less than $4 \mathrm{mg} / \mathrm{L}$ with dissolved oxygen less than $1 \mathrm{mg} / \mathrm{L}$ ) had similar major-ion chemistry as the samples unaffected by agricultural chemicals. Therefore, these samples also may have been primarily unaffected by agricultural activities. 
Table 9. Median concentrations of major ions, trace elements, dissolved organic carbon, and radon in the northern High Plains aquifer, 1997, 2002-04.

[Constituents are dissolved. OGAL, Ogallala Formation; EAST, Eastern Nebraska; SAND, Sand Hills; PLAT, Platte River Valley; mg/L, milligrams per liter; --, no standard has been determined; SDWR, Secondary Drinking-Water Regulations; NA, not analyzed; MCL, Maximum Contaminant Level; <, less than; $\mu \mathrm{g} / \mathrm{L}$, micrograms per liter; LTHA, Lifetime Health Advisory; pCi/L, picocuries per liter]

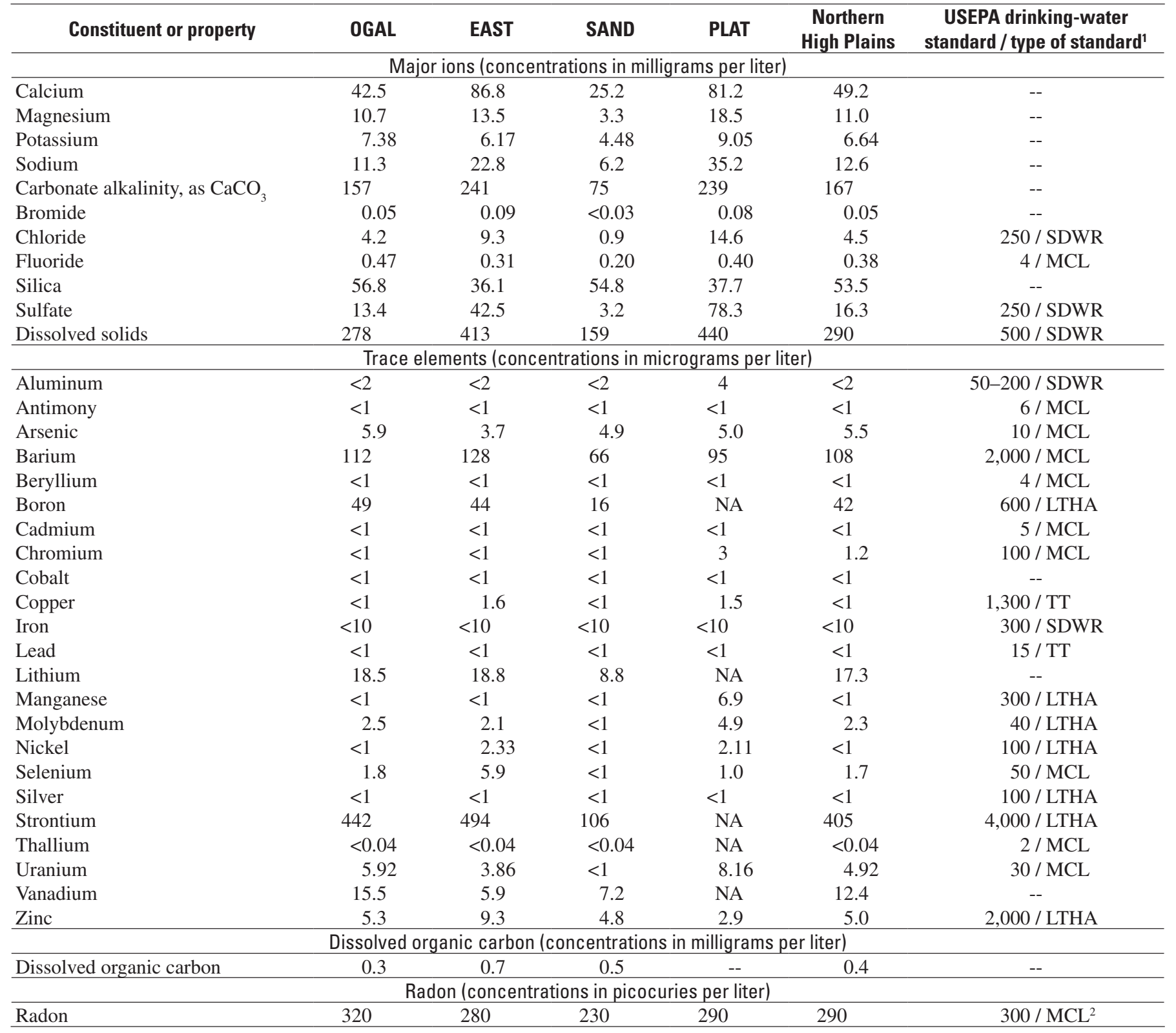

${ }^{1}$ Source: U.S. Environmental Protection Agency, 2004.

${ }^{2}$ Proposed drinking-water standard.

Ion compositions in samples collected near the Platte River indicate that ground water may have contained a component of surface water. Trilinear diagrams for ground-water samples collected from the PLAT unit and surface-water samples collected from the Platte River near Duncan, Nebraska, in 1994 and the Platte River near Grand Island, Nebraska, in 1995 are shown in figure 13. PLAT samples that plot closer to the Platte River water may represent the mixed-ion composition of ground water and surface water.

\section{Trace Elements}

Some trace elements in drinking water are potentially harmful to human health. The fate of trace elements in natural waters is dependent upon many factors including $\mathrm{pH}$, redox conditions, availability of certain ions and minerals, and the presence of organic matter. Most toxic trace elements are generally insoluble when $\mathrm{pH}$ is near neutral. However, some trace elements, such as arsenic, chromium, selenium, and uranium, 

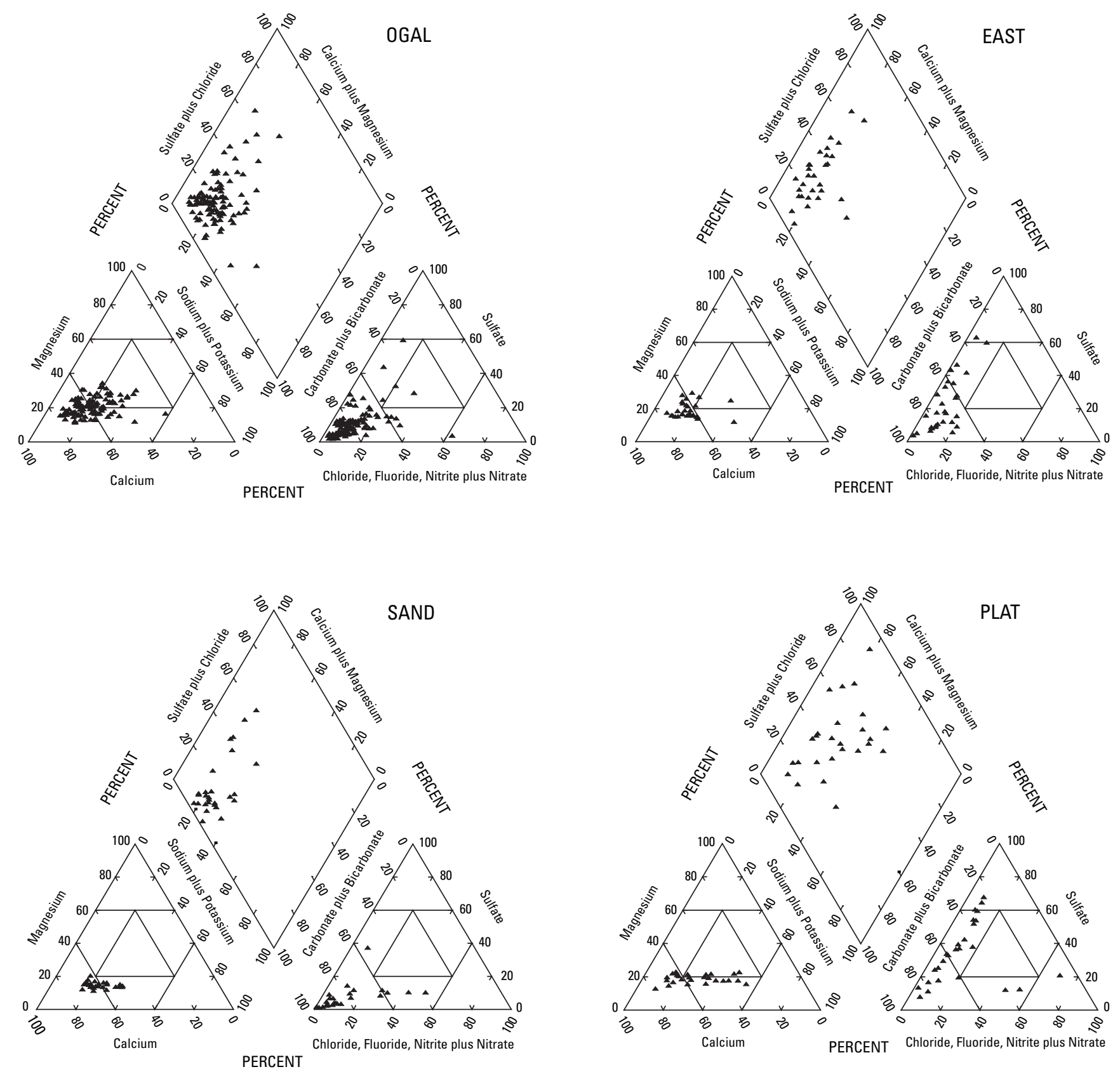

Figure 11. Trilinear diagrams showing the relations between compositions of major ions in water by hydrogeologic unit in the northern High Plains aquifer, 1997, 2002-04.

become more soluble as $\mathrm{pH}$ increases and can be present at large concentrations in water with near-neutral $\mathrm{pH}$. These compounds are therefore more commonly detected in ground water than most trace elements (Smedley and Kinniburgh, 2002).

Arsenic, uranium, and selenium were the only trace elements that exceeded USEPA enforceable (MCL or TT) drinking-water standards in the northern High Plains. Arsenic was the trace element with the highest percentage of samples that had concentrations larger than the drinking-water standard -8 percent of the samples collected exceeded the USEPA MCL of $10 \mu \mathrm{g} / \mathrm{L}$. Consumption of arsenic in drinking water has been linked to an increased risk of cancer as well as cardiovascular, pulmonary, immunological, neurological, and endocrine effects (U.S. Environmental Protection Agency, 2004).

The areal distribution of arsenic concentrations greater than the USEPA MCL is shown in figure 14. The OGAL unit had the highest median $(5.9 \mu \mathrm{g} / \mathrm{L})$ arsenic concentration (table 9), and the SAND unit had the highest 

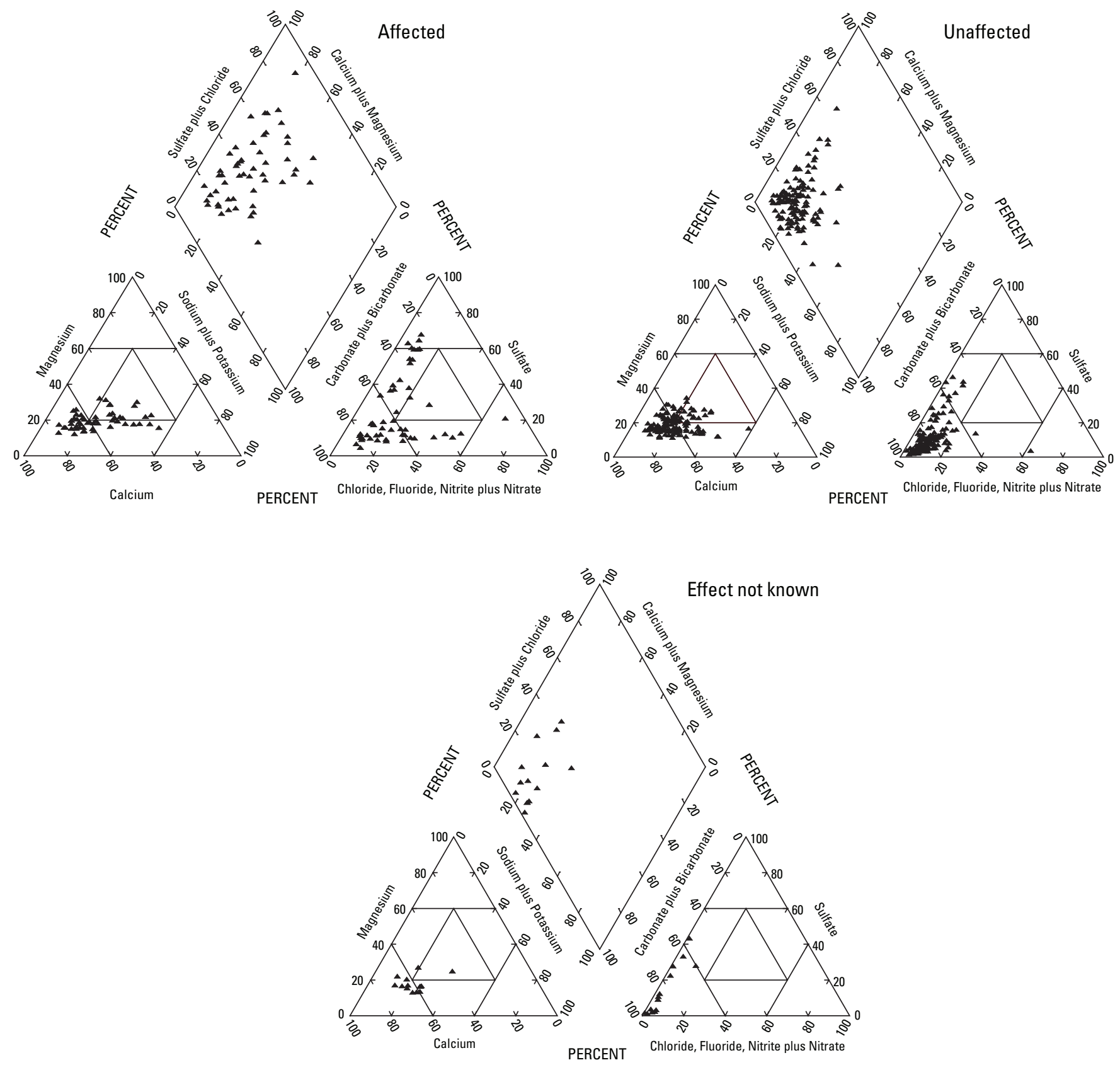

Figure 12. Trilinear diagrams showing the relations between compositions of major ions at sites affected by agricultural activities, sites unaffected by agricultural activities, and sites not known to be affected by agricultural activities in the northern High Plains aquifer, 1997, 2002-04.

percentage (15 percent) of concentrations that exceeded the drinking-water standard. When compared statistically, arsenic concentrations were significantly greater in the OGAL than in the EAST $(p=0.001)$ but were not significantly greater than the PLAT $(\mathrm{p}=0.305)$ or the SAND ( $\mathrm{p}=0.377)$ units. The highest arsenic concentration $(55.6 \mu \mathrm{g} / \mathrm{L})$ was in a water sample collected from the SAND unit (NSS-204). Evaporative processes may have concentrated dissolved arsenic at the land surface near this well based upon consistently high concentrations of many dissolved constituents. The well is located in the western Sand Hills in an area of "closed basin" lakes that have little or no natural drainage.

Sources of arsenic can be natural or anthropogenic. Arsenic is naturally present in some geologic formations-most commonly in marine shales, volcanic rocks, and metamorphic rocks formed from sedimentary deposits. Anthropogenic sources of arsenic include organic and inorganic pesticide compounds. Dissolution of arsenic from natural sources is commonly associated 

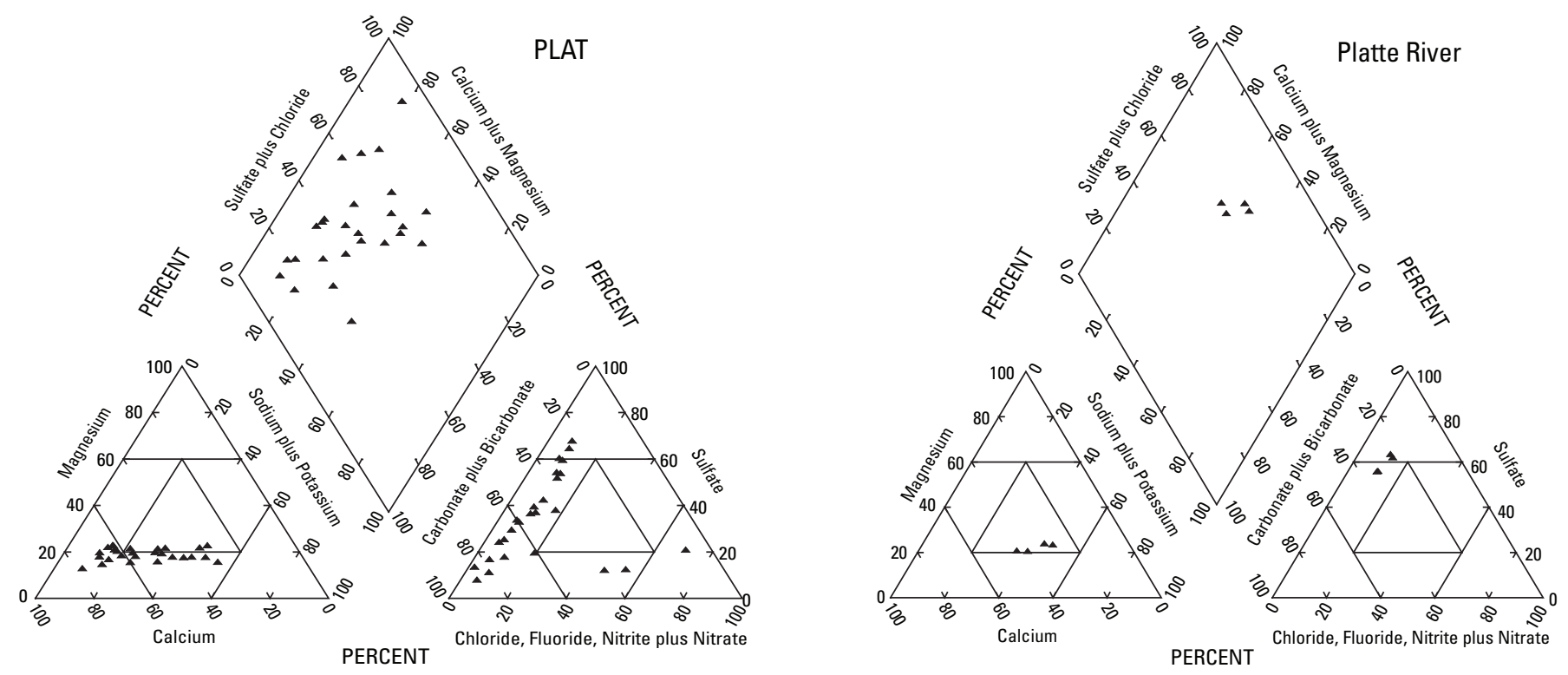

Figure 13. Trilinear diagrams showing the relations between compositions of major ions in samples collected from the Platte River Valley Quaternary unit and samples collected from the Platte River.

with the presence of other elements such as molybdenum, selenium, uranium, and vanadium (Rankama and Sahama, 1950; White and Waring, 1963; U.S. Geological Survey, 1964, 1975; Harshman, 1972). Arsenic concentrations in the northern High Plains were positively correlated with vanadium (rho $=0.467$, $\mathrm{p}=<0.001)$ and molybdenum (rho $=0.271, \mathrm{p}=<0.001)$. These correlations and the relatively uniform concentrations within natural ranges indicate that the sources of arsenic in the northern High Plains are naturally occurring.

The ions and minerals that are likely to be associated with natural sources of arsenic in the northern High Plains can be in marine shales, glacial deposits containing weathered marine shales, volcanic ash, and iron oxides in some sediments, particularly those deposited by streams (Welch and others, 2000). Some bedrock formations in the eastern part of the study area are marine shale; some glacial sediments in the EAST unit originate from marine shales north of the study area. The Brule and Arikaree Formations contain substantial quantities of volcanic ash, and the OGAL contains localized volcanic ash beds.

The underlying bedrock units containing either marine shale or volcanic ash did not appear to affect arsenic concentrations. Forty-nine water samples were collected from wells screened within $50 \mathrm{ft}$ of the underlying Cretaceous (marine shale) bedrock. Those water samples had a median arsenic concentration $(5.0 \mu \mathrm{g} / \mathrm{L})$ similar to water samples collected from wells screened more than $50 \mathrm{ft}$ above the Cretaceous bedrock $(4.8 \mu \mathrm{g} / \mathrm{L})(\mathrm{p}=0.573)$. Volcanic ash in the underlying Brule and Arikaree Formations did not appear to affect arsenic concentrations. Water samples collected from wells screened within $50 \mathrm{ft}$ of the Brule and Arikaree Formations had a median arsenic concentration $(5.80 \mu \mathrm{g} / \mathrm{L})$ similar to those wells screened more than $50 \mathrm{ft}$ above the Brule and Arikaree Formations $(5.70 \mu \mathrm{g} / \mathrm{L})(\mathrm{p}=0.880)$.

Localized volcanic ash deposits are present in the OGAL and may explain the slightly larger median arsenic concentration in that unit. Because the OGAL has a large amount of rhyolitic ash (ash with silica content greater than about 68 weight percent) (Swinehart and others, 1985), larger silica concentrations could indicate areas of volcanic ash deposition. However, arsenic concentrations in the OGAL were not correlated with silica concentrations $(\mathrm{rho}=-0.011, \mathrm{p}=0.909)$. Volcanic ash also typically contains sodium and potassium. Arsenic concentrations in the OGAL were positively correlated with potassium (rho=0.321, $\mathrm{p}=0.001$ ) but not sodium $(\mathrm{rho}=0.144, \mathrm{p}=0.137)$.

The glacial sediments in the EAST unit contain weathered marine shales. These sediments contain iron pyrites that are commonly associated with arsenic. The median arsenic concentration was smallest in the EAST unit (table 9). However, arsenic was positively correlated ( $r h o=0.741, p=0.076$ ) with iron at the seven sites in the EAST where dissolved-oxygen concentrations were less than $1.0 \mathrm{mg} / \mathrm{L}$. This correlation indicates that dissolution of iron oxide is a source of arsenic at these sites. These reduced conditions favor the dissolution of iron oxides and the release of arsenic (Welch and others, 2000). Arsenic was inversely correlated with iron ( $r h o=-0.249, p=0.078)$ when all samples in the northern High Plains with dissolved-oxygen concentrations less than $1.0 \mathrm{mg} / \mathrm{L}$ were examined. Also, arsenic concentrations in neither the EAST unit nor the northern High Plains were significantly correlated with sulfate concentrations. A positive correlation between arsenic and sulfate may indicate pyrite oxidation as a source of arsenic (Welch and others, 2000). 

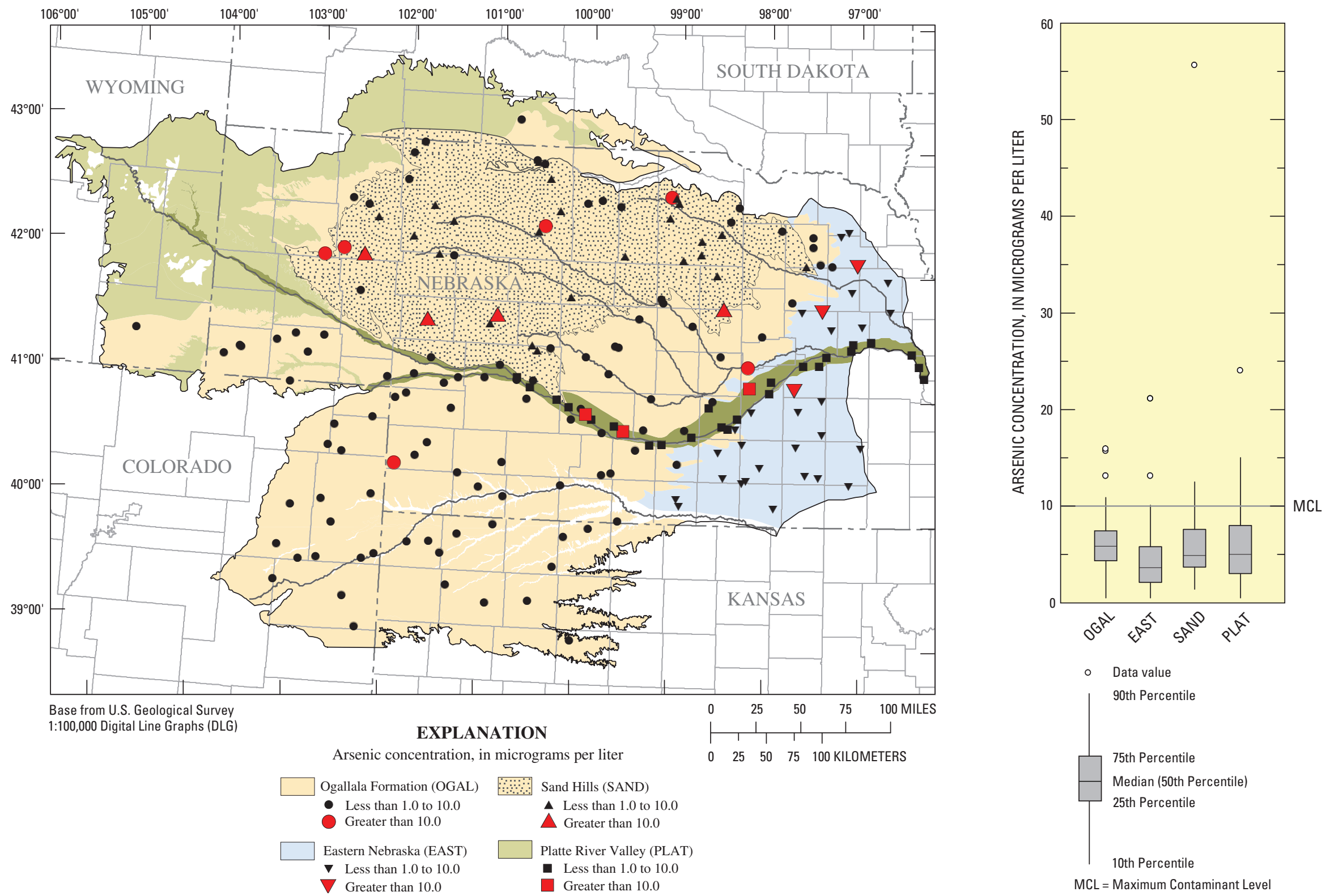

Figure 14. Distribution of arsenic concentrations by hydrogeologic unit in the northern High Plains aquifer, 1997, $2002-04$. 
Water properties can affect arsenic concentrations. As previously mentioned, arsenic becomes more soluble as $\mathrm{pH}$ increases to values greater than about 8. In the northern High Plains, arsenic concentrations were positively correlated with $\mathrm{pH}(\mathrm{rho}=0.273, \mathrm{p}=<0.001)$. The median arsenic concentration of samples with $\mathrm{pH}$ less than 7 was $3.90 \mu \mathrm{g} / \mathrm{L}$, and the median arsenic concentration of samples with $\mathrm{pH}$ greater than 7 was $5.55 \mu \mathrm{g} / \mathrm{L}(\mathrm{p}=0.011)$. Arsenic is soluble in a wide range of redox conditions, albeit as different species (McLean and Bledsoe, 1992). Arsenic in natural waters is primarily present as the arsenite species when water is post-oxic and as the less harmful arsenate species when water is oxic. The relative magnitude of the two arsenic species was not investigated as part of this study.

Six percent of the water samples had uranium concentrations that exceeded the USEPA MCL of $30 \mu \mathrm{g} / \mathrm{L}$. Drinking water containing elevated levels of uranium is associated with an increased risk of cancer and kidney problems (U.S. Environmental Protection Agency, 2004). Uranium concentrations in the northern High Plains aquifer are shown in figure 15. The median uranium concentration was largest in the PLAT $(8.16 \mu \mathrm{g} / \mathrm{L})$ (table 9$)$. Water collected from the PLAT also had the largest percentage of MCL exceedances (26 percent) and the highest overall uranium concentration $(174 \mu \mathrm{g} / \mathrm{L})$ in a single sample. The SAND unit had the lowest uranium concentrations. Only one water sample collected from this unit had detectable uranium. Concentrations in the PLAT were significantly greater than the OGAL $(\mathrm{p}=0.016)$ or EAST $(\mathrm{p}=0.025)$ units. Concentrations in OGAL and EAST units were not significantly different from each other. Concentrations were not compared between the SAND and other units because more than 50 percent of concentrations in the SAND were censored (less than the highest LRL).

Uranium is a radionuclide that is present in some geologic materials. In the northern High Plains, uranium concentrations were positively correlated with dissolved solids ( $\mathrm{rho}=0.609, \mathrm{p}=<0.001$ ) and chloride ( $\mathrm{rho}=0.618, \mathrm{p}=<0.001)$ concentrations as well as concentrations of all other major ions except silica, indicating evaporative concentration as a factor affecting uranium concentrations in ground water. Additionally, the Platte River imports water with high uranium concentrations (over $30 \mu \mathrm{g} / \mathrm{L}$ in some reaches) into the northern High Plains study area. Elevated uranium concentrations in the Platte River are thought to originate from dissolution of uraniferous deposits in the Front Range of the Laramie Mountains (Snow and Spalding, 1994) and Cretaceous shale underlying the South Platte River in Colorado (Breton Bruce, U.S. Geological Survey, written commun., 2005). Elevated uranium in the river may enrich ground-water uranium through canal leakage, application of river water to irrigated crop fields, or mixing between surface water and ground water (Verstraeten and others, 2001). Snow and Spalding (1994) reported that elevated uranium concentrations in ground water in the North Platte, South Platte, and Platte River valleys were more frequently detected in areas that used diverted river water for irrigation. As previously mentioned, ion compositions in water from wells in the PLAT unit provided evidence of mixing with river water.

Marine shales and glacial deposits have been cited as sources of uranium in other regions (Morrow, 2001; Naftz, 1996). The median concentration of uranium in wells screened within $50 \mathrm{ft}$ of the Cretaceous (marine shale) bedrock was $6.85 \mu \mathrm{g} / \mathrm{L}$, and wells screened more than $50 \mathrm{ft}$ above the Cretaceous had a median of $3.53 \mu \mathrm{g} / \mathrm{L}(\mathrm{p}=0.015)$. The EAST is the only unit with a large component of glacial deposits in the northern High Plains. The median uranium concentration was $3.86 \mu \mathrm{g} / \mathrm{L}$, slightly lower than the median uranium concentration of all wells $(4.92 \mu \mathrm{g} / \mathrm{L})$.

Uranium is most soluble under oxidizing conditions. The median uranium concentration was $5.07 \mu \mathrm{g} / \mathrm{L}$ in oxic water, $3.70 \mu \mathrm{g} / \mathrm{L}$ in post-oxic water, and not detected in sulfidic water. Uranium can be persistent in mildly reducing conditions, and concentrations as high as $126.0 \mu \mathrm{g} / \mathrm{L}$ were detected in post-oxic water. A statistical comparison between uranium concentrations in oxic and post-oxic waters indicated that uranium concentrations were not significantly higher $(\mathrm{p}=0.59)$ in oxic waters.

Concentrations of uranium were significantly higher in water affected by agricultural land use (nitrate concentration greater than $4 \mathrm{mg} / \mathrm{L}$ and[or] at least one pesticide compound detection). Uranium concentrations ranged from $<1$ to $174 \mu \mathrm{g} / \mathrm{L}$ with a median of $7.23 \mu \mathrm{g} / \mathrm{L}$ at affected sites and ranged from $<1$ to $91.9 \mu \mathrm{g} / \mathrm{L}$ with a median of $4.70 \mu \mathrm{g} / \mathrm{L}$ at unaffected sites $(\mathrm{p}=<0.001)$. Elevated uranium concentrations were primarily in samples collected from the PLAT unit; the unit with the highest percentage of irrigated cropland. This is likely, at least partially, due to the oxidation and evaporative conditions associated with areas of intense agriculture.

Phosphate fertilizer can contain uranium and might be expected to affect ground-water concentrations. Spalding and Sackett (1972) suggest that phosphate fertilizer applications have resulted in increased uranium in North American rivers. In the PLAT, however, where uranium concentrations in ground water are highest, phosphate fertilizers are not commonly used (Snow and Spalding, 1994). In addition, phosphate fertilizers typically have low solubility in water and will bind to soil particles. When uranium is sorbed to phosphorus, it also has low solubility and will be relatively immobile in the subsurface (Naftz and others, 2002).

Selenium concentrations exceeded the USEPA MCL of $50 \mu \mathrm{g} / \mathrm{L}$ in 1 percent (two samples) of the total samples. In small quantities, selenium is an essential nutrient for good health; however, drinking water containing selenium in concentrations higher than $50 \mu \mathrm{g} / \mathrm{L}$ can potentially cause hair or fingernail loss, damage to the nervous and circulatory systems, or damage kidney and liver tissue (U.S. Environmental Protection Agency, 2004). Natural sources of selenium are soils and aquifer materials. Human sources of selenium include uranium, bentonite, and coal-mining waste products, oil refinery wastewater, and irrigation wastewater 

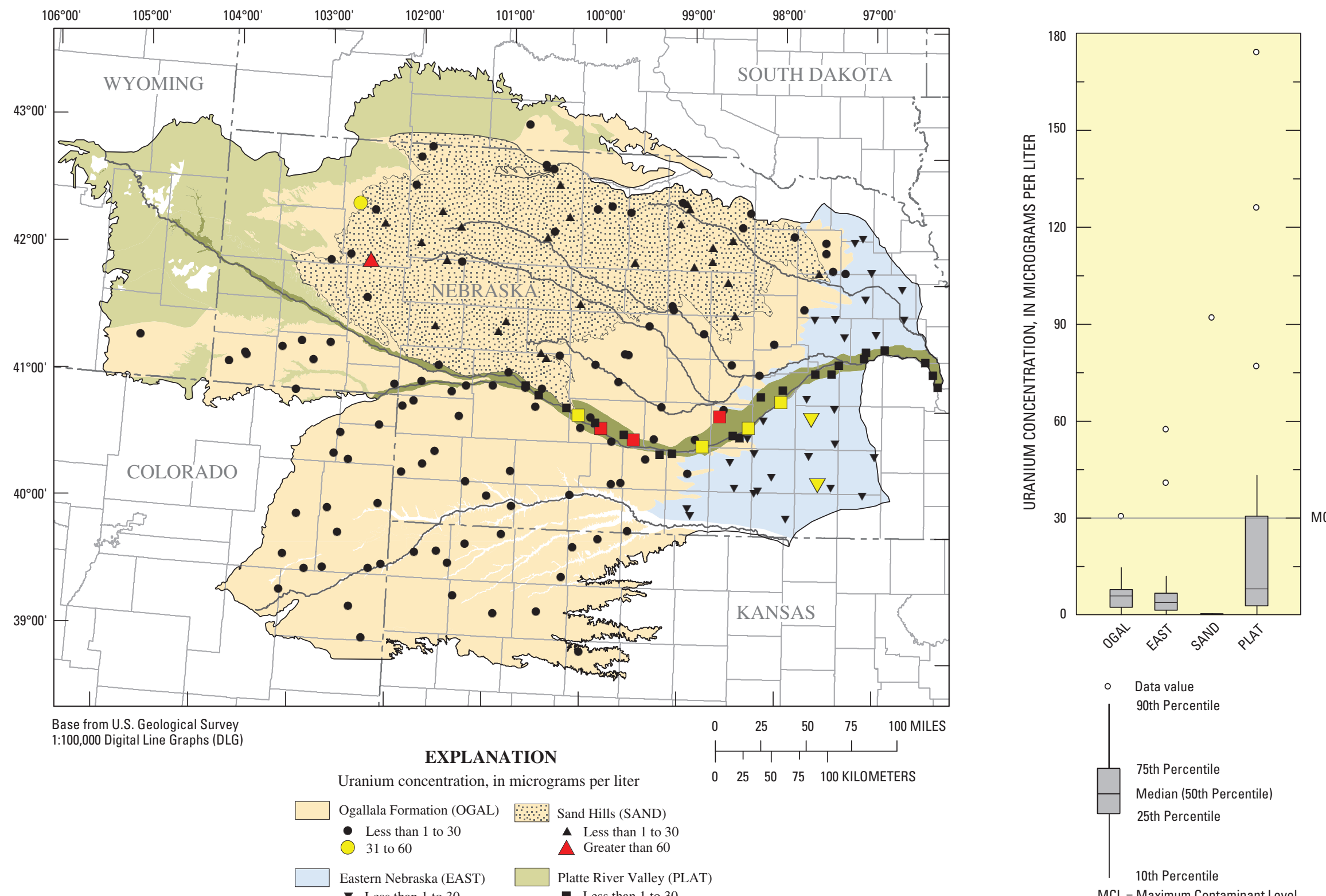

Figure 15. Distribution of uranium concentrations by hydrogeologic unit in the northern High Plains aquifer, 1997, $2002-04$. 
(U.S. Department of the Interior, 1998). Selenium concentrations varied among the hydrogeologic units. The highest median selenium concentration $(5.9 \mu \mathrm{g} / \mathrm{L})$ was in the EAST unit, and the lowest median $(<1 \mu \mathrm{g} / \mathrm{L})$ was in the SAND unit (table 9). The EAST unit also had the highest overall selenium concentration $(71.3 \mu \mathrm{g} / \mathrm{L})$ in a single sample as well as the greatest percentage of samples that exceeded the USEPA MCL (7 percent).

Trace elements that exceeded a nonenforceable USEPA drinking-water standard (SDWR or LTHA) in the 192 samples collected in the northern High Plains were aluminum ( $<1$ percent), boron $(<1$ percent $)$, iron ( 6 percent), manganese (6 percent), and molybdenum ( $<1$ percent). Trace elements that were detected but did not have or did not exceed either an enforceable or unenforceable USEPA drinking-water standard were antimony, barium, cadmium, chromium, cobalt, copper, lead, lithium, nickel, strontium, thallium, vanadium, and zinc. Trace elements that were analyzed but not detected were beryllium and silver. Aluminum and copper concentrations were detected in blank samples near environmental sample concentrations; therefore, concentrations of these constituents in samples might be artificially higher than actual groundwater conditions.

\section{Dissolved Organic Carbon}

Sources of DOC are numerous and can include the decay of organic materials in the soil, landfill leachate, petroleum products, animal waste, and the aquifer sediments. As previously mentioned, organic carbon is influential in redox conditions. DOC concentrations were relatively low in the northern High Plains, ranging from $<0.3$ to $3.9 \mathrm{mg} / \mathrm{L}$, with the exception of one sample. Water from NSS-204 had a DOC concentration of $25.5 \mathrm{mg} / \mathrm{L}$. This water sample was collected from a shallow domestic well in the small town of Lakeside, Nebraska. The sample also had relatively large concentrations of dissolved solids, ions, and trace elements compared to other samples collected in the northern High Plains. No point sources of DOC were observed; however, likely sources might be private septic systems or nearby shallow lakes. Lakes in the Sand Hills are organically productive. Nash (1978) measured DOC in 14 lakes in Sheridan County and reported concentrations ranging from 139 to $572 \mathrm{mg} / \mathrm{L}$. As discussed previously, the water chemistry from NSS-204 indicates evaporative processes have concentrated dissolved solids. Therefore, the source of elevated DOC in water from this well probably is decayed organic matter from the nearby shallow lakes that has moved into shallow ground water. Water collected from a deeper well (NOS-1082) located less than $800 \mathrm{ft}$ away from NSS-204 had a much smaller DOC concentration $(0.6 \mathrm{mg} / \mathrm{L})$.

DOC concentrations varied among the units. The median DOC concentration was smallest in the OGAL $(0.3 \mathrm{mg} / \mathrm{L})$; the SAND $(0.5 \mathrm{mg} / \mathrm{L})$ and EAST $(0.7 \mathrm{mg} / \mathrm{L})$ units had slightly larger median concentrations (table 9 ). The median DOC con- centration was not calculated in the PLAT because DOC was detected in all of the field blanks from that unit at concentrations at or near environmental sample concentrations. Concentrations were significantly different among the other three units (p-values $<0.10$ )

\section{Radon}

Radon is a radioactive gas that occurs naturally in the environment when uranium in soil, rock, or water decays. The source of radon in wells is rock material immediately surrounding the well because the velocity of ground-water flow and the relatively short half-life (3.8 days) of radon (Hem, 1985) limit the distance that radon can travel before it decays. Although radon is a degradate of uranium, concentrations of uranium and radon did not significantly correlate. This relation is expected because uranium and radon have different chemical properties and decay half-lives.

Breathing radon is the second leading cause of lung cancer in the United States and therefore is a serious health risk (U.S. Environmental Protection Agency, 2003). The USEPA estimates that radon from indoor air causes about 21,000 cancer deaths per year, and radon from drinking water causes about 168 cancer deaths per year. Radon in soil under homes is the primary source in indoor air. Tapwater only contributes about 1 to 2 percent of radon in indoor air but still poses a health risk to humans who are exposed over long periods of time. The health risks associated with radon in drinking water occur when the water is ingested or when radon escapes from the water and is inhaled. An MCL of $300 \mathrm{pCi} / \mathrm{L}$ for radon in drinking water has been proposed but has not yet been approved (U.S. Environmental Protection Agency, 2004).

Radon concentrations in the northern High Plains ranged from 100 to $1,640 \mathrm{pCi} / \mathrm{L}$, with a median of $290 \mathrm{pCi} / \mathrm{L}$. Eighty-seven of the 187 samples (47 percent) analyzed had a radon concentration higher than the proposed USEPA MCL of $300 \mathrm{pCi} / \mathrm{L}$. Water samples collected from the OGAL had the highest median radon concentration $(320 \mathrm{pCi} / \mathrm{L})$ (table 9$)$. The five highest radon concentrations were also from water samples collected from the OGAL. The SAND unit had the lowest median radon concentration ( $230 \mathrm{pCi} / \mathrm{L})$. Radon concentrations were significantly smaller in the SAND than the other three units ( $\mathrm{p}$-values $<0.10$ ), but differences between the other units were not statistically significant.

\section{Volatile Organic Compounds}

VOCs are a group of carbon-based, generally synthetic compounds with properties that allow them to readily change from a solid or liquid to a gas. Many VOCs are toxic. Health concerns include cancer; liver, kidney, lung, circulation, nervous- and respiratory-system effects; eye, skin, and throat irritation; mental confusion; and damage to blood cells (U.S. Environmental Protection Agency, 1994, 1996). 
VOCs are used for many purposes and are present in common products such as solvents, paints, glues, petroleum products, and household cleaners. VOCs can be grouped into seven categories: fumigants, gasoline hydrocarbons, compounds used in organic synthesis, oxygenates, refrigerants, solvents, and trihalomethanes (Moran and others, 2002). The first six categories are commonly used in households and are potential point-source contaminants to domestic wells. VOCs in the seventh category, trihalomethanes, are typically generated as a byproduct of water disinfection and are created when chlorinated compounds react with organic matter. Shock chlorination of domestic wells is a common practice in the study area and can provide a source of trihalomethanes.

The NAWQA Program chose 86 VOCs to be analyzed. They were chosen with consideration to physical properties, potential risk to human health, toxicity to aquatic organisms, frequency of detection in ground water, surface water, or drinking water, and importance for other reasons such as bioaccumulation in aquatic organisms or atmospheric ozone depletion (Bender and others, 1999). General information about VOCs that were analyzed for in this study is in Appendix 3. Figure 16 shows all VOC concentrations above and below the highest LRL. For purposes of this report, a VOC concentration was only identified as a detection if the concentration was at or above the highest LRL. Nine VOCs were detected in the northern High Plains. Locations of water samples with VOC detections are shown in figure 17. Sixteen wells in the study area had one or more VOCs detected. All VOC concentrations were below the highest concentration allowed by USEPA drinking-water standards. The most commonly detected VOCs were trihalomethanes and solvents.

The PLAT had the highest percentage of VOC detections. Twenty-two percent of wells sampled in the PLAT unit produced water that had at least one detectable VOC-11 percent of sites in that unit had detectable trichloromethane (chloroform), 11 percent had detectable tetrahydrofuran, and 4 percent had detectable dichlorodifluoromethane (CFC12). Water from wells completed in the OGAL had more types of VOCs detected but at lower frequencies: trichloromethane (4 percent), bromodichloromethane (1 percent), tribromomethane (1 percent), 1,2-dichlorobenzene (1 percent), and tetrachloromethane ( 1 percent). Two VOCs were detected in the EAST unit-1,2,4-trimethylbenzene (7 percent) and 1,2-dichloroethane (3 percent). 1,2-dichloroethane was detected at 4 percent of the wells in the SAND. Concentrations of tetrahydrofuran and 1,2,4-trimethylbenzene in blank samples were near environmental sample concentrations; therefore, reported concentrations of these constituents may be higher than actual aquifer conditions.

\section{Tritium}

Isotopes, forms of an element with the same number of protons but differing numbers of neutrons, can help determine the sources, residence time, quality, chemical evolution, and recharge processes of ground water. Tritium is an isotope of hydrogen that is used to estimate the relative residence time of water in an aquifer. Though tritium is produced naturally in the upper atmosphere when cosmic rays interact with air molecules, it is also a byproduct of nuclear weapons explosions. Bomb testing in the 1950 s and 1960 s caused tritium in the atmosphere to increase many times above natural levels. As a result, tritium in precipitation and thus, in recharge water, also increased substantially. In 1963, the United States and the Soviet Union banned atmospheric nuclear bomb testing; consequently, the input of tritium into the atmosphere dropped off to near background levels. Since then, tritium levels have gradually decreased by radioactive decay (half-life $=12.43$ years, Unterweger and others, 1980). Once water has entered an aquifer or is otherwise no longer in contact with the atmospheric tritium source, tritium levels will gradually decrease by radioactive decay. Bomb-released tritium that entered ground water during the 1950s and 1960s provided such a substantial initial input that radioactive decay has not entirely depleted it by the time samples were collected for this study. Ground water that was affected by bomb-released tritium will still have more than about $1.5 \mathrm{pCi} / \mathrm{L}$ tritium (Thatcher, 1962; Clark and Fritz, 1997). Water pumped from wells is typically a mixture of ground waters of different age over the length of the screen. The occurrence of tritium in a groundwater sample at concentrations greater than $1.5 \mathrm{pCi} / \mathrm{L}$ is an indication that at least some portion of the water sample was recharged after about 1960; the entire sample does not necessarily, and generally does not, have a residence time of less than 50 years.

Tritium concentrations were analyzed at 121 of the 192 wells. All of the sites in the PLAT were analyzed for tritium. In the other units, tritium typically was analyzed for only if there was no other evidence that water had been recently recharged. A detection of either a pesticide or VOC and(or) a nitrate concentration above $4 \mathrm{mg} / \mathrm{L}$ provided evidence of recent recharge. In a few cases, financial constraints prevented analyzing for tritium when there was no evidence of recent recharge.

Fifty-two of the 121 wells analyzed had detectable tritium. Concentrations ranged from less than 1 to $113 \mathrm{pCi} / \mathrm{L}$, with a median of less than $1 \mathrm{pCi} / \mathrm{L}$. The tritium concentration in 48 samples was higher than $1.5 \mathrm{pCi} / \mathrm{L}$, indicating that some portion of the water in those samples had been recently recharged. The median tritium concentration in samples collected from the PLAT (37 pCi/L) was much higher than in the other units (ranging from $<1$ to $1 \mathrm{pCi} / \mathrm{L}$ ). However, comparing relative concentrations between the PLAT unit and the other units is misleading because tritium in the OGAL, EAST, and SAND units was analyzed only at sites showing no other evidence of young water. The process of selecting sites to be analyzed for tritium in those units eliminated many sites that might have had high tritium concentrations. 

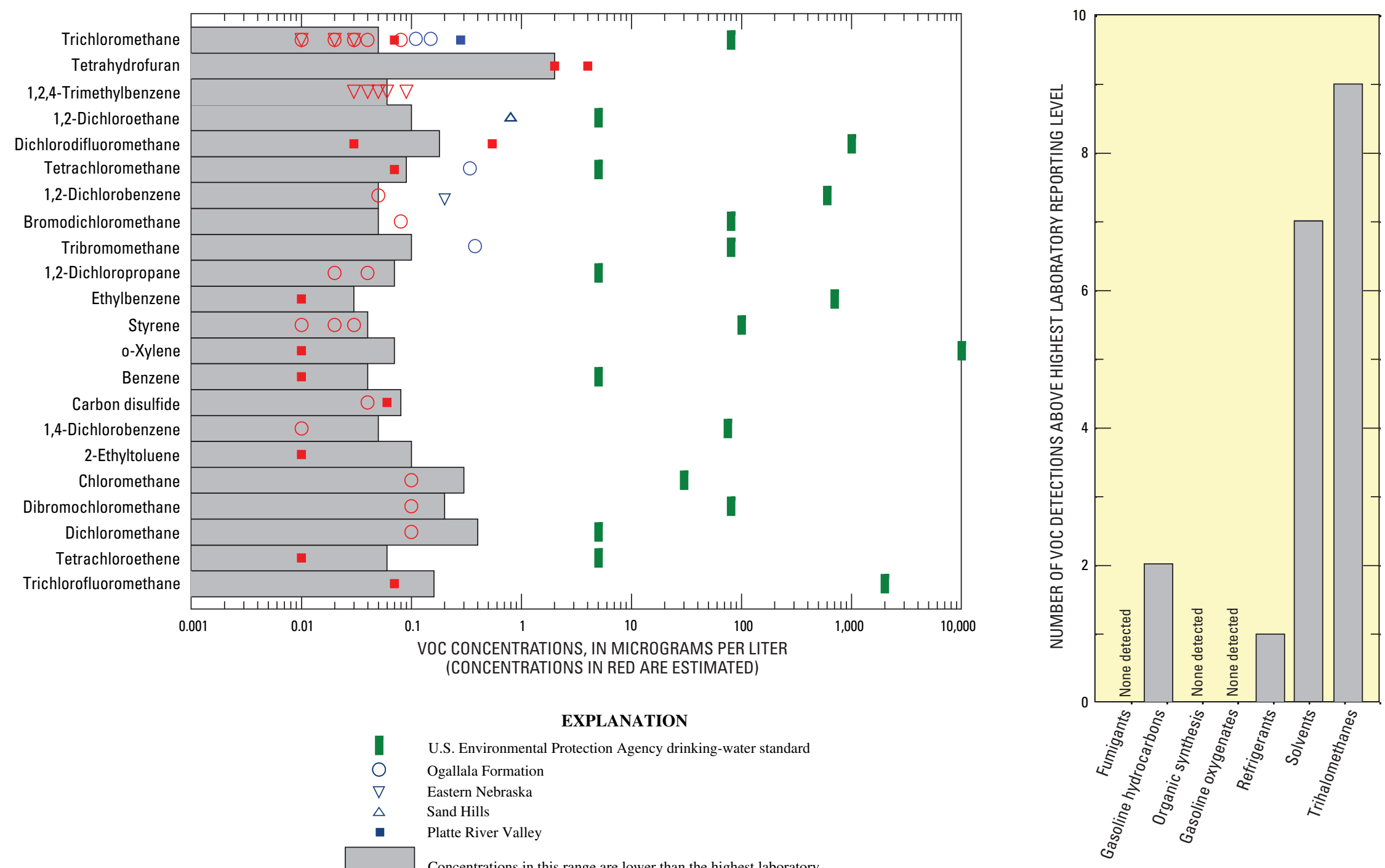

\section{EXPLANATION}

\begin{tabular}{ll}
\hline & U.S. Environmental Protection Agency drinking-water standard \\
$\nabla$ & Ogallala Formation \\
$\Delta$ & Eastern Nebraska \\
$\Delta$ & Sand Hills \\
$\square$ & Platte River Valley \\
& $\begin{array}{l}\text { Concentrations in this range are lower than the highest laboratory } \\
\text { reporting level }\end{array}$
\end{tabular}

Figure 16. Volatile organic compound (VOC) concentrations in the northern High Plains aquifer, 1997, 2002-04. 

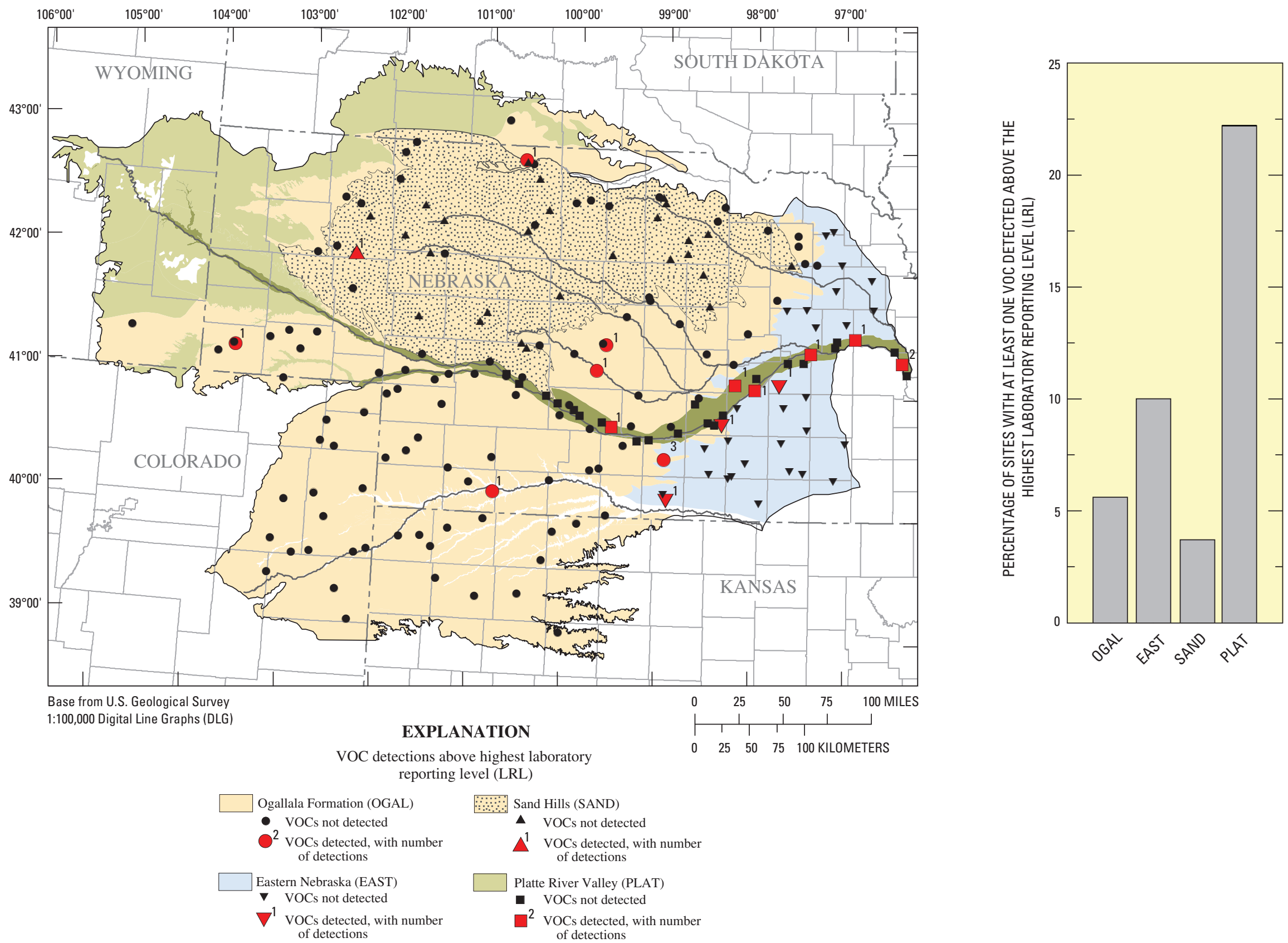

Figure 17. Distribution of volatile organic compound (VOC) detections by hydrogeologic unit in the northern High Plains aquifer, 1997, $2002-04$. 
The amount of time that water has resided as ground water (not in contact with the atmosphere) can have meaningful implications for ground-water quality. Widespread irrigation and application of agricultural chemicals have only been in practice in the northern High Plains for about 50 years (Kuzelka and Flowerday, 1993). Therefore, ground water that entered the saturated zone less than 50 years ago has a higher potential to be affected by agricultural activities than older water. Some ground water in the northern High Plains aquifer has been dated using carbon-14 to be as much as 12,000 years old (Peter McMahon, U.S. Geological Survey, written commun., 2005). It should be expected that human activities have not affected ground-water quality in these waters. However, older ground water is typically considered to be more likely to have higher dissolved-solids concentrations, including some potentially harmful minerals and elements such as fluoride, arsenic, and uranium.

Concentrations of nitrate, pesticides, VOCs, and tritium were used to determine the relative age of the ground-water samples. Of the 192 samples collected, 85 were classified as containing some fraction of water younger than 50 years by nitrate greater than $4 \mathrm{mg} / \mathrm{L}$, the presence of one or more pesticide compounds, one or more VOCs, or tritium greater than $1.5 \mathrm{pCi} / \mathrm{L}$. Water from 99 wells was considered to be older than 50 years as indicated by nitrate less than $4 \mathrm{mg} / \mathrm{L}$ with oxic water, no detectable pesticide compounds or VOCs, and tritium less than $1.5 \mathrm{pCi} / \mathrm{L}$ (or not analyzed). Water from eight wells could not be classified. These wells had nitrate concentrations less than $4 \mathrm{mg} / \mathrm{L}$ with post-oxic or sulfidic water, had no detectable pesticides or VOCs, and were not analyzed for tritium.

As is typically determined, samples containing water less than 50 years old were present at shallower depths than samples with water more than 50 years old. The depth of the middle of the well screen below the water table was compared for samples with young and old water. Samples containing water younger than 50 years had a median depth below water table of $52.50 \mathrm{ft}$, and water samples having water older than 50 years had a median depth below water table of $104.66 \mathrm{ft}$ $(\mathrm{p}=<0.001)$. Young water indicators (nitrate, pesticide compounds, VOCs, and tritium) are shown relative to depth below the water table in figure 18. In general, elevated nitrate, pesticide compound detections, VOC detections, and elevated tritium are present near the water table.

The geographic distribution of samples with water less than 50 years old, water more than 50 years old, and water with unknown age is shown in figure 19. Water from samples collected in the PLAT unit was recharged within the last 50 years more frequently than water samples from the other units. Eighty-nine percent of samples in the PLAT unit, 57 percent of samples in the EAST unit, 52 percent of samples in the SAND unit, and 28 percent of samples in the OGAL unit contained water less than 50 years old. Fifty-six (66 percent) of the samples containing young water were affected by agricultural activities as indicated by the presence of at least one detected pesticide compound and nitrate larger than $4 \mathrm{mg} / \mathrm{L}$.

\section{Microbiology}

Total coliforms and $E$. coli are two indicator bacteria that, although not harmful themselves, indicate the likely presence of waterborne disease-causing organisms. Coliforms are naturally present in the environment, including feces. Total coliforms is a measure of all bacteria species of the coliform group. E. coli is a type of coliform bacteria that is only present in animal and human fecal waste. Therefore, E. coli is the preferred indicator of fecal contamination (U.S. Environmental Protection Agency, 2004). The NAWQA Program began regularly analyzing indicator bacteria in ground water in 2003. Total coliforms and E. coli were collected and analyzed by the sampling teams in the study area only in the units that were sampled since then-the SAND and EAST units. Thirty samples were collected in the EAST unit; however, one sample was ruined and therefore indicator bacteria were not counted for that sample. E. coli was not detected in any of the samples, and total coliforms were detected in six samples. The maximum total coliforms count was 15 colonies per 100 milliliters. In the SAND unit, one sample was ruined and indicator bacteria are only available for 26 samples. Twenty-four wells in the SAND unit had no detections of indicator bacteria, one sample had 18 colonies per 100 milliliters of total coliforms and E. coli, and one sample had one colony per 100 milliliters of total coliforms and E. coli. The USEPA has set the MCLG for $E$. coli to 0 colonies per 100 milliliters. Of the 55 indicator bacteria samples analyzed, two samples (4 percent) exceeded the USEPA MCLG for E. coli. Multiple samples are required to determine whether the USEPA MCLG for total coliforms is exceeded. Therefore, it could not be determined using results from a single sampling event whether total coliforms exceeded the USEPA standard.

Samples analyzed for bacteria also were analyzed for coliphages. Coliphages are viruses that infect and replicate in fecal bacteria. Although they are not pathogenic to humans, they have similar structure, transport, and persistence in the environment as the enteric viruses that are pathogenic to humans. For these reasons, they are used to predict the likely presence of enteric viruses. The two main groups of coliphages are somatic and F-specific. Raw sewage typically contains somatic and F-specific coliphage concentrations of 1,000 plaque-forming units per milliliter (Bushon, 2003). Neither coliphage was detected in water samples.

\section{Relation Between Hydrogeologic and Land-Use Variables and Ground-Water Quality}

The four units have unique hydrogeologic properties that influence ground-water chemistry and the transport of anthropogenic chemicals to ground water. Land-use practices also differ among the four units and can affect ground-water chemistry. Important differences among the units include 


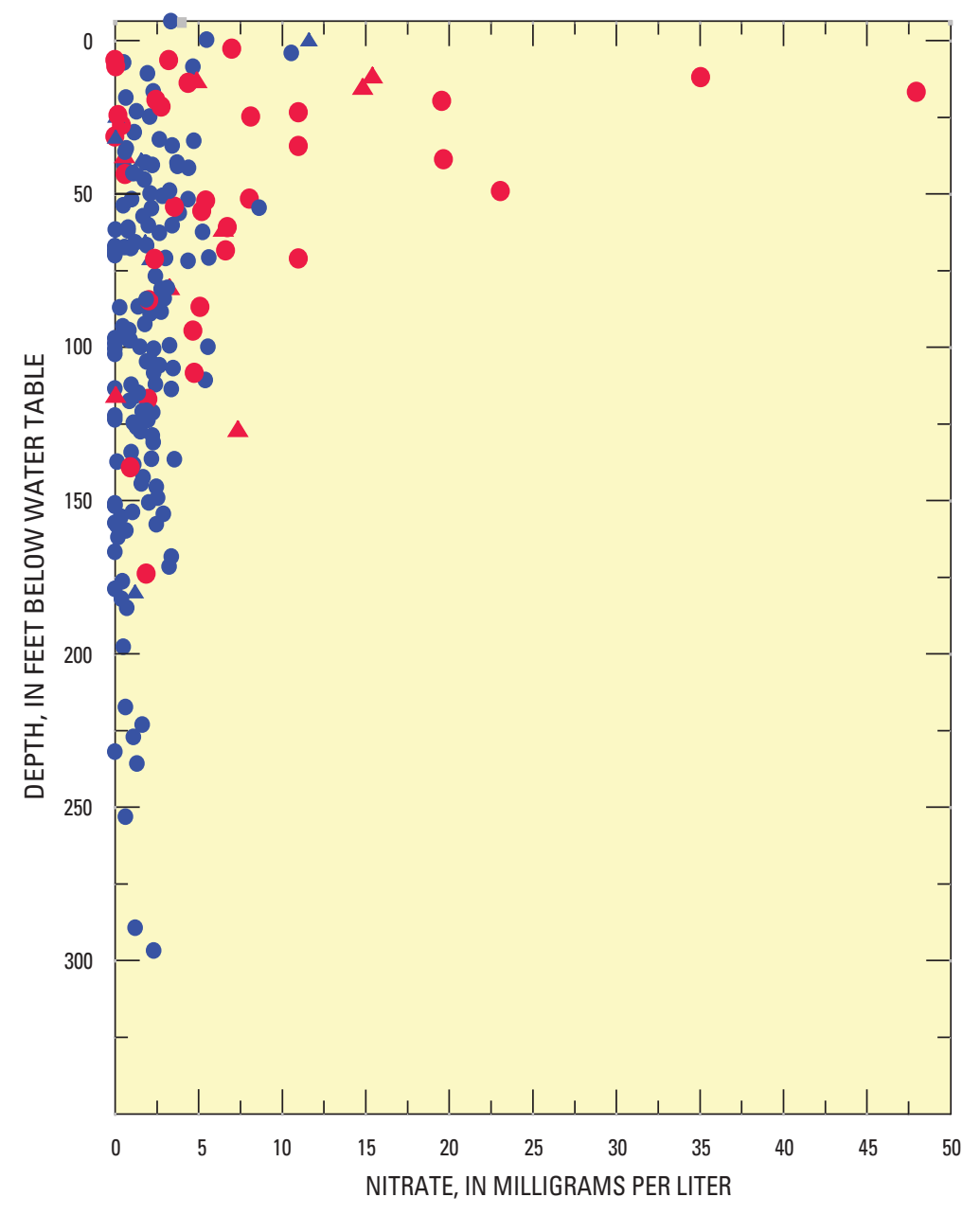

\section{EXPLANATION}

Nitrate concentration, in milligrams per liter

- Pesticide compounds and VOCs not detected

- Pesticide compounds not detected; at least one VOC detected

- At least one pesticide compound detected; VOCs not detected

- At least one pesticide compound detected and at least one VOC detected

Figure 18. Distribution of nitrate concentrations, pesticide detections, volatile organic compound (VOC) detections, and tritium concentrations relative to depth below the water table in the northern High Plains aquifer, 1997, 2002-04.

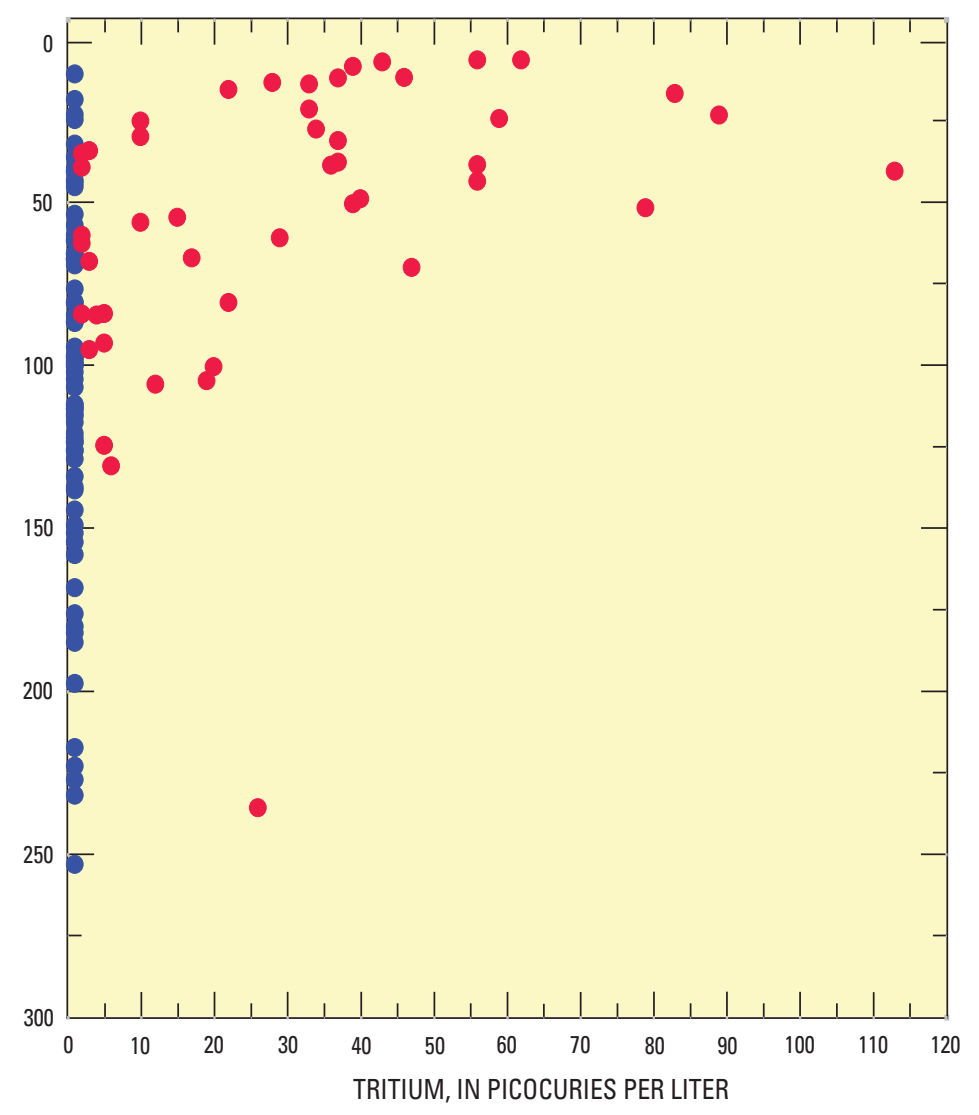

\section{EXPLANATION}

Tritium concentration, in picocuries per liter

- Contains water recharged in the last 50 years

Water recharged more than 50 years ago 

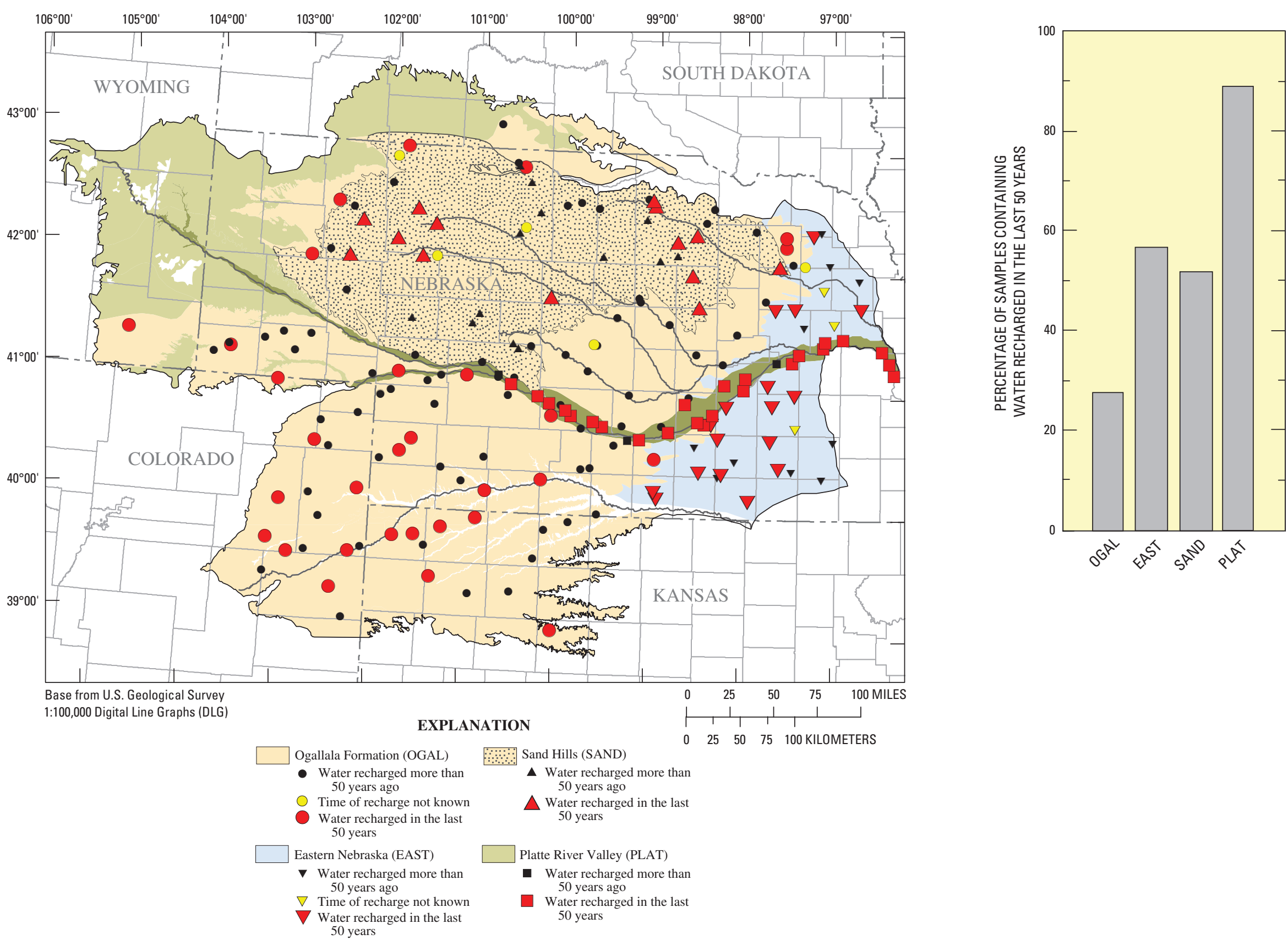

Figure 19. Distribution of samples containing water recharged in the last 50 years by hydrogeologic unit in the northern High Plains aquifer, 1997, $2002-04$. 
depth to water, depth of the well screen below the water table, redox conditions, ground-water residence time, interactions with surface water, composition of aquifer sediments, extent of cropland, extent of irrigated land, and fertilizer application rates.

Few anthropogenic compounds were detected in water from the OGAL unit. Of the samples collected in the OGAL, 3 percent exceeded the nitrate MCL, 8 percent had at least one pesticide compound detected, 6 percent had at least one VOC detected, 4 percent exceeded the dissolved-solids SDWR, and 1 percent exceeded the sulfate SDWR. Large depths to water and relatively lower percentages of land use dedicated to cropland and irrigated cropland may explain the relatively low number of anthropogenic compounds detected in ground water. Wells sampled in the OGAL unit had the second largest median depth to water $(77 \mathrm{ft})$ below land surface and the largest median depth of well screens (100 ft below the water table) (table 7). Forty-six percent of the land overlying this unit was cropland and 10 percent was irrigated cropland (table 1)-smaller percentages than the PLAT and the EAST units. The median dissolved-oxygen concentration was largest in the OGAL unit, and only 16 percent of samples had post-oxic water; therefore, denitrification would probably not explain the smaller nitrate concentrations in the unit. Several constituents found in the OGAL but not typically associated with human activities exceeded drinking-water standards - the arsenic MCL was exceeded in 6 percent of samples, the iron SDWR was exceeded in 1 percent of samples, the manganese LTHA was exceeded in 2 percent of samples, the uranium MCL was exceeded in 1 percent of samples, and the proposed radon MCL was exceeded in 54 percent of samples.

The EAST unit has some characteristics that can reduce aquifer vulnerability, or risk, to contamination from anthropogenic compounds and some characteristics that enhance vulnerability to contamination. A relatively thick layer of loess overlies much of this unit to inhibit downward flow of water and contaminants. Wells sampled in the EAST unit had the largest median depth to water $(89.58 \mathrm{ft}$ below land surface; table 7). Wells also withdrew water from relatively deep in the unit. The median depth of well-screen midpoints was $82.91 \mathrm{ft}$ below the water table. Other factors offset the hydrogeologic characteristics that limit movement of chemicals to ground water. Eighty-three percent of the overlying land is dedicated to cropland (table 2) and 34 percent is irrigated cropland, indicating that agricultural chemicals are likely to be applied over a large portion of the unit. Nitrogen and pesticide application rates were similar to the PLAT unit. This unit is also in the wettest part of the northern High Plains and, therefore, recharge rates are larger (Dugan and Zelt, 2000). Larger recharge rates coupled with the heavy irrigation over this unit may be more likely to move chemicals from the land surface to ground water. Also, irrigation withdrawals may pull young water down to the aquifer faster than would otherwise occur. This unit had the second largest percentage of samples (57 percent) with at least one indicator of young water, indicating that ground water may likely be affected by recent human activities. Thirty percent of water samples in this unit exceeded the dissolved-solids SDWR, 7 percent exceeded the sulfate SDWR, 23 percent had at least one detectable pesticide compound, and 10 percent had at least one detectable VOC. However, the median nitrate concentration in the EAST unit $(1.92 \mathrm{mg} / \mathrm{L})$ was lower than either the PLAT or the OGAL unit, and the drinking-water standard for nitrate was not exceeded in any water sample. The relatively low nitrate concentrations might be related to denitrification. Eleven samples (37 percent) had dissolved-oxygen concentrations less than $1 \mathrm{mg} / \mathrm{L}$, conditions favorable for denitrification. Concentrations of several constituents generally associated with geologic sediments exceeded drinking-water standards. Ten percent of samples exceeded the arsenic MCL, 23 percent exceeded the iron SDWR, 13 percent exceeded the manganese LTHA, selenium and uranium concentrations exceeded their respective MCL in 7 percent of the samples, 3 percent exceeded the boron LTHA, and 45 percent exceeded the proposed radon MCL.

The SAND unit shared similar hydrogeologic properties with the PLAT unit - shallow depths to water and porous soils and aquifer sediments. However, anthropogenic compounds such as elevated nitrate, pesticides, and VOCs were frequently not detected-4 percent of samples exceeded the nitrate MCL, 15 percent of samples had at least one pesticide detected, 4 percent had at least one VOC detected, 4 percent exceeded the dissolved-solids SDWR, and no samples exceeded the sulfate SDWR. Although this unit is susceptible to contamination, the absence of anthropogenic compounds can be attributed to the nonintensive land use of the area-mainly rangeland (table 2). Because cropland accounted for only a small portion of the land use overlying the SAND unit, nitrogen and pesticide application rates were smallest over this unit. Other constituents exceeded drinking-water standards-15 percent exceeded the arsenic MCL, 4 percent exceeded the aluminum SDWR, 4 percent exceeded the iron SDWR, 4 percent exceeded the uranium MCL, and 23 percent exceeded the proposed radon MCL. One shallow well in the SAND unit (NSS-204) had anomalously high concentrations of many major ions, trace elements, and DOC and accounts for several of the drinking-water exceedances. This well is in an area where evaporative processes probably have concentrated these constituents in "closed-basin" lakes.

The PLAT unit has hydrogeologic and land-use characteristics associated with an increased risk of ground-water contamination relative to the other units-shallow depth to ground water, permeable soils and aquifer sediments, dense population, short ground-water residence times (young water), intensively cropped agricultural lands, and relatively large nitrogen and pesticide application rates. Wells sampled in this unit drew water from shallower depths in the aquifer where influence from activities at the land surface is typically more pronounced. Additionally, in many areas, regional ground-water flow paths converge on the PLAT unit, which 
could result in higher dissolved solids. When this condition is coupled with intense irrigation, evaporative concentration may further increase dissolved solids in soils and ground water. In the PLAT unit, 31 percent of the water samples exceeded the nitrate MCL, 78 percent of samples had at least one pesticide compound detected, 18 percent of samples had at least one VOC detected, 38 percent exceeded the dissolved-solids SDWR, and 19 percent exceeded the SDWR for sulfate. Fiftynine percent of the wells sampled in this unit were post-oxic, indicating that conditions are favorable for denitrification. Nitrate concentrations in this unit might be larger if water were primarily oxic. Constituents not generally associated with anthropogenic activities also exceeded drinking-water standards -26 percent exceeded the uranium MCL, 22 percent exceeded the manganese LTHA, 11 percent exceeded the arsenic MCL, 7 percent exceeded the iron SDWR, 4 percent exceeded the molybdenum LTHA, and 41 percent exceeded the proposed radon MCL.

\section{Summary}

An assessment of ground-water quality in the northern High Plains aquifer was completed during 1997 and 2002-04. Ground-water samples were collected at 192 low-capacity wells in four of the five major hydrogeologic units of the northern High Plains aquifer. Each well was sampled once, and water at all sites was analyzed for physical properties and concentrations of nitrogen and phosphorus compounds, pesticides and pesticide degradates, dissolved solids, major ions, trace elements, DOC, radon, and VOCs. Measurements made at the time of sample collection were turbidity, dissolved oxygen, $\mathrm{pH}$, water temperature, specific conductance, carbonate alkalinity, and depth to water. Hydrogen sulfide was measured at sites with dissolved oxygen less than $1 \mathrm{mg} / \mathrm{L}$. Microbiology and tritium were analyzed at selected sites. The results of this assessment were compared to national public-supply drinkingwater standards to determine the relative quality of private water supplies. Results were related to natural and human factors in an attempt to understand the processes that control the occurrence and concentrations of selected constituents in ground water.

Nitrate concentrations exceeded the MCL in water from 6 percent of samples. Nineteen percent of samples had nitrate concentrations higher than $4 \mathrm{mg} / \mathrm{L}$, indicating that some parts of the aquifer have been affected by human activities. Ammonia, nitrite, ammonia plus organic nitrogen, and orthophosphate were measured at relatively low concentrations in the aquifer. Because the majority of water samples were oxic, the principal form of nitrogen in the northern High Plains aquifer was nitrate, and denitrification is not likely to lower nitrate concentrations in most parts of the aquifer. However, dissolved-oxygen concentrations were less than $1 \mathrm{mg} / \mathrm{L}$ in 26 percent of the samples and samples with these redox conditions could facilitate denitrification.
Nine pesticides and two pesticide degradates were detected in the northern High Plains aquifer with concentrations well below their respective maximum concentration allowed in drinking water. Atrazine and deethylatrazine were detected most frequently. Detected atrazine concentrations ranged from 0.007 to $0.691 \mu \mathrm{g} / \mathrm{L}$, and deethylatrazine was detected at estimated concentrations ranging 0.006 to $0.802 \mu \mathrm{g} / \mathrm{L}$. Other pesticide compounds detected were simazine, metolachlor, prometon, 2-hydroxyatrazine, diuron, tebuthiuron, 2,4-D methyl ester, bentazon, and diazinon. Most of the pesticide detections were in water samples collected from the PLAT unit. The number of pesticide detections in a sample was negatively correlated with depth to the water table and the depth of well-screen midpoints below the water table. The number of pesticide detections was positively correlated with nitrate, dissolved solids, sulfate, and chloride concentrations.

The median dissolved-solids concentration was $290 \mathrm{mg} / \mathrm{L}$. Twenty-four samples (13 percent) exceeded the USEPA SDWR. Nineteen of those 24 samples that violated the SDWR were in the EAST or PLAT units. Dissolved-solids concentrations decreased as the depth that a sample was collected below the water table increased. Dissolved-solids concentrations were positively correlated with nitrate and chloride concentrations. Dissolved-solids concentrations were significantly larger in samples with an elevated nitrate concentration and(or) where at least one pesticide detected.

The dominant cation was calcium, and the dominant anion was most commonly carbonate alkalinity. In a few samples collected in the PLAT unit or near the Platte River, the dominant anion was sulfate. Major-ion compositions in samples collected near the Platte River indicate that ground water may contain a component of surface water. Four percent of water samples collected in the northern High Plains exceeded the USEPA SDWR of $250 \mathrm{mg} / \mathrm{L}$ for sulfate concentrations. Most of the samples that exceeded the sulfate SDWR were in the PLAT unit.

Arsenic, uranium, and selenium were the only trace elements that exceeded USEPA enforceable drinking-water standards in the northern High Plains. Trace elements that exceeded a nonenforceable USEPA drinking-water standard were aluminum, boron, iron, manganese, and molybdenum. Trace elements that were present but did not have or did not exceed either an enforceable or nonenforceable USEPA drinking-water standard were antimony, barium, cadmium, chromium, cobalt, copper, lead, lithium, nickel, strontium, thallium, vanadium, and zinc.

Eight percent of the samples collected exceeded the USEPA MCL for arsenic. Arsenic was positively correlated with vanadium and molybdenum, indicating that the sources of arsenic in the northern High Plains are probably natural. Arsenic concentrations also were positively correlated with $\mathrm{pH}$. In the EAST unit, arsenic was positively correlated with iron in post-oxic waters, indicating that dissolution of iron oxide is a source of arsenic in parts of that unit. 
Six percent of the water samples had uranium concentrations greater than the USEPA MCL for uranium. The median uranium concentration was highest in the PLAT. Water collected from the PLAT also had a higher percentage of MCL exceedances and the highest overall uranium concentration. The SAND unit had the lowest uranium concentrations. Uranium was positively correlated with concentrations of dissolved solids, chloride, and almost all other major ions, indicating that evaporative processes may affect uranium concentrations in ground water. Uranium concentrations also were significantly higher in samples screened within 50 feet of underlying Cretaceous (marine shale) bedrock.

Forty-seven percent of samples exceeded the proposed USEPA MCL of $300 \mathrm{pCi} / \mathrm{L}$ for radon. Water samples collected from the OGAL had the highest median radon concentration and the five highest radon concentrations. The SAND had the lowest median radon concentration.

Nine VOCs were detected in the northern High Plains. Sixteen wells (17 percent) in the study area had one or more VOCs detected. All VOC concentrations were below the highest concentration allowed by USEPA drinking-water standards. The most commonly detected VOCs were trihalomethanes and solvents. The PLAT had the highest percentage of wells with at least one VOC detected.

Fifty-two of the 121 wells analyzed had detectable tritium ranging from 1 to $113 \mathrm{pCi} / \mathrm{L}$. The tritium concentration in 48 samples was higher than $1.5 \mathrm{pCi} / \mathrm{L}$, indicating that some portion of the water in those samples had been recharged during the last 50 years.

Concentrations of nitrate, pesticides, VOCs, and tritium were used to determine the relative age of the ground-water samples. Forty-four percent of the samples were classified as containing some fraction of water younger than 50 years. Eighty-nine percent of samples in the PLAT unit, 57 percent of samples in EAST unit, 52 percent of samples in the SAND unit, and 28 percent of sites in the OGAL unit contained water less than 50 years old. Sixty-six percent of the samples with young water were affected by agricultural activities as indicated by the presence of at least one detectable pesticide and nitrate concentration larger than $4 \mathrm{mg} / \mathrm{L}$. Water less than 50 years old was present at shallower depths than water more than 50 years old.

Total coliforms, E. coli, and viral coliphages were collected and analyzed in the EAST and SAND units. In the EAST, E. coli was not detected in any of the wells and total coliforms were detected in six wells. The maximum total coliforms count was 15 colonies per 100 milliliters. In the SAND, one well had 18 colonies per 100 milliliters of total coliforms and E. coli, and one well had one colony per 100 milliliters of total coliforms and E. coli. Viral coliphages were not detected in water samples.

Hydrogeologic and land-use characteristics affected ground-water chemistry. Hydrogeologic and land-use factors in the OGAL are associated with a decreased risk of contamination by human activities. As a result, few anthropogenic compounds were detected in samples collected from that unit. The EAST unit has some hydrogeologic and land-use characteristics associated with an increased risk to contamination; other hydrogeologic factors may be limiting the movement of chemicals to ground water. This unit had the second largest number of pesticide and VOC detections and dissolved-solids concentrations. However, the median nitrate concentration was lower than either the PLAT or the OGAL unit. The SAND unit had hydrogeologic properties favorable for movement of chemicals to the ground water, but the land use is primarily rangeland. Anthropogenic compounds such as elevated nitrate, pesticides, and VOCs were generally not detected. The hydrogeologic and land-use setting in the PLAT is generally associated with an increased potential to be affected by human activities. Samples collected in the PLAT unit more often exceeded drinking-water standards for many constituents and had more samples with pesticide and VOC detections than the other units.

\section{References Cited}

American Public Health Association, 1998, Standard methods for the examination of water and wastewater (20th ed.): Washington, D.C., American Public Health Association, American Water Works Association, and Water Environment Federation, p. 3-37-3-43.

American Society for Testing and Materials, 1996, Annual environmental technology: American Society for Testing and Materials, v. 11.02, D-5072-92, p. 674-676.

Augustijn-Beckers, P.W.M., Hornsby, A.G., and Wauchope, R.D., 1994, The SCS/ARS/CES pesticide properties database for environmental decision making II, Additional compounds: Reviews of Environmental Contamination and Toxicology, v. 137, p. 1-82.

Barbash, J.E., and Resek, E.A., 1996, Pesticides in ground water-Distribution, trends, and governing factors: Chelsea, Mich., Ann Arbor Press, 588 p.

Becker, M.F., Bruce, B.W., Pope, L.M., and Andrews, W.J., 2002, Ground-water quality in the Central High Plains aquifer, Colorado, Kansas, New Mexico, Oklahoma, and Texas, 1999: U.S. Geological Survey Water-Resources Investigations Report 2002-4112, 64 p.

Bender, D.A., Zogorski, J.S., Halde, M.J., and Rowe, B.L., 1999, Selection procedure and salient information for volatile organic compounds emphasized in the National WaterQuality Assessment Program: U.S. Geological Survey Open-File Report 99-182, 32 p.

Berner, R.S., 1981, A new geochemical classification of sedimentary environments: Journal of Sedimentary petrology, v. 51 , no. 2 , p. $359-365$.

Bhattacharyya, G.K., and Johnson, R.A., 1977, Statistical concepts and methods: New York, John Wiley, 639 p. 
Bleed, A.S., and Flowerday, C.A, eds., 1989, An atlas of the Sand Hills ( $3 \mathrm{~d}$ ed.): Conservation and Survey Division, Institute of Agriculture and Natural Resources of the University of Nebraska, Resource Atlas no. 5b, 260 p.

Böhlke, J.K., 2002, Groundwater recharge and agricultural contamination: Hydrogeology Journal, v. 10, p. 153-179.

Brenton, R.W., and Arnett, T.L., 1993, Methods of analysis by the U.S. Geological Survey National Water Quality Laboratory-Determination of dissolved organic carbon by UV-promoted persulfate oxidation and infrared spectrometry: U.S. Geological Survey Open-File Report 92-480, 12 p.

Bruce, B.W., and Oelsner, G.P., 2001, Contrasting water quality from paired domestic/public supply wells, Central High Plains: Journal of the American Water Resources Association, v. 37, no. 5, p. 1389-1403.

Bushon, R.N., November 2003, Fecal indicator virus: U.S. Geological Survey Techniques of Water-Resources Investigations, book 9, chap. A7 (3d ed.), section 7.2, accessed February 14, 2005, from http://pubs.water.usgs.gov/twri9A/

Childress, C.J. Oblinger, Foreman, W.T., Connor, B.F., and Maloney, T.J., 1999, New reporting procedures based on long-term method detection levels and some considerations for interpretations of water-quality data provided by the U.S. Geological Survey National Water Quality Laboratory: U.S. Geological Survey Open-File Report 99-193, 19 p.

Clark, I.D., and Fritz, P., 1997, Environmental isotopes in hydrogeology: Boca Raton, CRC Press, 328 p.

Connor, B.F., Rose, D.L., Noriega, M.C., Murtagh, L., and Abney, S.R., 1998, Analysis by the U.S. Geological Survey National Water Quality Laboratory-Determination of 86 volatile organic compounds in water by gas chromatography/mass spectrometry, including detections less than reporting limits: U.S. Geological Survey Open-File Report 97-829, 78 p.

Dennehy, K.F., 2000, High Plains regional ground-water study: U.S. Geological Survey Fact Sheet FS-091-00, 6 p.

Dugan, J.T., and Zelt, R.B., 2000, Simulation and analysis of soil-water conditions in the Great Plains and adjacent areas, central United States, 1951-1980: U.S. Geological Survey Water-Supply Paper 2427, 81 p.

Elliott, L.F., McCalla, T.M., Mielke, L.N., and Travis, T.A., 1972, Ammonium, nitrate, and total nitrogen in the soil water of feedlot and field soil profiles: Applied Microbiology, v. 28, no. 4, p. 810-813.

Engberg, R.A., and Spalding, R.F., 1978, Groundwater quality atlas of Nebraska: Conservation and Survey Division of the University of Nebraska, Resource Atlas no. 3, 38 p.
Fahlquist, Lynne, 2003, Ground-water quality of the southern High Plains aquifer, Texas and New Mexico, 2001: U.S. Geological Survey Open-File Report 2003-345, 59 p.

Faires, L.M., 1993, Methods of analysis by the U.S. Geological Survey National Water Quality LaboratoryDetermination of metals in water by inductively coupled plasma-mass spectrometry: U.S. Geological Survey OpenFile Report 92-634, 28 p.

Fishman, M.J., ed., 1993, Methods of analysis by the U.S. Geological Survey National Water Quality LaboratoryDetermination of inorganic and organic constituents in water and fluvial sediments: U.S. Geological Survey OpenFile Report 93-125, 217 p.

Fishman, M.J., and Friedman, L.C., 1989, Methods for determination of inorganic substances in water and fluvial sediments: U.S. Geological Survey Techniques of WaterResources Investigations, book 5, chap. A1, 545 p.

Furlong, E.T., Anderson, B.D., Werner, S.L., Soliven, P.P., Coffey, L.J., and Burkhardt, M.R., 2001, Methods of analysis by the U.S. Geological Survey National Water Quality Laboratory-Determination of pesticides in water by graphitized carbon-based solid-phase extraction and high-performance liquid chromatography/mass spectrometry: U.S. Geological Survey Water-Resources Investigations Report 2001-4134, 73 p.

Garbarino, J.R., 1999, Methods of analysis by the U.S. Geological Survey National Water Quality LaboratoryDetermination of dissolved arsenic, boron, lithium, selenium, strontium, thallium, and vanadium using inductively coupled plasma-mass spectrometry: U.S. Geological Survey Open-File Report 99-093, 31 p.

Gilliom, R.J., Alexander, R.B., and Smith, R.A., 1985, Pesticides in the Nation's rivers, 1975-1980, and implications for future monitoring: U.S. Geological Survey WaterSupply Paper 2271, 26 p.

Gilliom, R.J., Hamilton, P.A., and Miller, T.L., 2001, The National Water-Quality Assessment Program-Entering a new decade of investigations: U.S. Geological Survey Fact Sheet 071-01, 6 p.

Gosselin, D.C., 1991, Bazile Triangle groundwater quality study: Nebraska Conservation and Survey Division of the University of Nebraska, Water-Supply Paper 68, 29 p.

Gosselin, D.C., Ayers, J.F., and Zhang, You-Kuan, 1994a, Modeling concentration variations in high-capacity wellsImplications for groundwater sampling: Water Resources Bulletin, v. 30, no. 4, p. 613-622.

Gosselin, D.C., Sibray, Steve, and Ayers, Jerry, 1994b, Geochemistry of K-rich alkaline lakes, western Sandhills, Nebraska, USA: Geochimica et Cosmochimica Acta, v. 58, no. 5, p. 1403-1418. 
Gosselin, D.C., Headrick, J., Chen, Xun-Hong, and Summerside, S., 1996, Domestic well-water quality in rural Nebraska: Conservation and Survey Division of the University of Nebraska, GIM-98, 4 p.

Gutentag, E.D., Heimes, F.J., Krothe, N.C., Luckey, R.R., and Weeks, J.B., 1984, Regional aquifer-system analysis of the High Plains aquifer in part of Colorado, Kansas, Nebraska, New Mexico, Oklahoma, South Dakota, Texas, and Wyoming-Geohydrology: U.S. Geological Survey Professional paper 1400-B, 63 p.

Harshman, E.N., 1972, Geology and uranium deposits, Shirley Basin area, Wyoming: U.S. Geological Survey Professional Paper 745, 82 p.

Helsel, D.R., 2005, Nondetects and data analysis-Statistics for censored environmental data: New Jersey, WileyInterscience, $250 \mathrm{p}$.

Helsel, D.R., and Hirsch, R.M., 1992, Statistical methods in water resources: Amsterdam, The Netherlands, Elsevier Science B.V., 529 p.

Helsel, D.R., and Cohn, T.A., 1988, Estimation of descriptive statistics for multiply censored water quality data: Water Resources Research, v. 24, no. 12, p. 1997-2004.

Hem, J.D., 1985, Study and interpretation of the chemical characteristics of natural water ( $3 \mathrm{~d}$ ed.): U.S. Geological Survey Water-Supply Paper 2254, 263 p.

Hergert, G.W., and Knudsen, D., 1977, Irrigation water quality criteria: accessed on January 9, 2005 at http://ianrpubs.unl.edu/water/g328.htm

Hoffman, G.J., undated, Water quality criteria for irrigation: accessed on January 9, 2005 at http://ianrpubs.unl.edu/ irrigation/ec $782 . \mathrm{htm}$

Johnson, C.R., 1960, Geology and ground water in the PlatteRepublican Rivers watershed and the Little Blue River Basin above Angus, Nebraska: U.S. Geological Survey Water-Supply Paper 1489, 142 p.

Kiely, Timothy, Donaldson, D., and Grube, A., 2004, Pesticide industry sales and usage, 2000 and 2001 market estimates: U.S. Environmental Protection Agency, Office of Pesticide Programs, Biological and Economic Analysis Division, EPA-733-R-04-001, 48 p.

Koterba, M.T., Wilde, F.D., and Lapham, W.W., 1995, Ground-water data-collection protocols and procedures for the National Water-Quality Assessment ProgramCollection and documentation of water-quality samples and related data: U.S. Geological Survey Open-File Report 95-399, 113 p.
Kuzelka, R.D., and Flowerday, C.A., 1993, Flat water-A history of Nebraska and its water: Conservation and Survey Division of the University of Nebraska, Resources Report 12, $291 \mathrm{p}$.

Lindley, C.E., Stewart, J.T., and Sandstrom, M.W., 1996, Determination of low concentrations of acetochlor in water by automated solid-phase extraction and gas chromatography with mass selective detection: Journal of Association of Official Analytical Chemists International, v. 79, no. 4, p. 962-966.

Litke, D.W., 2001, Historical water-quality data for the High Plains Regional Ground-Water Study area in Colorado, Kansas, Nebraska, New Mexico, Oklahoma, South Dakota, Texas, and Wyoming, 1930-98: U.S. Geological Survey Open-File Report 2000-4254, 65 p.

Madison, R.J., and Brunett, J.O., 1985, Overview of the occurrence of nitrate in ground water of the United States, in National water summary 1984-Hydrologic events, selected water-quality trends, and ground-water resources: U.S. Geological Survey Water-Supply Paper 2275, p. 93-105.

Madsen, J.E., Sandstrom, M.W., and Zaugg, S.D., 2003, Methods of analysis by the U.S. Geological Survey National Water Quality Laboratory-A method supplement for the determination of fipronil and degradates in water by gas chromatography/mass spectrometry: U.S. Geological Survey Open-File Report 2002-462, 11 p.

McLain, Betty, 1993, Methods of analysis by the U.S. Geological Survey National Water Quality LaboratoryDetermination of chromium in water by graphite furnace atomic absorption spectrophotometry: U.S. Geological Survey Open-File Report 93-449, 16 p.

McLean, J.E., and Bledsoe, B.E., 1992, Behavior of metals in soils: Environmental Protection Agency Ground Water Issue, EPA-540/S-92/018, 25 p.

McMahon, P.B., Böhlke, J.K., and Christenson, S.C., 2004a, Geochemistry, radiocarbon ages, and paleorecharge conditions along a transect in the central High Plains aquifer, southwestern Kansas, USA: Applied Geochemistry, v. 19, p. $1655-1686$.

McMahon, P.B., Böhlke, J.K., and Lehman, T.M., 2004b, Vertical gradients in water chemistry and age in the Southern High Plains aquifer, Texas, 2002: U.S. Geological Survey Scientific Investigations Report 2004-5053, 53 p.

Moran, M.J., Lapham, W.W., Rowe, B.L., and Zogorski, J.S., 2002, Occurrence and status of volatile organic compounds in ground water from rural, untreated, self-supplied domestic wells in the United States, 1986-99: U.S. Geological Survey Water Resources Investigations Report 2002-4085, 51 p. 
Morrow, W.S., 2001, Uranium and radon in ground water in the lower Illinois River Basin: U.S. Geological Survey Water-Resources Investigations Report 2001-4056, 29 p.

Mueller, D.K., and Helsel, D.R., 1996, Nutrients in the Nation's waters-Too much of a good thing?: U.S. Geological Survey Circular 1136, 24 p.

Naftz, D.L., 1996, Uraniferous waters from irrigated lands in the Western United States: USA/CIS Joint Conference on Environmental Hydrology and Hydrogeology, in Third USA/CIS joint conference on Environmental hydrology and hydrogeology_-Water: Sustaining a critical resource, 1996, p. 215-223.

Naftz, D.L., Fuller, C.C., Davis, J.A., Morrison, S.J., Feltcorn, E.M., Freethey, G.W., Rowland, R.C., Wilkowske, C., and Piana, M., 2002, Field demonstration of three permeable reactive barriers to control uranium contamination, in Naftz, David, Morrison, S.J., Fuller, C.C., and Davis, J.A., eds., Handbook of groundwater remediation using permeable reactive barriers-Applications to radionuclides, trace metals, and nutrients: San Diego, Calif., Academic Press, 539 p. (ISBN 0-12-513563-7)

Nash, K.G., 1978, Geochemistry of selected closed basin lakes in Sheridan County, Nebraska: Lincoln, University of Nebraska Master's thesis, 93 p.

National Atmospheric Deposition Program, 2000, Nitrogen in the Nation's rain: National Atmospheric Deposition Program Brochure 2000-01a, 13 p.

National Center for Food and Agricultural Policy, 1997, National pesticide use database, National Center for Food and Agricultural Policy (NCFAP): accessed December 29, 2004, at http://www.ncfap.org/database/default.php

Patton, C.J., and Kryskalla, J.R., 2003, Methods of analysis by the U.S. Geological Survey National Water Quality Laboratory-Evaluation of alkaline persulfate digestion as an alternative to Kjeldahl digestion for determination of total and dissolved nitrogen and phosphorus in water: U.S. Geological Survey Water-Resources Investigations Report 2003-4174, 33 p.

Rankama, Kalervo, and Sahama, T.H., 1950, Geochemistry: Chicago, The University of Chicago Press, 911 p.

Richmond, G.M., Swinehart, J.B., Dreeszen, V.H., Tipton, M.J., Richard, B., Steece, F.V., Hallberg, G.R., and Goebel, J.E., 1994, Quaternary geologic map of the Platte River $4^{\circ} \times 6^{\circ}$ Quadrangle, United States: U.S. Geological Survey Map Report I-1420 (NK-14), 1 plate.

Schwarz, G.E., and Alexander, R.B., 1995, State soil geographic (STATSGO) data base for the conterminous United States: U.S. Geological Survey Open-File Report 95-449, digital data, available at http://water.usgs.gov/GIS/metadata/ usgswrd/XML/ussoils.xml
Scott, J.C., 1990, Computerized stratified random siteselection approaches for design of a ground-water-quality sampling network: U.S. Geological Survey Water-Resources Investigations Report 90-4101, 109 p.

Smedley, P.L., and Kinniburgh, D.G., 2002, A review of the source, behaviour, and distribution of arsenic in natural waters: Applied Geochemistry, v. 17, p. 517-568.

Snow, D.D., and Spalding, R.F., 1994, Uranium isotopes in the Platte River drainage basin of the North American High Plains Region: Applied Geochemistry, v. 9, p. 271-278.

Spalding, R.F., and Sackett, W.M., 1972, Uranium in runoff from the Gulf of Mexico distributive province-Anomalous concentrations: Science, v. 175, p. 629-631.

Stumm, Werner, and Morgan, J.J., 1996, Aquatic chemistry (3d ed.): New York, Wiley, 536 p.

Swinehart, J.B., and Diffendal, R.F., Jr., 1989, Geology in Bleed, A.S., and Flowerday, C.A, eds., 1989, An atlas of the Sand Hills ( $3 \mathrm{~d}$ ed.): Conservation and Survey Division of the University of Nebraska, Resource Atlas no. 5b, p. 29-42.

Swinehart, J.B., and Diffendal, R.F., Jr., 1997, Geologic map of the Scottsbluff $1^{\circ} \times 2^{\circ}$ quadrangle, Nebraska and Colorado: U.S. Geological Survey Map Report I-2545, 1 plate.

Swinehart, J.B., Souders, V.L., DeGraw, H.M., and Diffendal, R.F., Jr., 1985, Cenozoic paleogeography of western Nebraska, in Flores, R.M., and Kaplan, S.S., eds., Cenozoic paleogeography of west-central United States: Proceedings of Rocky Mountain Paleogeography Symposium 3, Denver, Colorado, 1985, p. 209-229.

Thatcher, L.L., 1962, The distribution of tritium fallout in precipitation over North America: Bulletin of the International Association of Scientific Hydrology, v. 7, p. 48-58.

Thatcher, L.L., Janzer, V.J., and Edwards, K.W., 1977, Methods for determination of radioactive substances in water and fluvial sediments: U.S. Geological Survey Techniques of Water-Resources Investigations, book 5, chap. A5, 95 p.

Thelin, G.P., and Heimes, F.J., 1987, Mapping irrigated cropland from Landsat data for determination of water use from the High Plains aquifer, in parts of Colorado, Kansas, Nebraska, New Mexico, Oklahoma, South Dakota, Texas, and Wyoming: U.S. Geological Survey Professional Paper 1400-C, 38 p.

U.S. Department of Agriculture, 1994, State soil geographic (STATSGO) database for Nebraska, digital data, available at http://www.ncgc.nrcs.usda.gov/products/datasets/statsgo/ index.html

U.S. Department of Agriculture, 1997, Census of agriculture: accessed March 4, 2005 at URL http://www.nass.usda.gov/ census/ 
U.S. Department of the Interior, 1998, Guidelines for the interpretation of the biological effects of selected constituents in biota, water, and sediment-Selenium: accessed January 11, 2006 at URL http://www.usbr.gov/niwqp/ guidelines/Selenium.pdf

U.S. Environmental Protection Agency, 1983, Methods for chemical analysis of water and wastes: U.S. Environmental Protection Agency Report EPA/600/4-79/020.

U.S. Environmental Protection Agency, 1994, Is your drinking water safe?: U.S. Environmental Protection Agency Report EPA 810-F-94-002, Office of Water, Washington, D.C., May, 19 p.

U.S. Environmental Protection Agency, 1996, Drinking water regulations and health advisories: Washington, D.C., U.S. Environmental Protection Agency Report EPA 822-B-96-002, October, 13 p.

U.S. Environmental Protection Agency, 1999, Understanding the Safe Drinking Water Act: Washington, D.C., U.S. Environmental Protection Agency Report EPA 810-F-99-008, $3 \mathrm{p}$.

U.S. Environmental Protection Agency, 2000, Method 1601Male-specific $(\mathrm{F}+)$ and somatic coliphage in water by two-step enrichment procedure-April 2000-Draft: Washington, D.C., U.S. Environmental Protection Agency Report EPA 821-R-00-009.

U.S. Environmental Protection Agency, 2002, Method 1604Total coliforms and Escherichia coli in water by membrane filtration using a simultaneous detection technique (MI medium): Washington D.C., U.S. Environmental Protection Agency Report EPA 821-R-02-024, 14 p.

U.S. Environmental Protection Agency, 2003, EPA Assessment of risks from radon in homes: Washington D.C., Office of Radiation and Indoor Air, U.S. Environmental Protection Agency Report EPA 402-R-03-003, $88 \mathrm{p}$.

U.S. Environmental Protection Agency, 2004, Current drinking water standards: accessed (2004), at URL http://www.epa.gov/safewater/standards.html

U.S. Geological Survey, 1964, Mineral and water resources of South Dakota: U.S. Congress, 88th, 2d Session, Interior and Insular Affairs Committee Print, 295 p.

U.S. Geological Survey, 1975, Mineral and water resources of South Dakota: U.S. Congress, 94th, 1st Session, Interior and Insular Affairs Committee Print, 313 p.

U.S. Geological Survey, 1992, National land characteristics data set: accessed March 3, 2005 at URL http://edc.usgs.gov/ products/landcover/nlcd.html
U.S. Geological Survey, variously dated, National field manual for the collection of water-quality data: U.S. Geological Survey Techniques of Water-Resources Investigations, book 9, chaps. A1-A9, available online at http://pubs.water.usgs.gov/ twri9A

Unterweger, M.P., Coursey, B.M., Shima, F.J., and Mann, W.B., 1980, Preparation and calibration of the 1978 National Bureau of Standards tritiated water standards: International Journal of Applied Radiation and Isotopes, v. 31, p. 611-614.

Verstraeten, I.M., Steele, G.V., Cannia, J.C., Hitch, D.E., Scripter, K.G., Böhlke, J.K., Kraemer, T.F., and Stanton, J.S., 2001, Interaction of surface water and ground water in the Dutch Flats area, western Nebraska, 1995-99: U.S. Geological Survey Water-Resources Investigations Report 2001-4070, 56 p.

Waite, H.A., and others, 1949, Progress report on the geology and ground-water hydrology of the lower Platte River Valley, Nebraska: U.S. Geological Survey Circular 20, $211 \mathrm{p}$.

Wauchope, R.D., Buttler, T.M., Hornsby, A.G., AugustijnBeckers, P.M., and Burt, J.P., 1992, The SCS/ARS/CES pesticide properties database for environmental decision making: Reviews of Environmental Contamination and Toxicology, v. 123, p. 1-155.

Welch, A.H., Westjohn, D.B., Helsel, D.R., and Wanty, R.B., 2000, Arsenic in ground water of the United StatesOccurrence and geochemistry: Ground Water, v. 38, no. 4, p. 589-604.

Werner, S.L., Burkhardt, M.R., and DeRusseau, S.N., 1996, Methods of analysis by the U.S. Geological Survey National Water Quality Laboratory—Determination of pesticides in water by Carbopak-B solid-phase extraction and highperformance liquid chromatography: U.S. Geological Survey Open-File Report 96-216, 42 p.

White, D.E., and Waring, G.A., 1963, Volcanic emanations, in Data of geochemistry (6th ed.): U.S. Geological Survey Professional Paper 440-K, p. K1-K29.

Wilcoxon, Frank, 1945, Individual comparisons by ranking methods: Biometrics, v. 1, p. 80-83.

Zaugg, S.D., Sandstrom, M.W., Smith, S.G., and Fehlberg, K.M., 1995, Methods of analysis by the U.S. Geological Survey National Water Quality Laboratory-Determination of pesticides in water by $\mathrm{C}-18$ solid-phase extraction and capillary-column gas chromatography/mass spectrometry with selected-ion monitoring: U.S. Geological Survey Open-File Report 95-181, 60 p. 


\section{Appendixes}


Appendix 1. Selected well-construction information for wells sampled in the northern High Plains aquifer, 1997, $2002-04$.

[Depths are in feet below land surface. OGAL, Ogallala Formation; EAST, Eastern Nebraska; PLAT, Platte River Valley; SAND, Sand Hills; E, estimated]

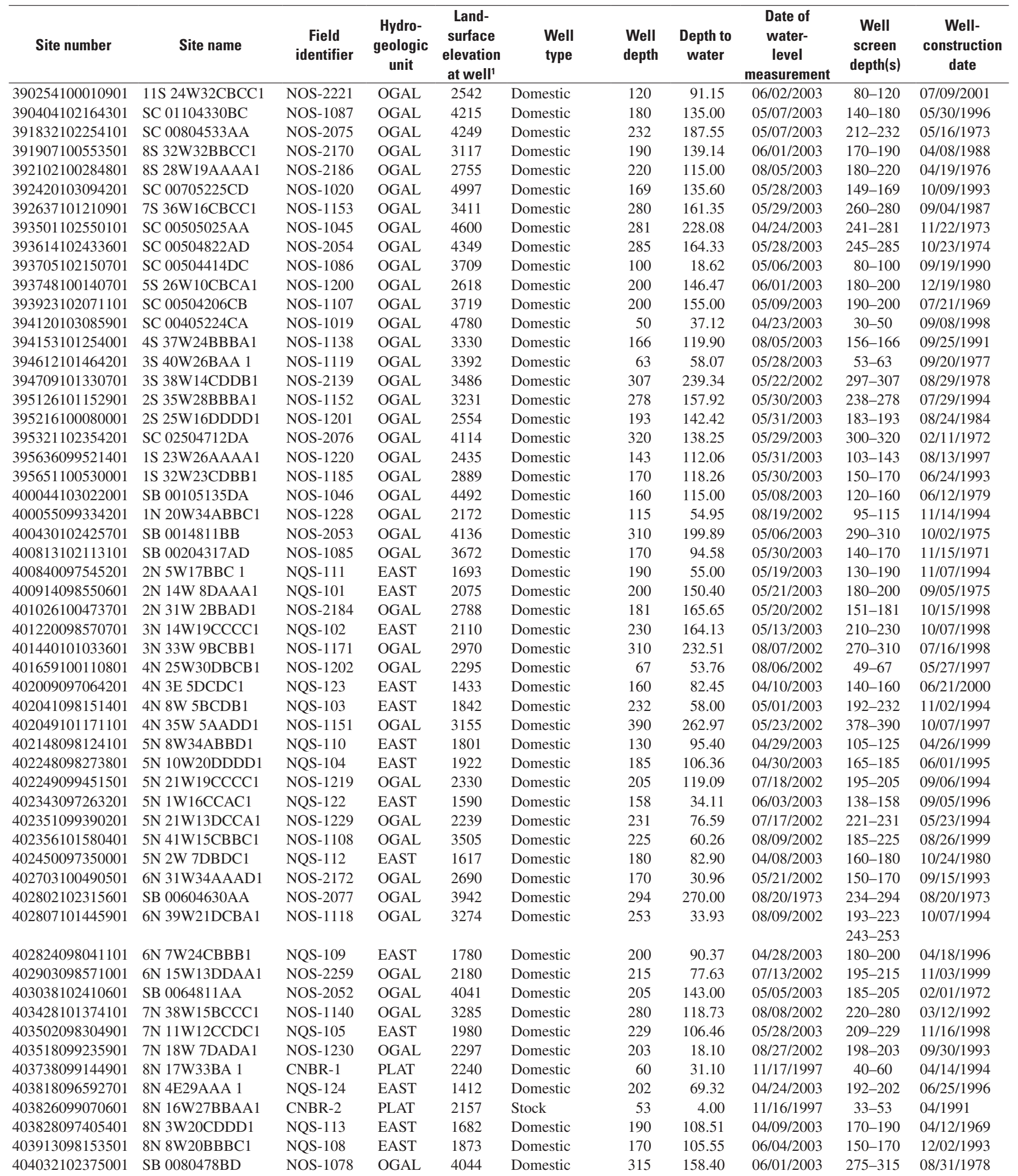


Appendix 1. Selected well-construction information for wells sampled in the northern High Plains aquifer, 1997, 2002-04.-Continued

[Depths are in feet below land surface. OGAL, Ogallala Formation; EAST, Eastern Nebraska; PLAT, Platte River Valley; SAND, Sand Hills; E, estimated]

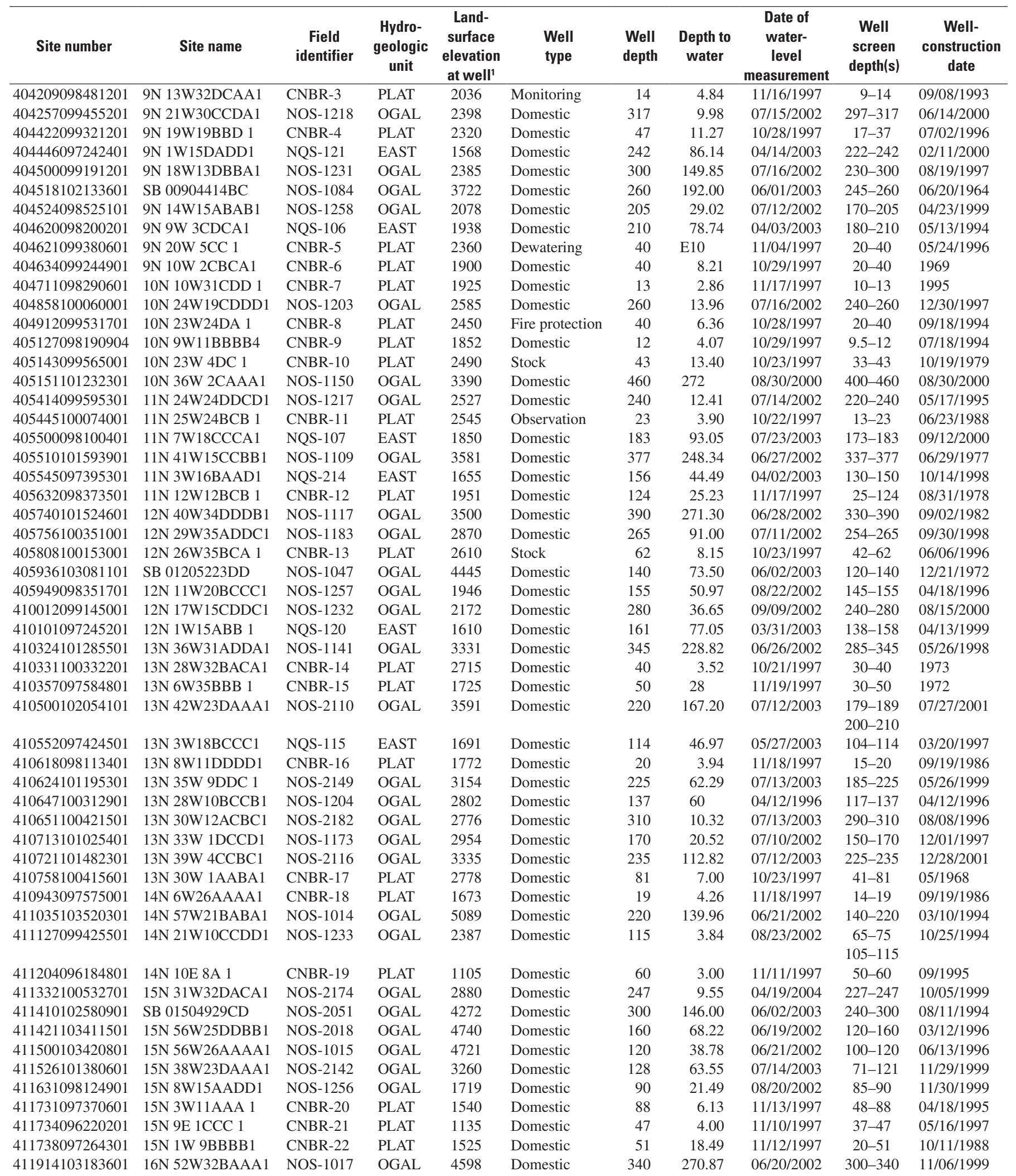


Appendix 1. Selected well-construction information for wells sampled in the northern High Plains aquifer, 1997, 2002-04.-Continued

[Depths are in feet below land surface. OGAL, Ogallala Formation; EAST, Eastern Nebraska; PLAT, Platte River Valley; SAND, Sand Hills; E, estimated]

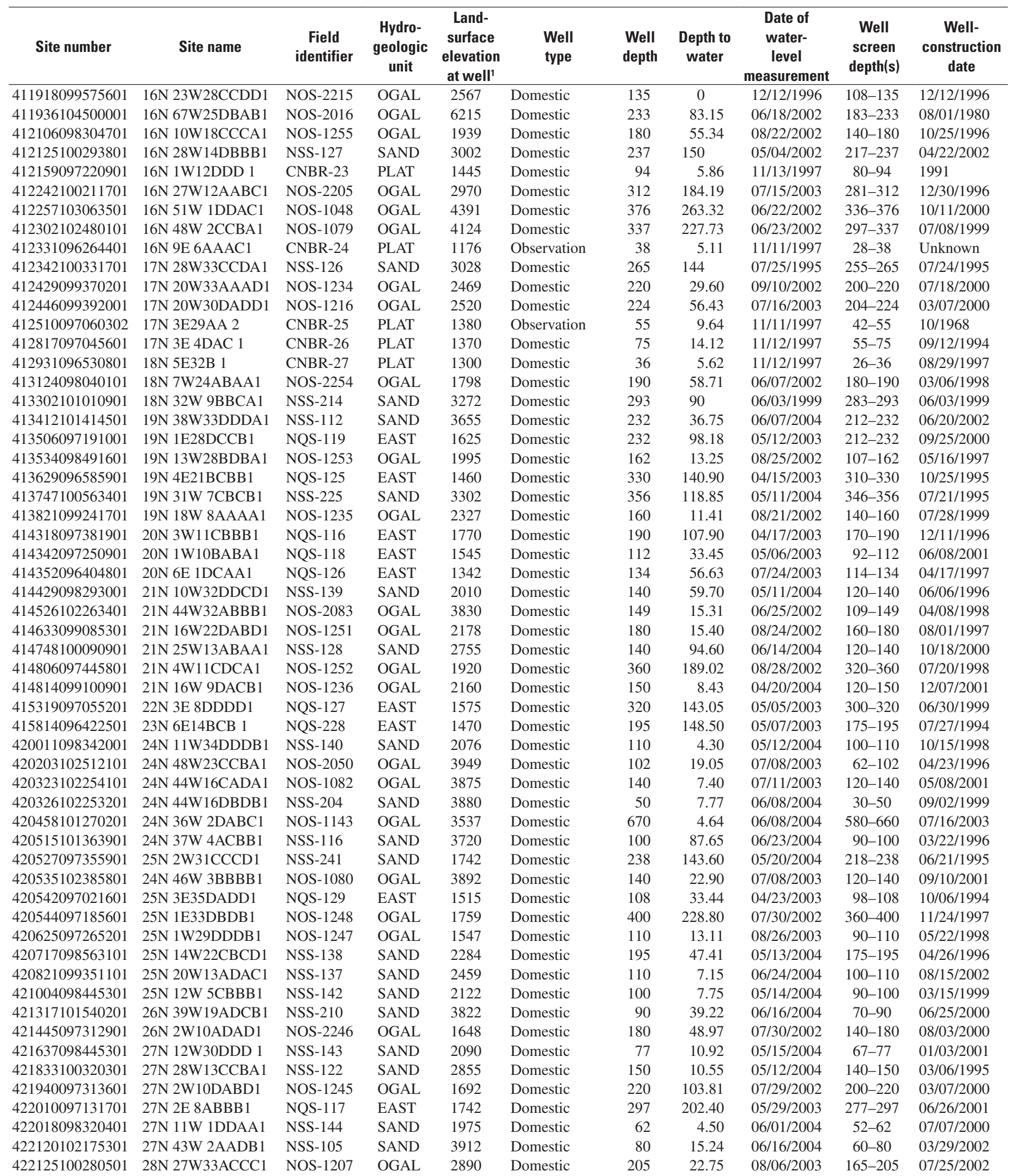


Appendix 1. Selected well-construction information for wells sampled in the northern High Plains aquifer, 1997, 2002-04.-Continued

[Depths are in feet below land surface. OGAL, Ogallala Formation; EAST, Eastern Nebraska; PLAT, Platte River Valley; SAND, Sand Hills; E, estimated]

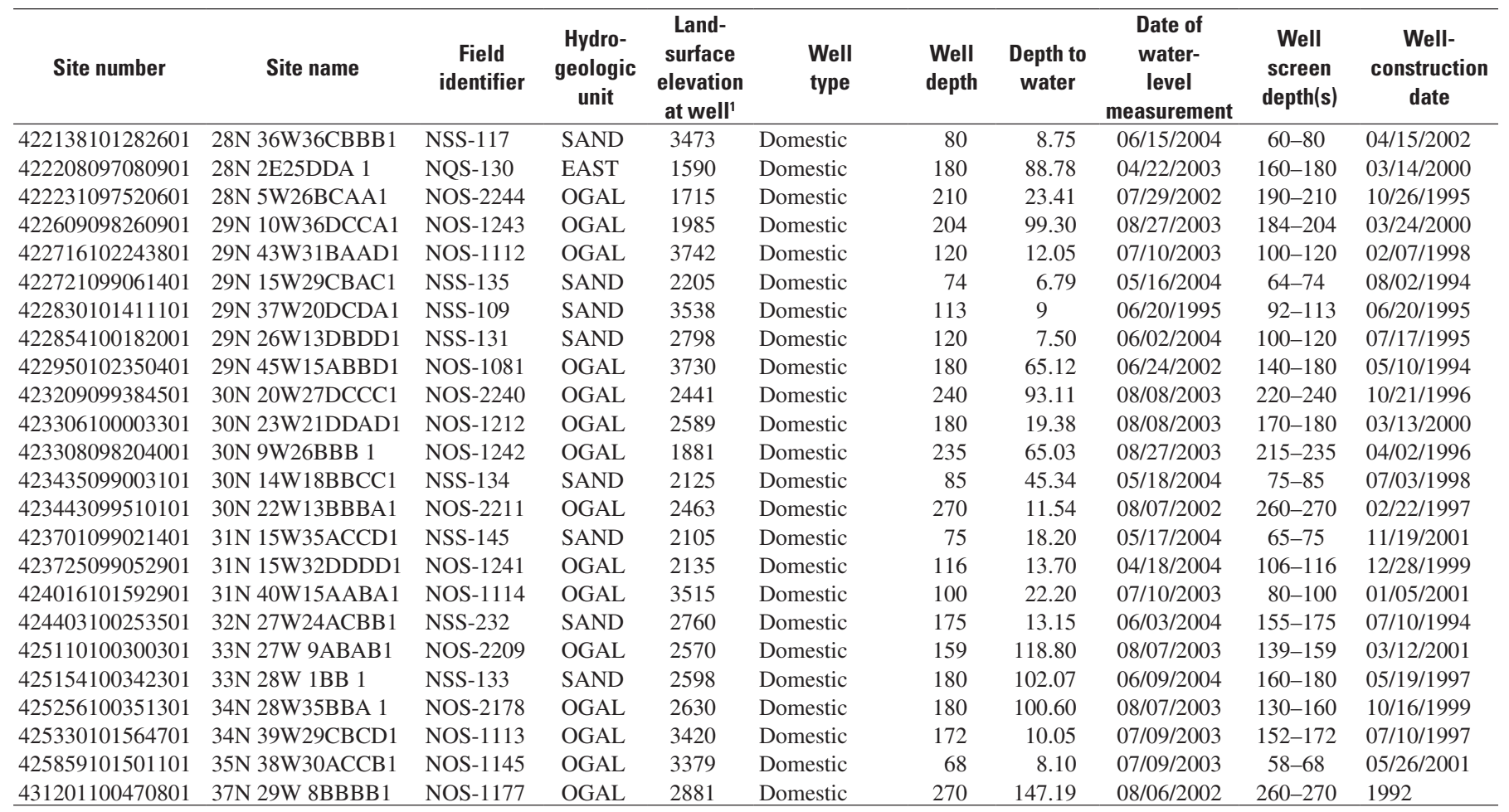

${ }^{1}$ Vertical coordinate information is referenced to the North American Vertical Datum of 1929 (NGVD 29). 
Appendix 2. Pesticides analyzed in ground-water samples collected from the northern High Plains aquifer, 1997, 2002-04.

[Concentrations are in micrograms per liter. USGS, U.S. Geological Survey; CAS, Chemical Abstracts Service; USEPA, U.S. Environmental Protection Agency; --, no data; LTHA, Lifetime Health Advisory; MCL, Maximum Contaminant Level; NA, not analyzed]

\begin{tabular}{|c|c|c|c|c|c|c|c|}
\hline Pesticide name & $\begin{array}{c}\text { USGS } \\
\text { parameter } \\
\text { code }\end{array}$ & CAS number & $\begin{array}{l}\text { Number of } \\
\text { samples } \\
\text { analyzed }\end{array}$ & $\begin{array}{c}\text { Highest } \\
\text { laboratory } \\
\text { reporting level } \\
(\mathrm{LRL})^{3}\end{array}$ & $\begin{array}{c}\text { Mean } \\
\text { field-matrix } \\
\text { spike recovery } \\
\text { (in percent) }^{4}\end{array}$ & $\begin{array}{c}\text { Pesticide } \\
\text { type(s) }\end{array}$ & $\begin{array}{c}\text { USEPA } \\
\text { drinking-water } \\
\text { standard / type } \\
\text { of standard }^{5}\end{array}$ \\
\hline $2,4,5-\mathrm{T}$ & 39742 & $93-76-5$ & 27 & 0.04 & 84.6 & Herbicide & 70 / LTHA \\
\hline 2,4-D methyl ester & 50470 & $1928-38-7$ & 162 & 0.009 & 72.5 & Herbicide & -- \\
\hline $2,4-\mathrm{D}$ & 39732 & $94-75-7$ & 189 & 0.04 & 111.0 & Herbicide & 70 / MCL \\
\hline Deethylatrazine (CIAT) $)^{2}$ & 04040 & $6190-65-4$ & 192 & 0.006 & 52.5 & Degradate & -- \\
\hline 2Methyl 4,6-dinitrophenol (DNOC) & 49299 & $534-52-1$ & 27 & 0.04 & 61.3 & Herbicide & -- \\
\hline Deisopropylatrazine $(\mathrm{CEAT})^{2}$ & 04038 & $1007-28-9$ & 162 & 0.04 & 71.7 & Degradate & -- \\
\hline 2-Hydroxyatrazine $(\mathrm{OIET})^{2}$ & 50355 & $2163-68-0$ & 162 & 0.008 & NA & Degradate & -- \\
\hline 3-Hydroxy carbofuran & 49308 & $16655-82-6$ & 189 & 0.01 & 82.9 & Degradate & -- \\
\hline 3-Ketocarbofuran ${ }^{2}$ & 50295 & $16709-30-1$ & 162 & 2 & 0.0 & Degradate & -- \\
\hline Aldicarb sulfoxide ${ }^{2}$ & 49314 & $1646-87-3$ & 189 & 0.02 & 43.2 & Degradate & $4 / \mathrm{MCL}$ \\
\hline Aldicarb $^{2}$ & 49312 & $116-06-3$ & 189 & 0.04 & 21.4 & Insecticide & $3 / \mathrm{MCL}$ \\
\hline Alpha-HCH & 34253 & $319-84-6$ & 191 & 0.005 & 102.9 & $\begin{array}{l}\text { Insecticide / } \\
\text { Degradate }\end{array}$ & -- \\
\hline Atrazine & 39632 & $1912-24-9$ & 192 & 0.01 & 108.1 & Herbicide & $3 / \mathrm{MCL}$ \\
\hline Azinphos-methyl $^{2}$ & 82686 & $86-50-0$ & 191 & 0.050 & 91.3 & Insecticide & -- \\
\hline Bendiocarb & 50299 & $22781-23-3$ & 162 & 0.03 & 63.0 & Insecticide & -- \\
\hline Benfluralin & 82673 & $1861-40-1$ & 191 & 0.010 & 81.7 & Herbicide & -- \\
\hline Benomyl & 50300 & $17804-35-2$ & 162 & 0.004 & 59.5 & Fungicide & -- \\
\hline Bensulfuron & 61693 & $83055-99-6$ & 162 & 0.02 & 107.4 & Herbicide & -- \\
\hline Bentazon $^{2}$ & 38711 & $25057-89-0$ & 189 & 0.01 & 37.8 & Herbicide & 200 / LTHA \\
\hline Chlorothalonil $^{2}$ & 49306 & $1897-45-6$ & 189 & 0.04 & 16.3 & Fungicide & -- \\
\hline Chlorpyrifos & 38933 & $2921-88-2$ & 191 & 0.005 & 94.4 & Insecticide & 20 / LTHA \\
\hline cis-Permethrin & 82687 & $54774-45-7$ & 191 & 0.006 & 63.4 & Insecticide & -- \\
\hline Clopyralid & 49305 & $1702-17-6$ & 189 & 0.05 & 66.0 & Herbicide & -- \\
\hline Cyanazine & 04041 & $21725-46-2$ & 191 & 0.018 & 101.8 & Herbicide & 1 / LTHA \\
\hline Cycloate $^{2}$ & 04031 & $1134-23-2$ & 162 & 0.01 & 55.1 & Herbicide & -- \\
\hline Dacthal monoacid & 49304 & $887-54-7$ & 189 & 0.02 & 91.8 & Degradate & -- \\
\hline DCPA & 82682 & $1861-32-1$ & 189 & 0.003 & 102.4 & Herbicide & 70 / LTHA \\
\hline Desulfinylfipronil & 62170 & -- & 113 & 0.012 & 116.2 & Degradate & -- \\
\hline Diazinon & 39572 & $333-41-5$ & 191 & 0.005 & 106.2 & Insecticide & 0.6 / LTHA \\
\hline Dicamba & 38442 & $1918-00-9$ & 189 & 0.04 & 87.7 & Herbicide & -- \\
\hline Dichlobenil & 49303 & $1194-65-6$ & 27 & 0.02 & $\mathbf{5 7 . 3}$ & Herbicide & -- \\
\hline Dichlorprop & 49302 & $120-36-5$ & 189 & 0.03 & 85.0 & Herbicide & -- \\
\hline Dieldrin & 39381 & $60-57-1$ & 191 & 0.009 & 95.7 & Insecticide & -- \\
\hline Dinoseb & 49301 & $88-85-7$ & 189 & 0.04 & 77.4 & Herbicide & 7 / MCL \\
\hline Diphenamid & 04033 & $957-51-7$ & 162 & 0.03 & 90.2 & Herbicide & 200 / MCL \\
\hline Disulfoton & 82677 & 298-04-4 & 191 & 0.02 & 56.8 & Insecticide & 0.3 / LTHA \\
\hline
\end{tabular}


Appendix 2. Pesticides analyzed in ground-water samples collected from the northern High Plains aquifer, 1997, 2002-04.-Continued

[Concentrations are in micrograms per liter. USGS, U.S. Geological Survey; CAS, Chemical Abstracts Service; USEPA, U.S. Environmental Protection Agency; --, no data; LTHA, Lifetime Health Advisory; MCL, Maximum Contaminant Level; NA, not analyzed]

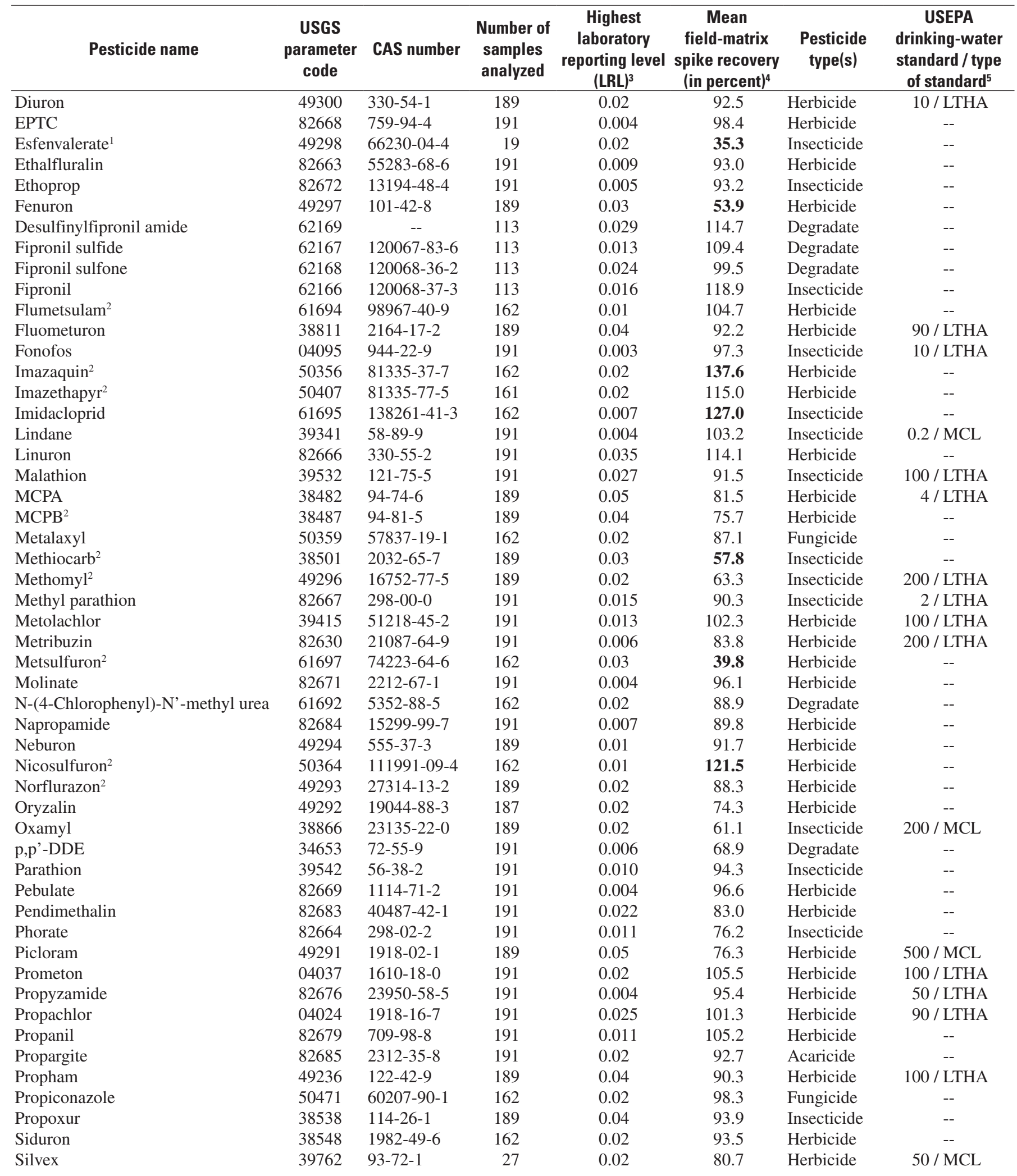


Appendix 2. Pesticides analyzed in ground-water samples collected from the northern High Plains aquifer, 1997, 2002-04.-Continued

[Concentrations are in micrograms per liter. USGS, U.S. Geological Survey; CAS, Chemical Abstracts Service; USEPA, U.S. Environmental Protection Agency; --, no data; LTHA, Lifetime Health Advisory; MCL, Maximum Contaminant Level; NA, not analyzed]

\begin{tabular}{|c|c|c|c|c|c|c|c|}
\hline Pesticide name & $\begin{array}{c}\text { USGS } \\
\text { parameter } \\
\text { code }\end{array}$ & CAS number & $\begin{array}{l}\text { Number of } \\
\text { samples } \\
\text { analyzed }\end{array}$ & $\begin{array}{c}\text { Highest } \\
\text { laboratory } \\
\text { reporting level } \\
\text { (LRL) }\end{array}$ & $\begin{array}{c}\text { Mean } \\
\text { field-matrix } \\
\text { spike recovery } \\
\text { (in percent) }^{4}\end{array}$ & $\begin{array}{c}\text { Pesticide } \\
\text { type(s) }\end{array}$ & $\begin{array}{c}\text { USEPA } \\
\text { drinking-water } \\
\text { standard / type } \\
\text { of standard }{ }^{5}\end{array}$ \\
\hline Sulfometuron $^{2}$ & 50337 & $74222-97-2$ & 162 & 0.009 & 104.2 & Herbicide & -- \\
\hline Tebuthiuron & 82670 & $34014-18-1$ & 192 & 0.02 & 113.4 & Herbicide & 500 / LTHA \\
\hline Terbacil & 82665 & $5902-51-2$ & 191 & 0.034 & 89.2 & Herbicide & 90 / LTHA \\
\hline Triallate & 82678 & $2303-17-5$ & 191 & 0.002 & 101.6 & Herbicide & -- \\
\hline Triclopyr & 49235 & $55335-06-3$ & 189 & 0.05 & 91.3 & Herbicide & -- \\
\hline Trifluralin & 82661 & $1582-09-8$ & 191 & 0.009 & 82.0 & Herbicide & 5 / LTHA \\
\hline
\end{tabular}

${ }^{1}$ No longer analyzed as part of this method as of 12/15/1997 due to unacceptable method performance.

${ }^{2}$ These pesticides are qualitatively identified and reported with an E (estimated value) because of problems with gas chromatography or extraction or do not meet laboratory method performance criteria (Zaugg and others, 1995).

${ }^{3}$ Source: U.S. Geological Survey National Water Quality Laboratory.

${ }^{4}$ Values in bold indicate mean percent recovery of compound did not fall within the acceptable performance range (60 to 120 percent).

${ }^{5}$ Source: U.S. Environmental Protection Agency, 2004. 
Appendix 3. Volatile organic compounds analyzed in ground-water samples collected from the northern High Plains aquifer, 1997, 2002-04.

[Concentrations are in micrograms per liter. USGS, U.S. Geological Survey; CAS, Chemical Abstracts Service; USEPA, U.S. Environmental Protection Agency; LTHA, Lifetime Health Advisory; MCL, Maximum Contaminant Level; --, no data]

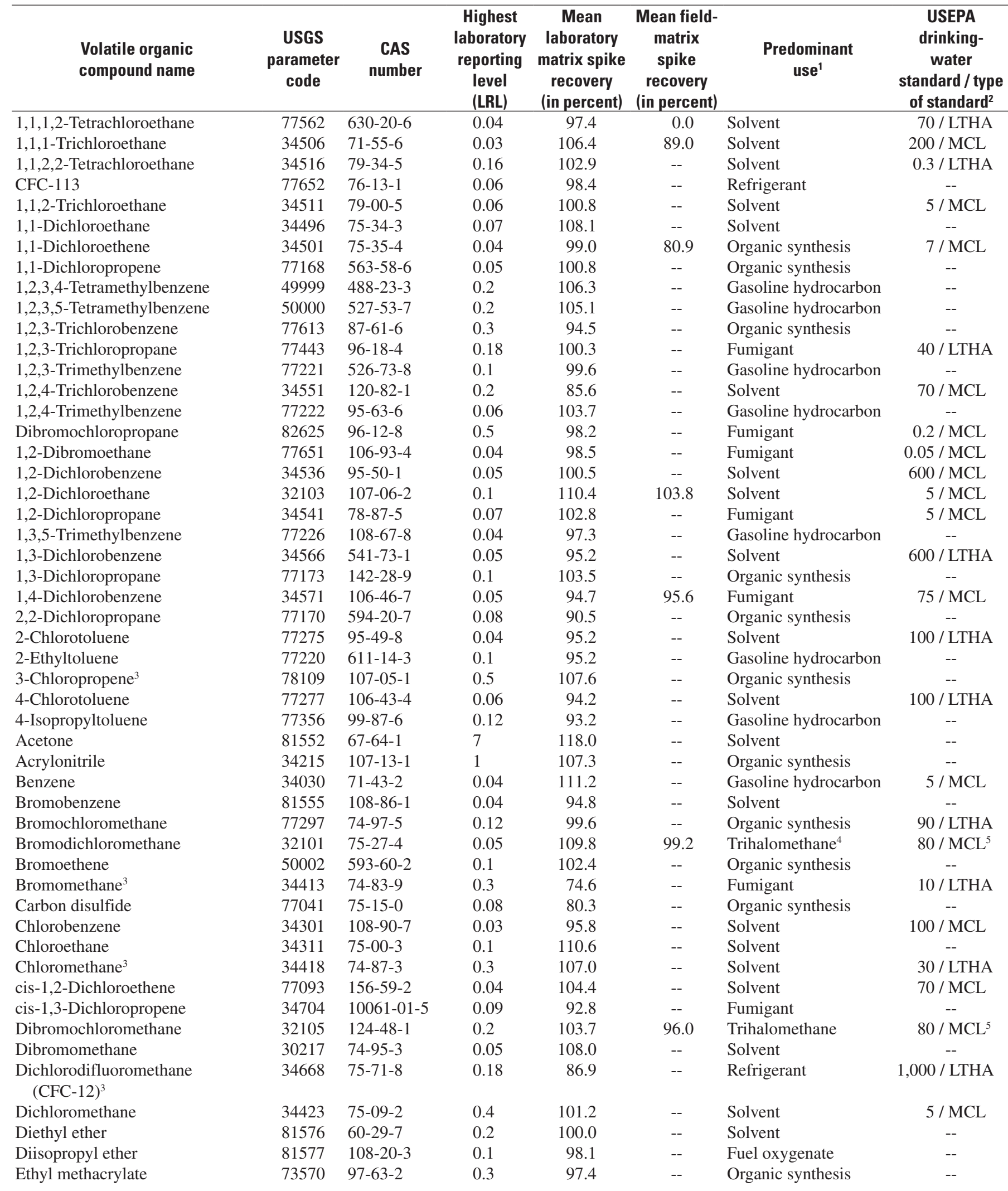


Appendix 3. Volatile organic compounds analyzed in ground-water samples collected from the northern High Plains aquifer, 1997, 2002-04.-Continued

[Concentrations are in micrograms per liter. USGS, U.S. Geological Survey; CAS, Chemical Abstracts Service; USEPA, U.S. Environmental Protection Agency; LTHA, Lifetime Health Advisory; MCL, Maximum Contaminant Level; --, no data]

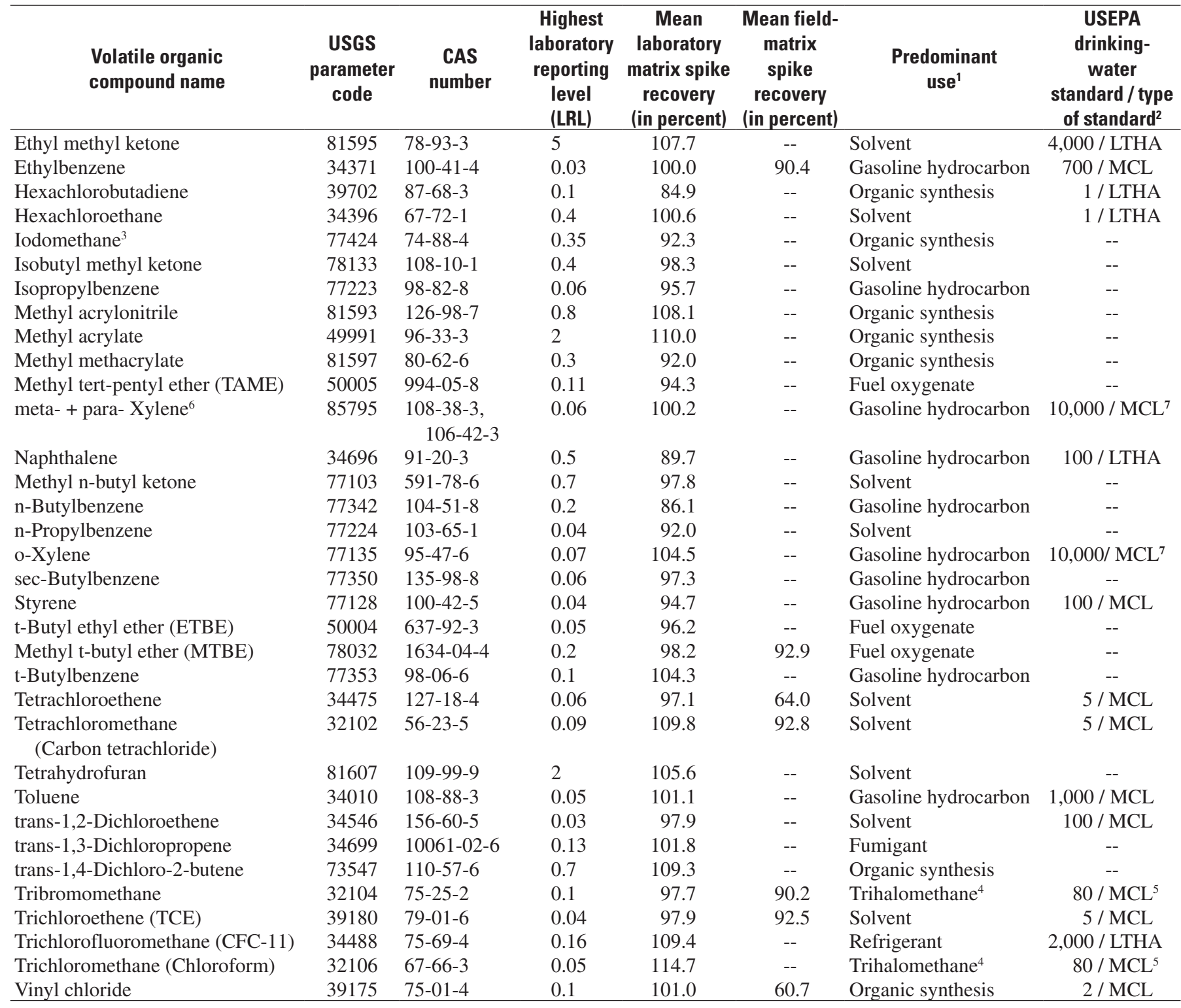

${ }^{1}$ Source: David Bender, U.S. Geological Survey, written commun., 2005.

${ }^{2}$ Source: U.S. Environmental Protection Agency, 2004.

${ }^{3}$ These VOCs are qualitatively identified and reported with an E (estimated value) because of excessive standard deviations (Connor and others, 1998).

${ }^{4}$ Although classified as a trihalomethane, this compound is used predominantly as a solvent.

${ }^{5} \mathrm{MCL}$ is for sum of all trihalomethanes.

${ }^{6}$ Analytical result reported as the sum of concentrations for these two compounds by the U.S. Geological Survey National Water Quality Laboratory.

${ }^{7} \mathrm{MCL}$ is for sum of all xylenes. 


\section{Appendix 4. Description of CD-ROM contents.}

The northern High Plains ground-water quality database is on the CD-ROM in Microsoft Access and tab-delimited ASCII flat files. The MS Access 2000 database file requires the user to have a copy of MS Access 2000 available on their computer. It can be opened by double-clicking on the data file name. ASCII files can be used as they are or loaded into any database software that reads standard ASCII format.

The database includes results from samples collected in four hydrogeologic units (Ogallala Formation,
Eastern Nebraska, Sand Hills, and Platte River Valley). There are three primary linked tables (see below) contained in the database (SAMPLES, QW_RESULTS, and PARAMETERS). The tables prefixed with "tbl" are lookup tables that contain the meanings of some of the codes used in the database. Also included are 10 tables prefixed with "NHP" that represent some standard result tables from the database for the major constituent groups. 